\title{
Geographical Concentration and Editorial Favoritism within the Field of Laboratory Experimental Economics
}

\author{
Citation for published version (APA):
}

Cloos, J., Greiff, M., \& Rusch, H. (2019). Geographical Concentration and Editorial Favoritism within the Field of Laboratory Experimental Economics. Maastricht University, Graduate School of Business and Economics. GSBE Research Memoranda No. 029 https://doi.org/10.26481/umagsb.2019029

Document status and date:

Published: 16/12/2019

DOI:

10.26481/umagsb.2019029

Document Version:

Publisher's PDF, also known as Version of record

\section{Please check the document version of this publication:}

- A submitted manuscript is the version of the article upon submission and before peer-review. There can be important differences between the submitted version and the official published version of record. People interested in the research are advised to contact the author for the final version of the publication, or visit the DOI to the publisher's website.

- The final author version and the galley proof are versions of the publication after peer review.

- The final published version features the final layout of the paper including the volume, issue and page numbers.

Link to publication

\footnotetext{
General rights rights.

- You may freely distribute the URL identifying the publication in the public portal. please follow below link for the End User Agreement:

www.umlib.nl/taverne-license

Take down policy

If you believe that this document breaches copyright please contact us at:

repository@maastrichtuniversity.nl

providing details and we will investigate your claim.
}

Copyright and moral rights for the publications made accessible in the public portal are retained by the authors and/or other copyright owners and it is a condition of accessing publications that users recognise and abide by the legal requirements associated with these

- Users may download and print one copy of any publication from the public portal for the purpose of private study or research.

- You may not further distribute the material or use it for any profit-making activity or commercial gain

If the publication is distributed under the terms of Article $25 \mathrm{fa}$ of the Dutch Copyright Act, indicated by the "Taverne" license above, 
Janis Cloos, Matthias Greiff, Hannes Rusch

Geographical Concentration and Editorial Favoritism within the Field of Laboratory Experimental Economics

RM/19/029

\section{GSBE}

Maastricht University School of Business and Economics

Graduate School of Business and Economics

\section{P.O Box 616}

NL- 6200 MD Maastricht

The Netherlands 


\title{
Geographical Concentration and Editorial Favoritism within the Field of Laboratory Experimental Economics
}

\author{
Janis Cloos, Matthias Greiff and Hannes Rusch ${ }^{\bowtie}$
}

This version: December 12, 2019

\begin{abstract}
We examine geographical concentration, scientific quality, and editorial favoritism in the field of experimental economics. We use a novel data set containing all original research papers $(N=583)$ that exclusively used laboratory experiments for data generation and were published in the American Economic Review, Experimental Economics or the Journal of the European Economic Association between 1998 and 2018. The development of geographical concentration is examined using data on authors' affiliations at the time of the respective publication. Results show that research output produced by US-affiliated economists increased slower than overall research output, leading to a decrease in geographical concentration. Several proxies for scientific quality indicate that experiments conducted in Europe are of higher quality than experiments conducted in North America: European experiments rely on a larger total number of participants as well as participants per treatment, and receive more citations compared to experiments conducted in North America. Examining laboratory experiments published in the AER more closely, we find that papers authored by economists with US-affiliations receive significantly fewer citations in the first 5 and 10 years after publication compared to papers by authors from the rest of the world.
\end{abstract}

JEL classification: A11, A14, C90, I23

Keywords: laboratory experiments, favoritism, geographical concentration, methodological standards, network effects

\footnotetext{
$\square$ Janis Cloos is PhD student at the chair of Behavioral Management and Economics at the Clausthal University of Technology, janis.cloos@tu-clausthal.de. Matthias Greiff is professor for Behavioral Management and Economics at the Clausthal University of Technology, matthias.greiff@tu-clausthal.de. Hannes Rusch is assistant professor at the Microeconomics and Public Economics Department at Maastricht University, h.rusch@maastrichtuniversity.nl. We thank Max Albert, Jeanette Brosig-Koch, Gary Charness, Björn Frank, Daniel Hamermesh, Sebastian Kruegel, Sarah Necker, the participants of the 2019 Economic Science Association (ESA) North American Meeting in Los Angeles, the participants of the $14^{\text {th }}$ Nordic Conference on Behavioral and Experimental Economics in Kiel, the participants of the 2017 Annual Meeting of the German Association for Experimental Economic Research (GfeW e.V.) in Kassel, and seminar participants at the University of Passau, HSU Hamburg and the University of Marburg for feedback and comments. Simone Koch provided excellent research assistance.
} 


\section{Introduction}

Several studies on publications in academic top journals show a dominant position of US research. It is an important question whether this dominance is the product of the sheer size of the US, of discrimination, or of other barriers to entry for researchers from the rest of the world. In the last decades, research on geographical and institutional concentration has received a lot of attention. For economic top journals, several studies show that a large but declining share of research is produced by US-based economists (Ek and Henrekson 2019, Glötzl and Aigner 2017, Kocher and Sutter 2001, Kalaitzidakis et al. 1999, Hodgson and Rothman 1999, Elliott et al. 1998, Frey and Pommerehne 1988).

In this paper, we focus on one particular field: experimental economics. Our analyses cover all laboratory experiments published between 1998 and 2018 in three important journals: the American Economic Review (AER), arguably one of the top journals for general economics worldwide, Experimental Economics (EE), the top field journal, and the Journal of the European Economic Association (JEEA), arguably the European top journal for general economics.

Our first contribution is an analysis of geographical concentration. We examine its development using data on authors' affiliations at the time of publication. Similar to previous work, our analysis reveals that the US still has a dominant position, but also that US dominance has decreased over time.

Our second contribution is an analysis of several proxies for the scientific quality of the published experiments. Drawing on the literature on experimental methods, we identify four proxies that are indicative of the quality of laboratory experiments and can be determined by the experimenters: the total number of participants, the number of participants per treatment, the number of treatments, and the strength of monetary incentives (measured as real 2015-USD per average participant-minute). To ensure comparability between experiments, we restrict our analyses to laboratory experiments and exclude all other types of experiments.

Our results show substantial differences between Europe and North America, the two regions where more than $80 \%$ of the experiments were conducted. For all three journals, experiments conducted in Europe have a larger number of participants per treatment. In the AER and in EE, experiments conducted in Europe also have a larger total number of participants. We find no 
differences in the strength of incentives. Hence, the (inflation-adjusted) total costs of experiments are higher for experiments conducted in Europe.

Our third contribution is a test for whether the dominance of US-affiliated economists on the editorial board of the AER could give rise to editorial favoritism. Editorial favoritism can be a serious problem for scientific progress (Brogaard et al. 2014, Medoff 2003, Laband and Piette 1994a). It arises when editorial decisions are not exclusively based on scientific criteria but also on non-scientific criteria, such as authors' institutional connections: if non-scientific criteria influence editorial decisions, colleagues with social ties to the members of a small elite of editors will find it "easier" to get their papers accepted. Such favoritism is a problem when the quality of published research suffers from it, i.e. when the editors' buddies' papers are published while better papers by no-names are rejected.

Unlike the existing literature (Brogaard et al. 2014, Medoff 2003, Laband and Piette 1994a), our analysis of editorial favoritism clusters groups by geographical region (North America and Europe) and not by individual institution (e.g., university). As we have no data on submissions, we focus on published papers. With editorial favoritism present, we expect papers from authors without social ties to the editors to be of higher quality than papers from authors with social ties to the editors, at least on average.

The number of participants and treatments, and the strength of monetary incentives constitute a set of ex ante proxies for quality that are available for editors when deciding about publication. However, originality, timeliness, and practical relevance are also strongly related to a paper's quality, but are not captured by our proxies for quality. Therefore, we use the number of citations that a paper received in the 5 and 10 years after publication as an ex post proxy for quality. Assuming that editors exclusively aim to maximize their journal's impact factor (which is debatable, but see Card and DellaVigna forthcoming), there should be no systematic difference in the quality of papers authored by economists with and without affiliations on the editorial board's continent. However, this is not always the case. We find that AER papers (co-)authored by economists with a US affiliation receive, on average, fewer citations in the 5 and 10 years following publication compared to papers by European authors published in the same outlet. We do not find this pattern for papers published in EE and the JEEA. This suggests 
that the AER's selection criteria fail to maximize the journal's impact factor, or that editors pursue other goals ${ }^{1}$.

To the best of our knowledge, this is the first study in which the quality of laboratory experiments is compared across journals and geographical regions. By incorporating objectively measurable quality proxies into our analysis, we shed some light on the question of to what extent (differences in) citations are driven by (differences in) quality characteristics and social ties. In this respect, our analysis goes beyond the existing work on editorial favoritism. Surprisingly and despite the large differences in the total number of participants and participants per treatment, we find no robust evidence for any effect of these quality proxies on the number of citations. Yet, we are confident that our results provide insights for editors on how to improve their journals' selection criteria and increase their journals' impact factors.

The remainder of this paper is organized as follows. We start by reviewing the related literature in section 2. In section 3, we describe our data set and our selection criteria for journals and papers before we examine geographical concentration in section 4 . In section 5 , we compare the laboratory experiments conducted in Europe and North America using our proxies for quality. We describe our tests for editorial favoritism in section 6 and conclude in section 7 .

\section{Related Literature}

\subsection{Geographical Concentration}

Kalaitzidakis et al. (1999) look at ten high-quality journals from 1991 to 1996 and show that between $69 \%$ and $90 \%$ of all authors have an affiliation in North America. Based on all papers in the top 15 journals between 1977 and 1997, Kocher und Sutter (2001) find that $72.2 \%$ of these papers were authored by economists working in the US. They also find that US dominance reduced over time. Ek and Henrekson (2019) look at the top-five economics journals and show that between $82 \%$ (in 1994) and 65\% (in 2017) of all authors have an affiliation in North America, and 95\% of the North American authors have their affiliation in the US. Other studies

\footnotetext{
${ }^{1} \mathrm{We}$ decided to focus on editors and not on referees for three reasons. First, editors have the power to overrule referees' suggestions. Second, editors tend to select referees to whom they have easy access, implying that social ties between author and editor and between author and referee are correlated (Hamermesh 1994). And third, data on referees is hard to obtain.
} 
find similar results regarding the decline in US dominance (Glötzl and Aigner 2017, Neary et al. 2003) $)^{2}$. For the field of laboratory experiments, we expect a similar pattern.

\subsection{Social Ties and Editorial Favoritism}

Editorial favoritism occurs when it is easier for an economist with a social tie to one or more editors to get her paper accepted, compared to a paper of the same quality submitted by an economist without such a social tie. Editorial favoritism might occur if, for example, editors favor their former PhD students, or authors employed at the same university or the same region ${ }^{3}$.

A relatively high share of papers by authors who are connected to one of the journal's editors is often taken as an indication for editorial favoritism. However, this is neither necessary nor sufficient. As pointed out by Brogaard et al. $(2014,252)$, the decisive question is “... whether editors use information advantages to improve selection decisions, or whether they bow to conflicts of interest."

The earliest study on editorial favoritism in economics is Laband and Piette (1994a), who analyze all papers published in 28 journals in the year 1984. Laband and Piette define a social tie as one of the authors and one member of the editorial board having received their $\mathrm{PhD}$ from the same university or one of the authors and one member of the editorial board being affiliated with the same university in 1984. Controlling for papers' length, journal quality, author's age, gender, and reputation, they find a positive correlation between the number of citations in the 5 years after publication and the existence of a social tie. They note that some well-cited highquality papers mainly drive this positive correlation. However, their results also show that economists who had social ties to the editors authored more than two thirds of the papers with remarkably few citations. Thus, Laband and Piette find no clear evidence for or against editorial favoritism. Based on their results, they conclude that "on balance, journal editors use their professional connections to search out good papers, rather than print substandard material

\footnotetext{
${ }^{2}$ US dominance can be observed not only among authors but also among editors. Hodgson and Rothman (1999, 168 - 170) look at 30 high quality journals and show that more than $83 \%$ of all editorial board members come from the US. In section 6.1 we describe the composition of the editorial boards for the journals we examined.

${ }^{3}$ Discrimination implies that papers with a lower quality are accepted for publication, while papers with a higher quality are rejected. If the paper's true quality is somehow revealed after publication (possibly, by the number of citations), this might damage a journal's reputation (a loss in the journal's impact factor). So how can discrimination persist? It can persist as long as the true quality is not revealed, or if there is a form of collusion between editors of different journals, who all discriminate in the same way. In experimental oligopoly markets it has been found that a shrinking market facilitates collusion (Abbink and Brandts 2009). In economics we have a similar situation. As more and more journals are published in English but outside the US (e.g., the JEEA), the US-market is shrinking. However, rather than investigating discrimination over time, we focus on the possible existence of discrimination in one particular field.
} 
written by their colleagues or buddies" (Laband and Piette 1994a, 200). Medoff (2003) analyzes all papers published in six core journals in 1990 and also finds that papers by authors with a social tie to the editors or co-editors receive a higher number of citations in the years following publication. He examines the citations received in the 5 and 10 years after publication and observes that the positive effect of social ties is stable over time.

More recently, several papers have examined further effects of social ties. Based on an analysis of 50,000 articles in 30 major economics and finance journals since 1955, Brogaard et al. (2014) show that the publication rates of authors in these journals increase by $100 \%$ as soon as one of their current colleagues is the editor in charge of the corresponding journal. Their results show that articles by authors with social ties to editors receive significantly more citations than articles by authors without such connections. Colussi (2018) analyzes all 1,620 papers published in four top-journals (AER, Econometrica, Journal of Political Economy (JPE), Quarterly Journal of Economics (QJE)) between 2000 and 2006. Colussi's results show that editors are more likely to accept papers from colleagues (an $8 \%$ increase at the baseline) and former PhD students (a 14\% increase at the baseline). Further, he shows that about $43 \%$ of all papers were written by an author connected to at least one editor in charge of the journal at the time of publication. However, since the base-rate of submitting authors is unknown, this value is difficult to interpret. Heckman (2017) finds a similar pattern in two house journals, the University of Chicago's JPE and Harvard's QJE. Using data on publications from 2000 to 2016, he shows that $14.3 \%$ of all papers in the JPE come from authors affiliated with the University of Chicago, and that $24.7 \%$ of all publications in the QJE come from authors affiliated with Harvard.

Taken together, thus, previous studies suggest that (1) social ties can improve the chances of getting published because they reduce editors' search costs for high-quality papers, and (2) that conditional on being accepted for publication, on balance, papers from authors with social ties receive more citations. None of the studies finds clear evidence for editorial favoritism (but see Shepherd, 1995, for anecdotal evidence).

The studies discussed above focus on editorial favoritism and the effects of social ties. They discuss social ties exclusively at the institutional level but not at the regional level. As Frey and Pommerehne $(1988,106-107)$ point out, it may also be generally possible that it is easier for American economists to publish in American-dominated journals than it is for non-American economists. 
Existing studies on editorial favoritism (Laband and Piette 1994a, Medoff 2003) use data on individual authors (e.g., affiliations, age, gender, reputation) and characteristics of the papers (e.g., length, JEL code, position within the journal issue). These characteristics, however, are not related to any methodological standards. In section 5.1, we argue that there are four proxies that capture different methodological standards for laboratory experiments. Our analysis of editorial favoritism for laboratory experiments includes these four proxies, and thus extends the existing literature on editorial favoritism.

\section{Data on Laboratory Experiments}

\subsection{Selection Criteria}

Although we are interested in the overall development of experimental economics, we decided to focus exclusively on papers that report results from laboratory experiments. Precisely, we focus on laboratory experiments that generate data in a controlled process using student participants who interact in an artificial environment ${ }^{4}$. In order to ensure the greatest possible comparability, we do not consider papers that contain other types of experiments ${ }^{5}$.

For laboratory experiments, objectively measurable proxies for an experiment's quality exist. This is because, compared to field experiments, laboratory experiments have the exclusive advantage that the experimenter has a high degree of control. Proxies for an experiment's quality are the total number of participants, the number of treatments, the number of participants per treatment, and the strength of incentives. We describe these proxies in more detail in section 5.1.

There is no doubt that field experiments play an important role in experimental economics (for a detailed discussion see, Czibor et al. 2019, Carpenter et al. 2005, Harrison and List 2004). However, in field experiments at least one of our quality proxies cannot be controlled. For example, an artefactual field (or lab-in-the-field) experiment relies on a population of participants specifically selected for a given research question (e.g., chess players in Levitt et al. 2011) that cannot be fully controlled by the experimenter. Similarly, framed field experiments take place in a natural environment (e.g., the National Rural Support Programme Offices in Afzal et al. 2017) which also cannot be fully controlled by the experimenter. In

\footnotetext{
${ }^{4}$ Our data contain papers where the majority of the participants were students. Papers where the majority of participants belonged to special groups (such as job professionals or caste members) are not included in the data set.

${ }^{5}$ For example, the AER paper by Imas (2016) is not included in our data set because the paper contains two laboratory experiments and a robustness check conducted online via Amazon M-Turk.
} 
natural field experiments, moreover, both the participant population and the environment cannot be controlled exogenously.

\subsection{Our Data Set}

Our data set contains 583 papers published between 1998 and 2018 (410 from EE, 135 from the AER (including papers from AER's Papers and Proceedings) and 38 from the JEEA) ${ }^{6}$. We chose 1998 as the starting year for our analysis because EE was founded that year. EE is the specialized field journal of the Economic Science Association. It publishes laboratory and field experiments as well as related theoretical papers and reviews. We chose the AER and the JEEA because they are the official journals of the American Economic Association and the European Economic Association, respectively. Both are general interest journals and publish only a small share of laboratory experiments ${ }^{7}$. We have decided to collect data from these relatively high ranked journals to ensure that the individual papers have received a certain number of citations and because we assume that the journals receive a high number of submissions from different geographical regions.

For each paper in our data set, we collected data on:

- the authors and their affiliations at the time of publication,

- the number of citations received by the individual authors in the 5 years before publication,

- the total number of pages,

- the total number of references,

- the journal's impact factors in the year the paper was published, and

- the paper's number of citations in the 5 and 10 years after publication.

In addition, we extracted data on the characteristics of the laboratory experiments reported in the papers. If available, for each laboratory experiment we collected data on:

- the total number of participants,

- the number of treatments,

- the duration of the experiment,

\footnotetext{
${ }^{6} \mathrm{~A}$ full list of the included papers can be found in the supplementary material.

${ }^{7}$ On the IDEAS/RePEc Simple Impact Factors for Journals list the AER is ranked $10^{\text {th }}$, the JEEA is ranked $19^{\text {th }}$ and $\mathrm{EE}$ is ranked $35^{\text {th }}$ (see https://ideas.repec.org/top/top.journals.simple.html, accessed August 29 2019). On the latest version of the Journal Quality List of Anne-Wil Harzing, which provides an overview of several different ratings, the AER is rated A+ and the JEEA and EE are both rated A (see https://harzing.com/download/jql_title_2019-02.pdf, accessed August 29 2019).
} 
- average earnings per participant, and

- the year in which the experiment was conducted.

Citation data was obtained from Web of Science. Data on impact factors were taken from CitEc, a RePEc service that provides citation data for economics ${ }^{8}$. All other data were obtained directly from the published papers. As not all papers report data on all characteristics, our data set contains some papers for which some or all of the experiment's characteristics are missing. In case of missing values, we tried to obtain the data from working paper versions or directly from the authors, which was successful in some cases.

\section{Geographical Concentration in Experimental Economics}

In this section, we examine the geographical concentration of published laboratory experiments at the country-level. In section 4.1, we look at the country shares for each journal for the longest available period. In section 4.2, we examine how geographical concentration has changed over time.

We measure geographical concentration as follows (see also Combes and Linnemer 2003, Kocher und Sutter 2001). Let $I F_{i}$ be the 2-year impact factor of the journal in which paper $i$ was published in the year the paper was published. Let $n_{i}$ be the number of authors of paper $i$. An author's weight is then given by $I F_{i} / n_{i}$. The weighted score for a single country and a given time period is calculated by aggregating the values of all authors whose affiliated institution was located in this country (at the time of publication). Given the weighted scores of all countries, we compute each country's share.

\subsection{Pooled Over Time}

Table 1 shows the shares for selected countries ${ }^{9}$. The first three columns depict the results by journal, the last column presents the aggregate results for laboratory experiments published in all three journals. Appendix Table 14 lists all countries' scores and shares by journal. Our results are qualitatively similar if we do not weight individual papers by the journal's impact factor, so that each author's weight is given by $1 / n_{i}$.

\footnotetext{
${ }^{8}$ For the AER see, http://citec.repec.org/s/2018/aeaaecrev.html, for EE see, http://citec.repec.org/s/2018/kapexpeco.html and for the JEEA see, http://citec.repec.org/s/2018/blajeurec.html (accessed July 9, 2019). Data for Experimental Economics' impact factor for 1998 and for the JEEA's impact factor before 2011 was not available.

${ }^{9}$ We have assigned Israel, Russia and Turkey to Europe and Guatemala and Mexico to North America throughout the whole paper.
} 


\begin{tabular}{|l|c|c|c|c|}
\hline \multirow{2}{*}{} & \multicolumn{4}{|c|}{ Shares } \\
\cline { 2 - 5 } & AER & EE & JEEA & all three \\
\hline Austria & 2.81 & 4.86 & 0.00 & 3.73 \\
\hline France & 0.69 & 3.03 & 3.28 & 2.28 \\
\hline Germany & 4.35 & 12.08 & 11.62 & 9.47 \\
\hline Israel & 1.59 & 0.84 & 0.00 & 1.01 \\
\hline Italy & 0.42 & 3.50 & 1.73 & 2.31 \\
\hline Netherlands & 3.15 & 4.68 & 8.21 & 4.50 \\
\hline Norway & 0.58 & 0.68 & 7.05 & 1.24 \\
\hline Spain & 2.87 & 5.88 & 2.28 & 4.55 \\
\hline Sweden & 0.76 & 1.25 & 0.00 & 0.97 \\
\hline Switzerland & 5.36 & 2.24 & 17.86 & 4.73 \\
\hline UK & 5.79 & 8.80 & 10.61 & 7.97 \\
\hline Other European countries & 0.83 & 1.89 & 0.00 & 1.36 \\
\hline Europe & $\mathbf{2 9 . 2 0}$ & $\mathbf{4 9 . 7 3}$ & $\mathbf{6 2 . 6 4}$ & $\mathbf{4 4 . 1 1}$ \\
\hline US & 62.51 & 37.84 & 29.10 & 45.22 \\
\hline Other North American countries & 1.62 & 3.06 & 1.71 & 2.46 \\
\hline North America & $\mathbf{6 4 . 1 3}$ & $\mathbf{4 0 . 9 0}$ & $\mathbf{3 0 . 8 1}$ & $\mathbf{4 7 . 6 8}$ \\
\hline Australia and NZ & 2.58 & 4.99 & 2.32 & 3.94 \\
\hline Asia & 3.56 & 4.09 & 2.96 & 3.81 \\
\hline South America & 0.54 & 0.29 & 1.28 & 0.46 \\
\hline Other continents & $\mathbf{6 . 6 7}$ & $\mathbf{9 . 3 7}$ & $\mathbf{6 . 5 5}$ & $\mathbf{8 . 2 1}$ \\
\hline Total & $\mathbf{1 0 0 . 0 0}$ & $\mathbf{1 0 0 . 0 0}$ & $\mathbf{1 0 0 . 0 0}$ & $\mathbf{1 0 0 . 0 0}$ \\
\hline
\end{tabular}

Table 1: Geographical concentration, countries' relative shares for selected countries, pooled data from 1998 to 2018 for the AER, from 1999 to 2018 for EE and from 2011 to 2018 for the JEEA. Continents are marked in bold.

We see that US economists are dominant in all journals. For the AER this dominance is most pronounced. When looking at the European countries, Germany, the UK, Switzerland, Spain, the Netherlands, and Austria stick out because they have the highest outputs within Europe.

\subsection{Development Over Time}

Looking at development over time, we divide the 20-year period from 1999 to 2018 into four five-year periods ${ }^{10}$. Table 2 shows the scores and shares of all countries with a share larger than $1 \%$ (for the whole period from 1999 to 2018). Scores and shares of all countries can be found in appendix Table 15. The analyses in Table 2 and Table 15 only contain data on papers from the AER and EE, as CitEc impact factors for the JEEA are available only for 2011-2018.

The first result that sticks out is the sharp increase in the field's research output. Looking at the total output by aggregating scores over all countries (Table 2 and appendix Table 15), we see an increase from 105.85 (1999-2003) to 279.14 (2004-2008) to 584.54 (2009-2013) followed by a decrease to 416.92 (2014-2018). The decrease in the most recent period could be due to

\footnotetext{
${ }^{10}$ We exclude observations from 1998, as CitEc impact factors for EE are only available from 1999 onward.
} 
four reasons: First, field and online experiments have developed into an increasingly established research method in recent years (see e.g., Stewart et al. 2015), partially replacing lab experiments. Second, a larger fraction of papers use multiple methods for data collection. These papers are not included in our data set. Third, other journals have become more open toward laboratory experiments or new journals that publish laboratory experiments have been established. And fourth, editors' tastes may have changed so that other research methods are preferred to laboratory experiments.

Based on the scores (appendix Table 15), we computed compound growth rates. Aggregated over all countries, the field's research output increased by $57.93 \%$ from each five-year period to the next. As expected, the compound growth rate for US-economists is much smaller (30.64\%). High growth rates are observed for Australia (211\%), Austria (192\%), Italy (157\%), China (133\%), Germany (118\%), the UK (114\%), the Netherlands (110\%) and Japan (100\%). Of course, these growth rates are partly due to the fact that some countries started from very low levels of research output in the period 1999-2003. 


\begin{tabular}{|c|c|c|c|c|c|}
\hline & \multicolumn{5}{|c|}{ Shares } \\
\hline & \multicolumn{5}{|c|}{ Scores } \\
\hline & $1999-2003$ & 2004-2008 & 2009-2013 & 2014-2018 & 1999-2018 \\
\hline \multirow[t]{2}{*}{ Austria } & 0.63 & 0.12 & 6.79 & 3.99 & 4.09 \\
\hline & 0.67 & 0.34 & 39.71 & 16.63 & 57.34 \\
\hline \multirow[t]{2}{*}{ France } & 3.01 & 0.20 & 2.61 & 2.72 & 2.16 \\
\hline & 3.18 & 0.55 & 15.27 & 11.33 & 30.33 \\
\hline \multirow[t]{2}{*}{ Germany } & 4.78 & 5.53 & 9.56 & 12.63 & 9.22 \\
\hline & 5.06 & 15.43 & 55.91 & 52.66 & 129.38 \\
\hline \multirow[t]{2}{*}{ Israel } & 1.07 & 0.78 & 1.79 & 0.44 & 1.18 \\
\hline & 1.13 & 2.18 & 10.44 & 1.82 & 16.58 \\
\hline \multirow[t]{2}{*}{ Italy } & 0.61 & 1.23 & 3.06 & 2.66 & 2.40 \\
\hline & 0.65 & 3.44 & 17.91 & 11.09 & 33.60 \\
\hline \multirow[t]{2}{*}{ Netherlands } & 2.32 & 4.20 & 3.49 & 5.49 & 4.10 \\
\hline & 2.46 & 11.73 & 20.40 & 22.88 & 57.48 \\
\hline \multirow[t]{2}{*}{ Spain } & 1.70 & 2.81 & 8.46 & 1.82 & 4.78 \\
\hline & 1.80 & 7.85 & 49.46 & 7.59 & 67.02 \\
\hline \multirow[t]{2}{*}{ Sweden } & 1.01 & 1.70 & 0.23 & 1.86 & 1.07 \\
\hline & 1.07 & 4.74 & 1.37 & 7.76 & 14.95 \\
\hline \multirow[t]{2}{*}{ Switzerland } & 9.19 & 1.30 & 4.49 & 1.83 & 3.37 \\
\hline & 9.72 & 3.64 & 26.24 & 7.64 & 47.24 \\
\hline \multirow[t]{2}{*}{ UK } & 3.07 & 6.53 & 9.23 & 7.69 & 7.77 \\
\hline & 3.25 & 18.24 & 53.93 & 32.08 & 109.00 \\
\hline \multirow[t]{2}{*}{ Other Euro. countries } & 1.79 & 1.79 & 1.19 & 3.84 & 2.13 \\
\hline & 1.89 & 5.01 & 6.95 & 16.01 & 29.86 \\
\hline \multirow[t]{2}{*}{ Europe } & 29.18 & 26.21 & 50.91 & 44.97 & 42.26 \\
\hline & 30.89 & 73.16 & 297.59 & 187.49 & 592.79 \\
\hline \multirow[t]{2}{*}{ US } & 65.07 & 68.47 & 39.68 & 36.83 & 46.85 \\
\hline & 68.87 & 191.12 & 231.94 & 153.56 & 657.18 \\
\hline \multirow[t]{2}{*}{ Other NA countries } & 1.58 & 0.88 & 2.92 & 3.39 & 2.54 \\
\hline & 1.68 & 2.46 & 17.08 & 14.14 & 35.69 \\
\hline \multirow[t]{2}{*}{ North America } & 66.65 & 69.35 & 42.60 & 40.22 & 49.40 \\
\hline & 70.55 & 193.58 & 249.02 & 167.70 & 692.87 \\
\hline \multirow[t]{2}{*}{ Australia and NZ } & 2.34 & 1.57 & 4.59 & 5.67 & 4.09 \\
\hline & 2.48 & 4.39 & 26.84 & 23.63 & 57.33 \\
\hline \multirow[t]{2}{*}{ Asia } & 1.83 & 2.87 & 1.79 & 8.03 & 3.87 \\
\hline & 1.94 & 8.01 & 10.45 & 33.47 & 54.33 \\
\hline \multirow[t]{2}{*}{ South America } & 0.00 & 0.00 & 0.11 & 1.11 & 0.38 \\
\hline & 0.00 & 0.00 & 0.64 & 4.63 & 5.27 \\
\hline \multirow[t]{2}{*}{ Other continents } & 4.17 & 4.44 & 6.49 & 14.81 & 8.34 \\
\hline & 4.42 & 12.40 & 37.93 & 61.73 & 116.93 \\
\hline \multirow[t]{2}{*}{ Total } & 100.00 & 100.00 & 100.00 & 100.00 & 100.00 \\
\hline & 105.85 & 279.14 & 584.54 & 416.92 & 1402.61 \\
\hline
\end{tabular}

Table 2: Shares and scores for the geographical concentration of AER and EE authors for selected countries.

Data pooled over different periods. For each country, the first row reports the country's share and the second row reports the country's score. 
Looking at countries' relative shares (the upper row of each country in Table 2), we find that the US-dominance decreased from about $65.07 \%$ (1999-2003) to $36.83 \%$ (2014-2018) while several countries increased their relative shares. The countries that gained most are Germany (7.85\%), the UK (4.62\%), Australia (4.43\%), and the Netherlands (3.16\%). All this shows that geographical concentration has decreased. Indeed, this is confirmed if we look at the Herfindahl index ${ }^{11}$, which first increased from 0.332 (1999-2003) to 0.480 (2004-2008) but then decreased to 0.169 (2009-2013) and to 0.171 (2014-2018). In sum, our data show that for laboratory experimental economics, the geographical concentration of AER and EE authors has substantially decreased.

The discussion above focused on the development of impact-weighted research output. Note that we looked at output (i.e., published papers) without considering inputs (e.g., manpower, financial resources). Hence, we cannot say anything about a country's productivity. Because input data comparable across countries is not available, we follow Kocher and Sutter (2001) in using a country's population as proxy and compute each country's output per million inhabitants in appendix Table 16 and Table $17^{12}$.

Considering the first time period (1999-2003, see Table 16), we see that output per million inhabitants was below 0.2, except for Switzerland (1.36), New Zealand (0.46) and the US (0.25). Considering only the last period (2014-2018, see Table 17), we see that output was above 0.40 for several countries (Australia 0.90, Germany 0.65, Spain 0.60, UK 0.50, US 0.48) and we see some very high productivities in small countries (Austria 1.95, Singapore 1.40, the Netherlands 1.36, Norway 1.17, Switzerland 0.93, Denmark 0.83, Sweden 0.80, New Zealand $0.53)$.

Interestingly, there are some differences between our results and the results reported in Kocher and Sutter $(2001,414)$. They show that Israel has the highest and the US have the secondhighest productivity. UK ranks third, Switzerland ranks 9th, Germany ranks 17th and Spain ranks 19th. Recall that while Kocher and Sutter consider papers from all areas, we focus on

\footnotetext{
${ }^{11}$ The Herfindahl index is the sum of all countries' squared market shares. For a monopoly, the index is equal to one. Smaller numbers indicate less concentration.

12 This approach only gives a crude picture and has several shortcomings (c.f. Kocher and Sutter 2001, 414). It implicitly assumes that resources devoted to experimental economics is highly correlated with a country's inhabitants, which is problematic especially in large less-developed countries. Data for population sizes was taken from the World Bank (see, https://databank.worldbank.org/data/indicator/SP.POP.TOTL/1ff4a498/PopularIndicators, accessed May 22, 2019) and for Taiwan from the UN (see, https://population.un.org/wpp/Download/Standard/Population/, accessed May 22, 2019). To compute scores per million inhabitants for a specific time period we used the population size for the period's first year (e.g., 1999 population for the period 1999-2003).
} 
laboratory experimental economics. In addition, Kocher and Sutter consider data until 1997 while our data on geographical concentration start in 1999. Because of the different time periods and our specialization on one particular field, the results are not directly comparable, but a tentative explanation for the differences is that several European countries (Switzerland, Austria, Germany, Spain, the Netherlands) have specialized in experimental economics.

\section{Quality Characteristics}

In the preceding section, we described the development of geographical concentration by looking at the number of publications weighted by the journals' impact factor. Such an analysis neglects any differences between individual papers published within the same journal in a given year. If there are significant quality differences between different papers published in the same journal in a given year, the results from the preceding section could be biased. By focusing on the characteristics of individual experiments and papers, we try to uncover such differences in order to get a more detailed picture.

In subsection 5.1, we describe four proxies for the quality of laboratory experiments. We compare these proxies in subsection 5.2. This comparison reveals that there are differences regarding methodological standards between experiments conducted in North America and Europe. In subsection 5.3, we describe three proxies for the quality of papers that report experimental results. All seven proxies are available prior to publication and might inform editors' decisions. This is not the case for the number of citations a paper receives after publication, which we argue to be the most important ex post quality proxy in subsection 5.4. Finally, we compare the number of citations between experiments conducted in North America and Europe in subsection 5.5.

\subsection{Proxies for the Quality of Laboratory Experiments}

Our proxies for the quality of an experiment (shorthand: P1-P4) are objectively measurable. However, they are only proxies. Thus, it is possible that they only weakly correlate with the true quality of an experiment, which is of course unknown.

(P1 and P2) The first two quality proxies are the total number of participants, and the number of participants per treatment. Both are related to the experiment's statistical power. For a more detailed discussion of power analysis in experimental economics see Czibor et al. (2019), Ioannidis et al. (2017), Bellemare et al. (2016, 2014) and Zhang and Ortmann (2013). 
Experiments with higher power tend to generate fewer false positives and, hence, their results are more likely to replicate. This in turn could increase confidence in the experiment's results ${ }^{13}$.

For a given number of treatments, a larger total number of participants results in more observations, which increases statistical power if statistical testing is carried out at the participant-level. A similar proxy for quality is the number of participants per treatment. If an experiment contains a large number of treatments, and if the statistical analysis involves a pairwise comparison of treatments, the number of participants per treatment is a better proxy for the experiment's power.

Arguably, another possibility would be using the number of independent observations as a proxy for quality. Since the question of what constitutes an independent observation has no clear answer, we did not follow this route (see chapter 3 in Svorenčík and Maas 2016). Another, but related, aspect concerns the possibility to econometrically control for dependencies (see Moffatt 2015, 5-6). If dependencies are controlled for, the number of independent observations will underestimate the quality of the experiment ${ }^{14}$.

(P3) The third proxy is the number of treatments. Ceteris paribus, a larger number of treatments increases quality because it allows to test for more alternative explanations. By testing for a higher number of alternative explanations, authors increase the scientific value of their papers by linking the interpretation of their results to a larger number of existing papers and corroborating their claims better by ruling out more alternative hypotheses.

(P4) The fourth proxy is the strength of monetary incentives. According to the methodological literature on laboratory experiments, monetary incentives are related to the quality of an experiment. In fact, the use of monetary incentives is an established methodological standard in economics (see Hertwig and Ortmann 2001, 390) and all experiments in our data set use monetary incentives. Possibly, this is the case because experimental economists expect that they cannot publish their paper if they would use hypothetical rather than monetary incentives

\footnotetext{
${ }^{13}$ Camerer at al. (2016) were able to successfully replicate the results of 11 out of 18 experiments. With the goal of making replication studies more attractive, Drazen et al. (2019) suggest journal-based replication, in which the journal contracts a replication after a paper has been accepted but before it is published.

${ }^{14}$ For example, consider a $T$-times repeated public good game with stranger matching. Assume the experiment consists of two treatments, $S$ sessions per treatment, and $N$ participants per treatment. Due to the stranger matching protocol, all observations within the same sessions are dependent. The most conservative way would be to take a session's average contribution (pooled across participants and time) as one independent observation and compare session averages across treatments. Proceeding this way, we would have $S$ independent observations per treatment. If we would exploit the panel structure of the data and use a random effects model, we could use each single decision as an observation resulting in a total of $2 S T N$ observations.
} 
(Camerer and Hogarth 1999, 31) ${ }^{15}$. We operationalized the strength of monetary incentives by dividing a participant's average earnings (including the show-up fee) by the duration of the experiment (in minutes) and converting the result into real 2015 US-Dollars ${ }^{16}$.

Regarding the strength of monetary incentives, Davis and Holt (1993, 24-25) argue that incentives should be high enough to cover opportunity costs. This rule defines a lower limit for incentives but remains silent about the relation between the strength of incentives and behavior. Camerer and Hogarth $(1999,31)$ show that the strength of monetary incentives affects behavior and increases data quality. With stronger incentives, subjects are less likely to show thoughtless behavior or make errors, leading to lower variance and less noise in the data. This, in turn, leads to an increase in power, allows for more precise statistical testing, and increases the likelihood of successful replication. According to this line of reasoning, experimental economists could increase the quality of their experiments by paying higher rewards ${ }^{17}$.

Table 3 gives an overview of mean values for the quality proxies for the three journals. At first glance, we see that total number of participants, number of participants per treatment and number of treatments are higher for the AER and the JEEA than for EE. As Table 3 illustrates, the variable strength of monetary incentives could only be computed for $53 \%$ of AER papers, $72 \%$ of EE papers and $63 \%$ of JEEA papers. This is because, even in these prestigious journals, many papers do not report the number of participants, average earnings per participant, or the duration of the experiment.

\footnotetext{
${ }^{15}$ For a more detailed discussion of monetary incentives see Bardsley et al. (chapter 6, 2010), Ortmann (2009), Read (2005), Guala (chapter 11, 2005) and Rydval and Ortmann (2004).

${ }^{16}$ Data for exchange rates comes from fxtop.com. Data for CPI comes from https://data.oecd.org. In some papers it was not stated, in which year the experiment was conducted. In these cases we estimated the corresponding value by subtracting three years from the year of publication.

17 A related aspect that is discussed by Camerer and Hogarth (1999) concerns participants' cognitive abilities. Together with monetary incentives and intrinsic motivation, cognitive abilities affect participants' mental effort. However, the effect from incentives on mental effort is likely to be non-monotonic, as recognized by Davis and Holt: "No amount of money can motivate participants to perform a calculation beyond their intellectual capacities, any more than generous bonuses would transform most of us into professional athletes" (Davis and Holt 1993, 24). Because no data on participants' cognitive abilities are available, we could not include cognitive abilities in our set of quality proxies. We believe that this is unproblematic because there is no reason to expect any systematic differences in participants' cognitive abilities across experiments.
} 


\begin{tabular}{|l|c|c|c|}
\hline & AER & EE & JEEA \\
& $N=135$ & $N=410$ & $N=38$ \\
\hline P1: total \# of participants & 255.93 & 194.49 & 289.65 \\
& $(203.37)$ & $(128.45)$ & $(183.78)$ \\
& $N=128$ & $N=407$ & $N=37$ \\
\hline P2: \# participants per treatment & 69.39 & 55.33 & 61.50 \\
& $(90.00)$ & $(40.97)$ & $(43.44)$ \\
& $N=126$ & $N=405$ & $N=31$ \\
\hline P3: \# treatments & 4.40 & 3.90 & 4.84 \\
& $(3.01)$ & $(2.29)$ & $(2.50)$ \\
P4: strength of monetary incentives & $N=133$ & $N=407$ & $N=32$ \\
& 0.40 & 0.31 & 0.32 \\
& $(0.24)$ & $(0.14)$ & $(0.16)$ \\
& $N=72$ & $N=294$ & $N=24$ \\
\hline
\end{tabular}

Table 3: Mean values, standard deviations (in parentheses) and number of observations for experiments' proxies.

\subsection{Are there Differences in Methodological Standards?}

In this subsection, we examine whether there are clearly defined methodological standards with regard to the ex ante proxies for quality described above. If this were the case, one would expect to find no differences regarding these proxies between experiments conducted in different regions.

In the following, we look only at laboratory experiments conducted in North America or Europe. More than $82 \%$ of the papers in our dataset contain laboratory experiments conducted in these two regions.

\begin{tabular}{|l|c|c|c|c|}
\hline $\begin{array}{l}\text { P1: total \# } \\
\text { participants }\end{array}$ & North America & Europe & both regions & $p$-value \\
\hline AER & 220.16 & 368.49 & 271.93 & 0.0004 \\
& $(170.85)$ & $(257.87)$ & $(216.22)$ & \\
& $N=69$ & $N=37$ & $N=106$ & \\
\hline EE & 167.03 & 204.93 & 186.27 & 0.0078 \\
& $(94.83)$ & $(126.44)$ & $(113.42)$ & \\
& $N=164$ & $N=169$ & $N=333$ & \\
\hline JEEA & 246.92 & 301.81 & 280.82 & 0.9294 \\
& $(121.16)$ & $(221.31)$ & $(189.09)$ & \\
& $N=13$ & $N=21$ & $N=34$ & \\
\hline all three & 186.15 & 240.56 & 212.26 & 0.0003 \\
& $(124.78)$ & $(175.46)$ & $(153.51)$ & \\
& $N=246$ & $N=227$ & $N=473$ & \\
\hline
\end{tabular}

Table 4: Mean values, standard deviations (in parentheses) and number of observations for total number of participants by region and journal. Last column is the p-value from a two-sided Mann-Whitney test. 


\begin{tabular}{|l|c|c|c|c|}
\hline $\begin{array}{l}\text { P2: \# } \\
\text { participants } \\
\text { per } \\
\text { treatment }\end{array}$ & North America & Europe & both regions & $p$-value \\
\hline AER & 54.78 & 111.26 & 74.68 & 0.0001 \\
& $(45.74)$ & $(146.45)$ & $(97.50)$ & \\
& $N=68$ & $N=37$ & $N=105$ & \\
\hline EE & 49.07 & 59.97 & 54.60 & 0.0031 \\
& $(33.96)$ & $(40.76)$ & $(37.91)$ & \\
& $N=163$ & $N=168$ & $N=331$ & 0.0276 \\
& 37.69 & 73.10 & 60.89 & \\
\hline JEEA & $(19.22)$ & $(49.63)$ & $(44.68)$ & \\
& $N=10$ & $N=19$ & $N=29$ & \\
\hline all three & 50.21 & 69.56 & 59.53 & $<0.0001$ \\
& $(37.28)$ & $(72.56)$ & $(57.82)$ & \\
\hline
\end{tabular}

Table 5: Mean values, standard deviations (in parentheses) and number of observations for participants per treatment by region and journal. Last column is the p-value from a two-sided Mann-Whitney test.

\begin{tabular}{|l|c|c|c|c|}
\hline $\begin{array}{l}\text { P3: \# } \\
\text { treatments }\end{array}$ & North America & Europe & both regions & $p$-value \\
\hline AER & 4.30 & 4.79 & 4.47 & 0.5527 \\
& $(2.96)$ & $(3.47)$ & $(3.13)$ & \\
& 3 & 4 & 3 & \\
& $N=73$ & $N=38$ & $N=111$ & \\
\hline EE & 3.92 & 3.79 & 3.85 & 0.4391 \\
& $(2.30)$ & $(2.34)$ & $(2.31)$ & \\
& 4 & 4 & 4 & \\
& $N=165$ & $N=168$ & $N=333$ & 0.9479 \\
\hline JEEA & 5.00 & 4.63 & 4.77 & \\
& $(3.16)$ & $(2.14)$ & $(2.51)$ & \\
& 2 & 3 & $3 \& 4$ & \\
& $N=11$ & $N=19$ & $N=30$ & \\
& 4.08 & 4.03 & 4.05 & 0.7020 \\
all three & $(2.55)$ & $(2.57)$ & $(2.56)$ & \\
& 4 & 4 & 4 & \\
& $N=249$ & $N=225$ & $N=474$ & \\
\hline
\end{tabular}

Table 6: Mean values, standard deviations (in parentheses), modes and number of observations for number of treatments by region and journal. Last column is the p-value from a two-sided Mann-Whitney test. 


\begin{tabular}{|l|c|c|c|c|}
\hline $\begin{array}{l}\text { P4: strength of } \\
\text { monetary incentives }\end{array}$ & North America & Europe & both regions & $p$-value \\
\hline AER & 0.37 & 0.45 & 0.41 & 0.2544 \\
& $(0.17)$ & $(0.32)$ & $(0.25)$ & \\
& $N=35$ & $N=29$ & $N=64$ & \\
\hline EE & 0.30 & 0.33 & 0.32 & 0.0791 \\
& $(0.12)$ & $(0.16)$ & $(0.14)$ & \\
& $N=116$ & $N=131$ & $N=247$ & \\
\hline JEEA & 0.33 & 0.32 & 0.32 & 0.8828 \\
& $(0.14)$ & $(0.17)$ & $(0.16)$ & \\
& $N=6$ & $N=16$ & $N=22$ & \\
\hline all three & 0.32 & 0.35 & 0.33 & 0.0693 \\
& $(0.14)$ & $(0.20)$ & $(0.17)$ & \\
& $N=157$ & $N=176$ & $N=333$ & \\
\hline
\end{tabular}

Table 7: Mean values, standard deviations (in parentheses) and number of observations for strength of monetary incentives by region and journal. Last column is the p-value from a two-sided Mann-Whitney test.

Table 4 to Table 7 show the mean values of the ex ante proxies for quality by journal and region. With respect to the total number of participants or the number of participants per treatment, there seems to be no universal methodological standard. Rather, there seem to be systematic differences between experiments conducted in both regions.

Except for the JEEA, experiments conducted in Europe involve a significantly larger total number of participants. For all journals, European experiments have a significantly larger number of participants per treatment. Possibly, these differences indicate differences with regard to what constitutes an independent observation, as emphasized by Frans van Winden:

"I can remember at the Amsterdam meetings that there were some heated discussions, and they were related to three topics. First of all, what is an independent observation? What I remember is that people from the United States were more liberal in the sense that they applied parametric statistics whereas the Germans, especially of course Reinhard Selten and the group he influenced, were stricter on that."

(Frans van Winden, cited in Svorenčík and Maas 2016, 188-198).

Another possible explanation for the differences in the total number of participants and the number of participants per treatment (P1 and $\mathrm{P} 2)$ is that there are differences in the types of experiments conducted in the two regions (e.g., individual decision making, public good games, market experiments...) that require different numbers of participants. If there are systematic differences in the distribution of types, our measures P1 and P2 will be biased. A cursory look into our data reveals that for almost all types the number of participants is higher for experiments conducted in Europe, indicating that it is unlikely that our results are driven by 
differences in types. However, while some experiments can be easily classified as certain types, there are many experiments that are hard to classify.

With regard to the number of treatments, there are no significant differences between NorthAmerican and European experiments. Across journals and continents, the mode of treatments per experiment is four.

Regarding the strength of monetary incentives there also are no significant differences. This observation is compatible with the existence of a common standard for how to incentivize participants in Europe and North America.

Our results for the total number of participants and the strength of monetary incentives could suggest that experimental economists from Europe have to pay a higher price for publishing their papers, compared to experimental economists from North America. Another explanation might be that economists in Europe have easier access to research funding compared to their colleagues in the $\mathrm{US}^{18}$.

The differences in the total number of participants could be driven by a cohort effect. Section 4.2 showed that the US's research output was very high in the first two periods before it decreased. If the total number of participants increases over time, and if this increase has the same magnitude for experiments conducted in North America and Europe, the differences in the total number of participants in Table 4 would only reflect the fact that the share of experiments conducted in the US decreased. To rule out such cohort effects, we look at the total number of participants for four periods. Table 8 shows that there are almost no significant differences in the total number of participants for the first and second period. However, from the periods 2009-2013 and 2014-2018, the total number of participants for European experiments for both journals is always higher and in most cases the difference is statistically significant. Moreover, the difference between North America and Europe increases over time. This suggests that the differences in the total number of participants for the pooled data (19992018) are not driven by the decreasing share of US output. Rather, it is driven by differences in the total number of participants in the two most recent periods.

\footnotetext{
${ }^{18}$ We thank Gary Charness for drawing our attention to this aspect. Unfortunately, there are no sources for the amount of research funding for experimental economists in different regions. However, we consider it unlikely that there is a causal relationship between the availability of research funding and the average total number of participants. Even if research funds were easier available in Europe, they could be used, for example, to carry out more single projects.
} 


\begin{tabular}{|c|c|c|c|c|c|}
\hline period & $\begin{array}{l}\text { P1: total number of } \\
\text { participants }\end{array}$ & $\begin{array}{l}\text { North } \\
\text { America }\end{array}$ & Europe & both regions & $p$-value \\
\hline \multirow{3}{*}{ 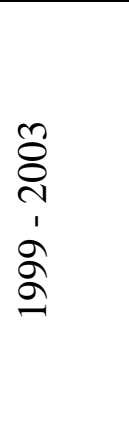 } & AER & $\begin{array}{c}240.65 \\
(163.21) \\
N=20\end{array}$ & $\begin{array}{c}230.00 \\
(124.78) \\
N=10\end{array}$ & $\begin{array}{c}237.10 \\
(149.37) \\
N=30\end{array}$ & 0.9140 \\
\hline & $\mathrm{EE}$ & $\begin{array}{c}134.15 \\
(75.65) \\
N=41\end{array}$ & $\begin{array}{c}154.85 \\
(99.97) \\
N=34\end{array}$ & $\begin{array}{c}143.53 \\
(87.51) \\
N=75\end{array}$ & 0.3522 \\
\hline & both & $\begin{array}{c}169.07 \\
(121.62) \\
N=61\end{array}$ & $\begin{array}{c}171.93 \\
(109.29) \\
N=44\end{array}$ & $\begin{array}{c}170.27 \\
(116.08) \\
N=105\end{array}$ & 0.6353 \\
\hline \multirow{3}{*}{ 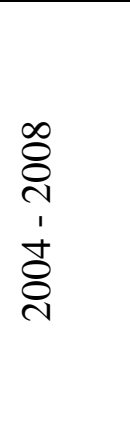 } & AER & $\begin{array}{c}205.54 \\
(183.73) \\
N=24\end{array}$ & $\begin{array}{c}432.71 \\
(294.28) \\
N=7\end{array}$ & $\begin{array}{c}256.84 \\
(229.18) \\
N=31\end{array}$ & 0.0170 \\
\hline & $\mathrm{EE}$ & $\begin{array}{c}138.66 \\
(72.10) \\
N=35\end{array}$ & $\begin{array}{c}130.52 \\
(104.34) \\
N=21\end{array}$ & $\begin{array}{c}135.61 \\
(84.79) \\
N=56\end{array}$ & 0.2332 \\
\hline & both & $\begin{array}{c}165.86 \\
(132.41) \\
N=59\end{array}$ & $\begin{array}{c}206.07 \\
(212.29) \\
N=28\end{array}$ & $\begin{array}{c}178.80 \\
(162.26) \\
N=87\end{array}$ & 0.8905 \\
\hline \multirow{3}{*}{$\begin{array}{l}\frac{m}{8} \\
\text { ㄱ } \\
\text { ' } \\
\stackrel{্}{8}\end{array}$} & AER & $\begin{array}{c}270.31 \\
(190.69) \\
N=16\end{array}$ & $\begin{array}{c}389.56 \\
(257.60) \\
N=16\end{array}$ & $\begin{array}{c}329.94 \\
(231.03) \\
N=32\end{array}$ & 0.1458 \\
\hline & $\mathrm{EE}$ & $\begin{array}{l}162.86 \\
(79.42) \\
N=28\end{array}$ & $\begin{array}{c}217.24 \\
(129.07) \\
N=49\end{array}$ & $\begin{array}{c}197.47 \\
(116.00) \\
N=77\end{array}$ & 0.0376 \\
\hline & both & $\begin{array}{c}201.93 \\
(139.21) \\
N=44\end{array}$ & $\begin{array}{c}259.66 \\
(183.42) \\
N=65\end{array}$ & $\begin{array}{c}236.36 \\
(168.71) \\
N=109\end{array}$ & 0.0229 \\
\hline \multirow{3}{*}{ 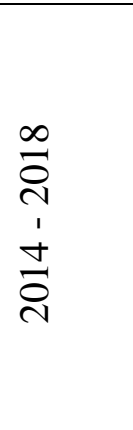 } & AER & $\begin{array}{c}124.44 \\
(51.06) \\
N=9\end{array}$ & $\begin{array}{c}518.00 \\
(374.84) \\
N=4\end{array}$ & $\begin{array}{c}245.54 \\
(269.46) \\
N=13\end{array}$ & 0.0699 \\
\hline & $\mathrm{EE}$ & $\begin{array}{c}208.00 \\
(110.17) \\
N=60\end{array}$ & $\begin{array}{c}245.89 \\
(126.28) \\
N=65\end{array}$ & $\begin{array}{c}227.70 \\
(119.86) \\
N=125\end{array}$ & 0.0638 \\
\hline & both & $\begin{array}{c}197.10 \\
(107.90) \\
N=69\end{array}$ & $\begin{array}{c}261.67 \\
(159.09) \\
N=69\end{array}$ & $\begin{array}{c}229.38 \\
(139.25) \\
N=138\end{array}$ & 0.0069 \\
\hline
\end{tabular}

Table 8: Mean values, standard deviations (in parentheses) and number of observations for number of total participants by period, region and journal. Last column is the p-value from a two-sided Mann-Whitney test.

\subsection{Ex Ante Proxies for a Paper's Quality}

Ex ante proxies represent information that is available before the paper is accepted for publication. Thus, such proxies can be used by referees and editors when deciding about whether to accept or reject a submitted paper. Our four proxies, P1 to P4, are such ex ante proxies. However, aspects like novelty, originality, and practical relevance are also available ex ante and important for a paper's quality. Attempting to account for such additional ex ante 
proxies, we include three additional variables: the number of pages, the number of references, and authors' reputation. When testing for editorial favoritism (in section 6), we will control for these variables.

(P5) Consistent with the results of Medoff (2003) and Laband and Piette (1994a) we expect a positive correlation between the number of pages and quality. We assume that editors are willing to allocate more journal space to high quality papers. Since the journals have different formats and therefore different numbers of words per page, whenever necessary we converted the number of pages into EE-equivalent pages.

(P6) We expect a positive correlation between the number of references and quality. We assume that authors who cite a larger number of references have studied a larger amount of related literature before conducting their own research. As we explain in subsection 5.4 below, we use citations received in the 5 and 10 years after publication of a paper as a proxy for the ex post quality. It seems plausible that a paper with a higher number of references also receives more attention from the scientific community than a paper with only a small number of references.

(P7) As shown in Medoff (2003) and Laband and Piette (1994a) an author's reputation is likely to have a positive effect on the paper's quality. We proxy authors' reputation by their stock of citations. In case of a single author, we take the total number of citations received by the author during the 5 years prior to the publication of the paper. In case of more than one author, we take the average of all authors' citations during the 5 years prior to the publication of the paper ${ }^{19}$. Editors could take a scholar's stock of prior citations as a signal of the expected scientific contribution of her paper (see Medoff 2003, 428-429) ${ }^{20}$. Also, it is conceivable that, regardless of the paper's quality, papers authored by well-known economists tend to attract more citations (Merton's Matthew effect, see Merton 1968).

\footnotetext{
${ }^{19}$ The average number of authors increased significantly from the first period (1999-2003, mean: 2.30) to each of the three subsequent periods (2004-2008, mean: $2.54, p=0.034 ; 2009-2013$, mean: $2.66, p<0.01 ; 2014-2018$, mean: 2.53, $p=0.024$; $p$-values from two-sided Mann-Whitney tests). However, the increase is small and there are no significant differences in the average number of authors in the last three periods. We therefore assume that our measure of reputation is not distorted by changes in the average number of authors.

${ }^{20}$ This requires that editors can identify authors' identities despite the referee process being double blind. In a field experiment, Blank (1991) found that in AER's double blind referee process about $50 \%$ of referees could correctly identify the identity of authors. Given that many authors post preliminary versions of their papers online, we assume that in many cases, editors can also identify authors' identities.
} 


\subsection{Citations as Proxy for Ex Post Quality}

Ex post proxies measure the quality of a paper after its publication. We focus on just one proxy, citations $^{21}$. This does not imply that citations reflect a paper's true quality. Rather, we decided to use the number of citations because data on citations is widely available and is heavily used to allocate positions and resources (Card and DellaVigna forthcoming, Hamermesh 2018, Moed 2006, Laband and Piette 1994b). Moreover, assuming that it is a concern of the editors to maximize their journals' impact factor, they have an incentive to accept papers that they expect to receive a high number of citations.

Fehler! Verweisquelle konnte nicht gefunden werden. and Figure 2 show the distributions of citations received in the 5 and 10 years following publication by journal. Due to the small number of observations for the JEEA, we plot the distributions only for AER and EE (but see Table 9 for some descriptive statistics). The distributions are heavily skewed to the right. As one would expect, laboratory experiments published in the AER receive significantly more citations than laboratory experiments published in EE.
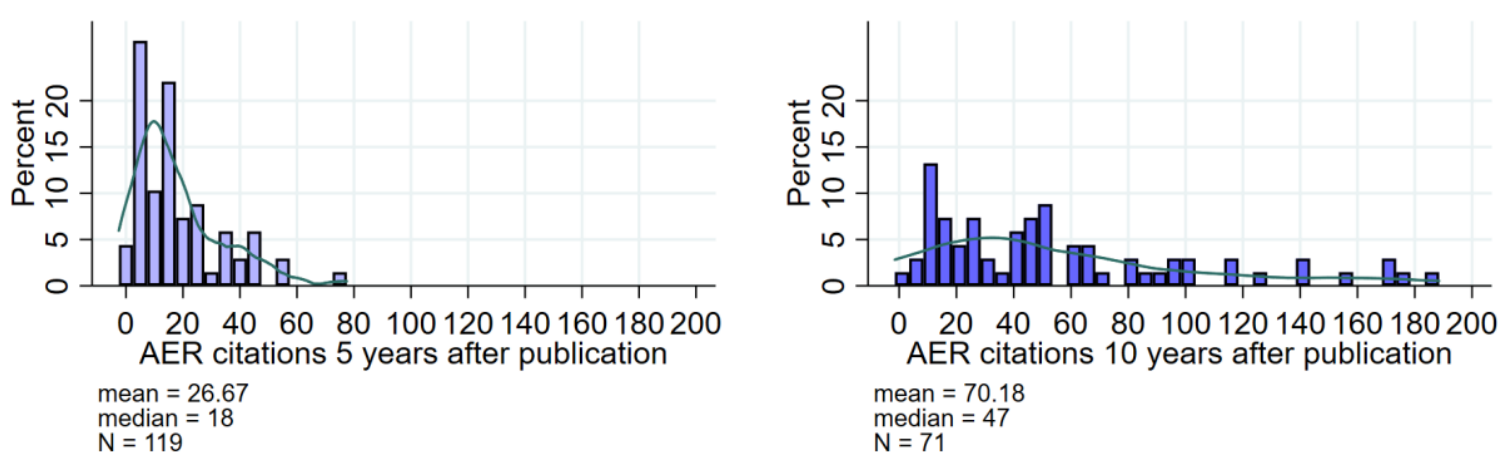

Figure 1: Distribution of citations for laboratory experiments published in the AER, 5 and 10 years after publication.

${ }^{21}$ Other ex post proxies are being reprinted in anthologies or the amount of media-coverage. 

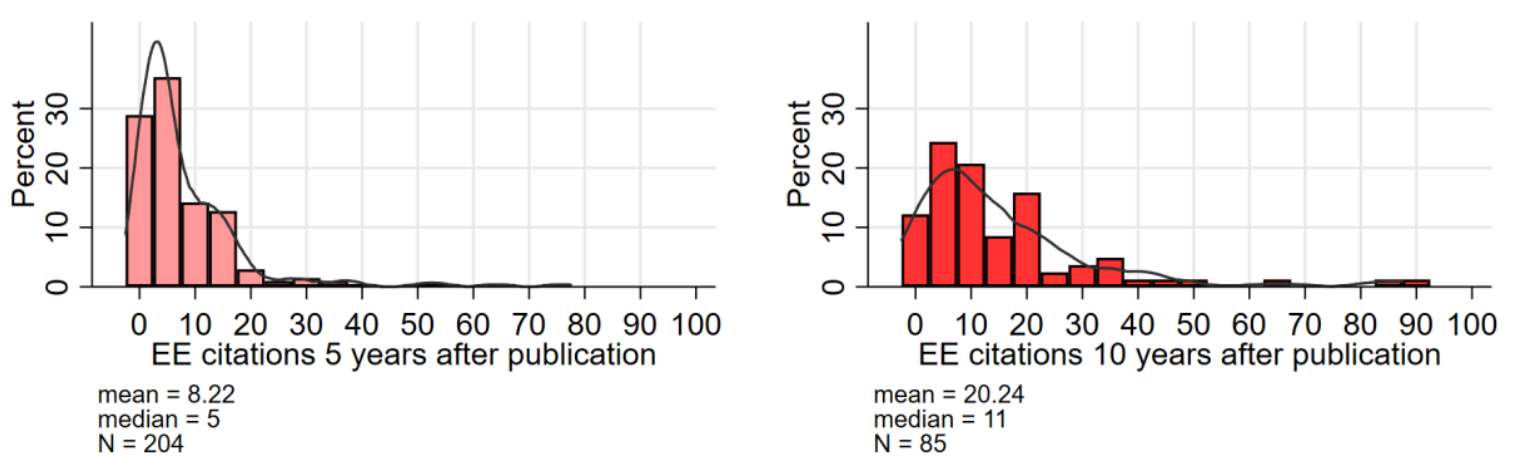

Figure 2: Distribution of citations for laboratory experiments published in EE, 5 and 10 years after publication.

\subsection{Are there Differences in Citations?}

Subsection 5.2 showed that North American and European experiments differ with respect to the total number of participants (P1) and the number of participants per treatment (P2). One might wonder whether this difference is associated with a difference in ex post quality, i.e., the number of citations. If there is a positive correlation between the total number of participants or the number of participants per treatment and the experiment's quality, one would expect that European experiments receive a higher number of citations on average.

Table 9 and Table 10 show that laboratory experiments conducted in Europe receive more citations compared to laboratory experiments conducted in North America. For the 5-year period after publication, this holds for all three journals and for the 10-year period after publication this holds for papers published in the AER and EE. For JEEA, there are too few observations because JEEA started only in 2003.

Most differences for mean values are statistically significant, and, more importantly, they are very large. For example, looking at citations in the 10 years after publication for experiments published in the AER, we see that European experiments received on average 124 citations while North American experiments received on average 61 citations. Since citations are heavily skewed to the right we also perform a test for differences in medians in Table 9 and Table 10. There are only significant differences in medians for citations received in the 5 years after publication for laboratory experiments published in the AER and EE. 


\begin{tabular}{|c|c|c|c|c|c|}
\hline \multicolumn{2}{|c|}{$\begin{array}{l}\text { citations five } \\
\text { years after } \\
\text { publication }\end{array}$} & North America & Europe & both regions & $p$-value \\
\hline AER & $\begin{array}{c}\text { mean } \\
\text { median } \\
90 \%-\mathrm{p} . \\
\mathrm{sd} \\
N\end{array}$ & $\begin{array}{c}23.63 \\
17.00 \\
61.00 \\
(23.15) \\
65\end{array}$ & $\begin{array}{c}38.62 \\
31.50 \\
82.00 \\
(34.82) \\
34\end{array}$ & $\begin{array}{c}28.78 \\
20.00 \\
65.00 \\
(28.45) \\
99\end{array}$ & $\begin{array}{c}0.0045 \\
0.034\end{array}$ \\
\hline $\mathrm{EE}$ & $\begin{array}{c}\text { mean } \\
\text { median } \\
90 \%-\text { p. } \\
\text { sd } \\
N\end{array}$ & $\begin{array}{c}6.20 \\
4.00 \\
15.50 \\
(7.87) \\
80\end{array}$ & $\begin{array}{c}10.62 \\
6.00 \\
23.00 \\
(13.03) \\
87 \\
\end{array}$ & $\begin{array}{c}8.50 \\
4.00 \\
17.00 \\
(11.06) \\
167\end{array}$ & $\begin{array}{c}0.0039 \\
0.007\end{array}$ \\
\hline JEEA & $\begin{array}{c}\text { mean } \\
\text { median } \\
90 \%-\text { p. } \\
\text { sd } \\
N \\
\end{array}$ & $\begin{array}{c}22.13 \\
12.50 \\
83.00 \\
(26.01) \\
8 \\
\end{array}$ & $\begin{array}{c}29.00 \\
9.00 \\
160.00 \\
(50.10) \\
9 \\
\end{array}$ & $\begin{array}{c}25.76 \\
12.00 \\
83.00 \\
(39.54) \\
17 \\
\end{array}$ & $\begin{array}{c}0.7726 \\
0.797\end{array}$ \\
\hline $\begin{array}{l}\text { all } \\
\text { three }\end{array}$ & $\begin{array}{c}\text { mean } \\
\text { median } \\
90 \%-p . \\
\text { sd } \\
N\end{array}$ & $\begin{array}{c}14.44 \\
7.00 \\
36.00 \\
(19.08) \\
153\end{array}$ & $\begin{array}{c}19.22 \\
10.50 \\
46.00 \\
(27.10) \\
130\end{array}$ & $\begin{array}{c}16.63 \\
9.00 \\
40.00 \\
(23.19) \\
283\end{array}$ & $\begin{array}{c}0.0696 \\
0.097\end{array}$ \\
\hline
\end{tabular}

Table 9: Mean values, medians, $90 \%$ percentiles, standard deviations (in parentheses) and number of observations for citations in the 5 years after publication ('c5') by region and journal. The upper (lower) row of the last column contains the $p$-values of a two-sample Mann-Whitney test (continuity corrected Pearson Chi-square test), comparing the distribution of $\mathrm{c} 5$ between North America and Europe. 


\begin{tabular}{|c|c|c|c|c|c|}
\hline \multicolumn{2}{|c|}{$\begin{array}{l}\text { citations ten } \\
\text { years after } \\
\text { publication }\end{array}$} & North America & Europe & both regions & $p$-value \\
\hline AER & $\begin{array}{c}\text { mean } \\
\text { median } \\
90 \%-\mathrm{p} . \\
\mathrm{sd} \\
N\end{array}$ & $\begin{array}{c}61.28 \\
44.00 \\
128.00 \\
(75.44) \\
43\end{array}$ & $\begin{array}{c}123.62 \\
101.00 \\
275.00 \\
(106.33) \\
13\end{array}$ & $\begin{array}{c}75.75 \\
49.50 \\
171.00 \\
(86.71) \\
56\end{array}$ & $\begin{array}{c}0.0170 \\
0.527\end{array}$ \\
\hline $\mathrm{EE}$ & $\begin{array}{c}\text { mean } \\
\text { median } \\
90 \%-\text { p. } \\
\text { sd } \\
N\end{array}$ & $\begin{array}{c}13.55 \\
9.00 \\
27.00 \\
(15.07) \\
42\end{array}$ & $\begin{array}{c}33.57 \\
14.00 \\
88.00 \\
(45.69) \\
23\end{array}$ & $\begin{array}{c}20.63 \\
11.00 \\
43.00 \\
(30.92) \\
65\end{array}$ & $\begin{array}{c}0.0511 \\
0.541\end{array}$ \\
\hline JEEA & $\begin{array}{c}\text { mean } \\
\text { median } \\
90 \%-\text { p. } \\
\text { sd } \\
N\end{array}$ & $\begin{array}{c}8.00 \\
8.00 \\
8.00 \\
1\end{array}$ & $\begin{array}{c}31.50 \\
31.50 \\
46.00 \\
(20.51) \\
2\end{array}$ & $\begin{array}{c}23.67 \\
17.00 \\
46.00 \\
(19.86) \\
3\end{array}$ & $\begin{array}{c}\text { not } \\
\text { enough } \\
\text { oberv. }\end{array}$ \\
\hline both & $\begin{array}{c}\text { mean } \\
\text { median } \\
90 \%-\text { p. } \\
\text { sd } \\
N\end{array}$ & $\begin{array}{c}37.69 \\
19.00 \\
86.00 \\
(59.44) \\
85\end{array}$ & $\begin{array}{c}66.08 \\
35.00 \\
176.00 \\
(84.34) \\
36\end{array}$ & $\begin{array}{c}46.14 \\
21.00 \\
118.00 \\
(68.68) \\
121\end{array}$ & $\begin{array}{c}0.0807 \\
0.311\end{array}$ \\
\hline
\end{tabular}

Table 10: Mean values, medians, $90 \%$ percentiles, standard deviations (in parentheses) and number of observations for citations in the 10 years after publication ('c10') by region and journal. The upper (lower) row of the last column contains the $p$-values of a two-sample Mann-Whitney test (continuity corrected Pearson Chi-square test), comparing the distribution of $\mathrm{c} 10$ between North America and Europe.

\section{Citations, Quality Proxies and Editorial Favoritism}

In this section, we examine whether the differences in citations are driven by differences in the quality proxies $\mathrm{P} 1$ to $\mathrm{P} 7$ or if they are indicative of editorial favoritism, which could result from the US dominance, as described in sections 4.1 and 4.2.

\subsection{Editorial Favoritism}

With regard to the quality proxies discussed in subsection 5.1, there is no reason to assume that clearly defined standards exist. Without such clearly defined standards, editors have a lot of leeway. Also, the proxies do not capture a paper's originality and relevance. Originality and relevance are highly subjective and might be unknown to editors when deciding about publication. This makes it possible that non-scientific criteria can have an influence on editors' 
decisions, thus facilitating discrimination. Possibly, the US dominance itself even results from the behavior of editors, whose decisions are influenced by non-scientific criteria ${ }^{22}$.

In order to see if there is editorial favoritism in experimental economics, we use an analysis similar to Medoff (2003) and Laband and Piette (1994a). Unlike Medoff (2003) and Laband and Piette (1994a), we do not focus on a single year of publication but a period of several years. In the existing literature (Colussi 2018, Brogaard et al. 2014, Medoff 2003, Laband and Piette 1994a) there are multiple methods for measuring social ties. For our analysis we do not consider social ties between authors and editorial board members at the institutional level. Instead, our measure of social ties is the share of authors with a US affiliation ${ }^{23}$. More specifically, we test the hypothesis that for AER papers, the share of US-affiliated authors is negatively correlated with the number of citations.

If confirmed, this would indicate that there is editorial favoritism in the AER. We hypothesize editorial favoritism for the AER, because almost all members of AER's editorial board are affiliated with a North American institution ${ }^{24}$. We do not hypothesize editorial favoritism for EE and the JEEA, because only half of their editorial boards consist of North Americanaffiliated economists ${ }^{25}$.

\footnotetext{
${ }^{22}$ Other reasons for the US dominance are mentioned in Frey and Pommerehne (1998). Firstly, the social and political conditions for research are very good in the US, leading to immigration of skilled researchers into the US. Secondly, the incentives for good research (in terms of publications in top journals) are very strong in the US. And thirdly, language. Papers published in a language other than English will rarely receive the same amount of attention like papers published in English because English is the lingua franca of economics. For economists whose native language is not English, publishing in English is associated with higher costs because one has to adopt language, style and format common in the US. We believe that these reasons have become weaker during the last years.

${ }^{23}$ Laband and Piette (1994a: 201) note that a broad range of social ties between editors and authors are not included in their analysis. Due to this fact and due to our long observation period, we are confident that our measure of social ties is suitable to show possible effects of editorial favoritism.

${ }^{24}$ AER's editorial board consists of 77 individuals, serving as editor, coeditor or board member. 72 individuals $(93.50 \%)$ are affiliated with a North American-institution. Out of the five remaining individuals, three received their PhDs from US universities (https://www.aeaweb.org/journals/aer/about-aer/editors, accessed May 22, 2019). ${ }^{25}$ EE's editorial board consists of 59 individuals, serving as editor, advisory editor or member of the editorial board. 28 individuals $(47.46 \%)$ are affiliated with North American-institutions. The rest of the editorial board includes 23 individuals (38.98\%) with a European affiliation, 6 individuals with an affiliation in Australia or New Zealand and one individual each with an affiliation in Asia or South America (https://www.springer.com/economics/economic+theory/journal/10683?detailsPage=editorialBoard, accessed May 22, 2019). JEEA's editorial board consists of 72 individuals, serving as editor, associate editor or member of the advisory board. 37 individuals are affiliated with a European institution, 34 individuals are affiliated with a North-American institution and one individual is affiliated with an institution in Asia (https://www.eeassoc.org/index.php?site=JEEA\&page=175\&trsz=45, accessed October 1, 2019).
} 
In order to test our hypothesis, we use the following regression models.

Models 1 and 4:

$c_{i}(5,10)=\beta_{0}+\beta_{1} S T_{i}+\gamma_{5} P 5_{i}+\gamma_{6} P 6_{i}+\gamma_{7} P 7_{i}+\delta_{i} P \& P_{i}+u_{i}$

Models 2 and 5:

$c_{i}(5,10)=\beta_{0}+\beta_{1} S T_{i}+\gamma_{1} P 1_{i}+\gamma_{4} P 4_{i}+\gamma_{5} P 5_{i}+\gamma_{6} P 6_{i}+\gamma_{7} P 7_{i}+\delta_{i} P \& P_{i}+u_{i}$

Models 3 and 6:

$$
\begin{aligned}
c_{i}(5,10)= & \beta_{0}+\beta_{1} S T_{i}+\gamma_{2} P 2_{i}+\gamma_{3} P 3_{i}+\gamma_{4} P 4_{i}+\gamma_{5} P 5_{i}+\gamma_{6} P 6_{i}+\gamma_{7} P 7_{i}+ \\
& \delta_{i} P \& P_{i}+u_{i}
\end{aligned}
$$

The independent variables $c_{i}(5)$ and $c_{i}(10)$ represent the total number of citations paper $i$ received during the 5 or 10 years after publication. Because the number of citations is leftcensored by 0 , we used Tobit regressions. Note that data on $c_{i}(5)\left(c_{i}(10)\right)$ is available only for papers published in 2013 (2008) or earlier.

Our measure of social ties, $S T_{i}$, is the relative share of US-affiliated authors for paper $i^{26}$. The coefficient $\beta_{1}$ estimates the difference in quality (measured by the number of citations) between AER papers authored by scholars with and without a US-affiliation. In the presence of editorial favoritism, we expect $\beta_{1}<0$.

The paper's quality proxies number of pages (P5), number of references (P6) and authors' reputation (P7) are included in each model specification. Models 1 and 4 include only these proxies. In models 2 and 5, we add the total number of participants (P1) and the strength of incentives (P4). In models 3 and 6, we add the number of participants per treatment (P2), the number of treatments (P3), and the strength of incentives (P4). Based on sections 5.1 and 5.3, we expect all proxies' coefficients to be positive. For the AER regressions, $P \& P_{i}$ is an indicator

\footnotetext{
${ }^{26}$ This is different from Laband and Piette (1994a) and Medoff (2003) who focus on authors who received their $\mathrm{PhDs}$ from the same university the editor was affiliated with at the time of the publication. We focus on US versus non-US-affiliations because the AER has several rules that prevent editorial favoritism on the level of institutions. For example, "[c]oeditors are recused from papers involving current colleagues at the same institution (regardless of department), as well as graduate students at the same institution" (for all rules see: https://www.aeaweb.org/journals/aer/about-aer/editorial-policy). We excluded papers $(N=7)$ reporting laboratory experiments conducted in the US by authors that do not have an affiliation in the US, because for these papers it is unclear whether a social tie exists.
} 
variable for papers published in AER's Papers and Proceedings, which we include in models 1 to 6 .

\begin{tabular}{|c|c|c|c|c|c|c|}
\hline & $\begin{array}{l}(1) \\
\text { c5 }\end{array}$ & $\begin{array}{l}(2) \\
\text { c5 }\end{array}$ & $\begin{array}{l}\text { (3) } \\
\text { c5 }\end{array}$ & $\begin{array}{l}\text { (4) } \\
\text { c10 }\end{array}$ & $\begin{array}{l}(5) \\
\text { c10 }\end{array}$ & $\begin{array}{l}\text { (6) } \\
\text { c10 }\end{array}$ \\
\hline Constant & $\begin{array}{l}18.75^{* *} \\
(8.60)\end{array}$ & $\begin{array}{l}26.20 \\
(18.52)\end{array}$ & $\begin{array}{l}29.10 \\
(20.99)\end{array}$ & $\begin{array}{c}139.90^{* * * *} \\
(38.04)\end{array}$ & $\begin{array}{l}219.50^{* * *} \\
(68.00)\end{array}$ & $\begin{array}{c}283.46^{* * * *} \\
(77.83)\end{array}$ \\
\hline ST & $\begin{array}{l}-7.70 \\
(5.45)\end{array}$ & $\begin{array}{c}-18.03^{*} \\
(9.67)\end{array}$ & $\begin{array}{l}-19.86^{*} \\
(10.26)\end{array}$ & $\begin{array}{l}-44.91^{*} \\
(25.61)\end{array}$ & $\begin{array}{c}-101.30^{* *} \\
(35.77)\end{array}$ & $\begin{array}{c}-141.80^{* * * *} \\
(37.08)\end{array}$ \\
\hline \multicolumn{7}{|l|}{$\begin{array}{l}\text { Experiment } \\
\text { Quality }\end{array}$} \\
\hline $\begin{array}{l}\text { P1 } \\
\text { (total nr. of part.) }\end{array}$ & & $\begin{array}{l}-0.01 \\
(0.02)\end{array}$ & & & $\begin{array}{l}-0.01 \\
(0.07)\end{array}$ & \\
\hline $\begin{array}{l}\mathrm{P} 2 \\
\text { (part. per treatm.) }\end{array}$ & & & $\begin{array}{l}-0.04 \\
(0.03)\end{array}$ & & & $\begin{array}{l}-0.20^{*} \\
(0.10)\end{array}$ \\
\hline $\begin{array}{l}\text { P3 } \\
\text { (treatments) }\end{array}$ & & & $\begin{array}{l}-0.91 \\
(1.61)\end{array}$ & & & $\begin{array}{l}-3.37 \\
(8.09)\end{array}$ \\
\hline $\begin{array}{l}\text { P4 } \\
\text { (incentives) }\end{array}$ & & $\begin{array}{c}-2.70 \\
(15.35)\end{array}$ & $\begin{array}{c}-2.47 \\
(15.84)\end{array}$ & & $\begin{array}{l}-18.85 \\
(45.24)\end{array}$ & $\begin{array}{l}-37.74 \\
(45.85)\end{array}$ \\
\hline \multicolumn{7}{|l|}{ Paper Quality } \\
\hline $\begin{array}{l}\text { P5 } \\
\text { (pages) }\end{array}$ & $\begin{array}{l}-0.40 \\
(0.28)\end{array}$ & $\begin{array}{l}-0.17 \\
(0.50)\end{array}$ & $\begin{array}{l}-0.08 \\
(0.52)\end{array}$ & $\begin{array}{l}-2.16 \\
(1.30)\end{array}$ & $\begin{array}{l}-0.68 \\
(2.33)\end{array}$ & $\begin{array}{l}-0.50 \\
(2.87)\end{array}$ \\
\hline $\begin{array}{l}\text { P6 } \\
\text { (references) }\end{array}$ & $\begin{array}{c}0.64^{* * * *} \\
(0.17)\end{array}$ & $\begin{array}{c}0.50^{*} \\
(0.28)\end{array}$ & $\begin{array}{c}0.49^{*} \\
(0.28)\end{array}$ & $\begin{array}{c}0.60 \\
(0.90)\end{array}$ & $\begin{array}{l}-2.12 \\
(1.31)\end{array}$ & $\begin{array}{l}-2.67 \\
(1.60)\end{array}$ \\
\hline $\begin{array}{l}\text { P7 } \\
\text { (reputation) }\end{array}$ & $\begin{array}{l}0.02^{* *} \\
(0.01)\end{array}$ & $\begin{array}{c}0.02 \\
(0.01)\end{array}$ & $\begin{array}{c}0.02 \\
(0.01)\end{array}$ & $\begin{array}{c}0.03 \\
(0.09)\end{array}$ & $\begin{array}{c}0.11 \\
(0.24)\end{array}$ & $\begin{array}{c}0.26 \\
(0.29)\end{array}$ \\
\hline Papers\&Proceed. & $\begin{array}{l}-11.73 \\
(8.22)\end{array}$ & $\begin{array}{c}-8.35 \\
(17.79)\end{array}$ & $\begin{array}{c}-6.25 \\
(19.88)\end{array}$ & $\begin{array}{l}-67.22^{* *} \\
(29.34)\end{array}$ & $\begin{array}{l}-49.16 \\
(58.94)\end{array}$ & $\begin{array}{l}-60.06 \\
(62.62)\end{array}$ \\
\hline $\begin{array}{l}N \\
\text { Pseudo } \mathrm{R}^{2}\end{array}$ & $\begin{array}{c}118 \\
0.03\end{array}$ & $\begin{array}{c}61 \\
0.02\end{array}$ & $\begin{array}{c}59 \\
0.02\end{array}$ & $\begin{array}{c}70 \\
0.01\end{array}$ & $\begin{array}{c}26 \\
0.03\end{array}$ & $\begin{array}{c}25 \\
0.05\end{array}$ \\
\hline
\end{tabular}

Table 11: Tobit regressions of $\mathrm{c}(5)$ and $\mathrm{c}(10)$ on papers' and experiments' quality proxies. AER papers. Standard errors in parentheses: $* \mathrm{p}<0.10, * * \mathrm{p}<0.05, * * * \mathrm{p}<0.01$.

Table 11 contains the regression results for papers published in the AER. Taking the number of citations in the 5 years after publication as a proxy for quality, we find a significant negative effect of social ties for models 2 and $3\left(\beta_{1}<0\right)$. This suggests that papers from authors with stronger social ties (i.e., a larger share of US-affiliated authors) have a lower quality compared to papers from authors with affiliations outside the US. More precisely, $\beta_{1}$ measures the difference in citations between a paper with solely US-affiliated authors and a paper without 
any US-affiliated authors. Based on model 2, papers with solely US-affiliated authors receive 18 citations less in the 5 years after publication. Model 3 predicts a similar effect. The results are even stronger when we take the number of citations in the 10 years after publication as a proxy for quality (models 4 to 6). On average, papers with solely US-affiliated authors receive between 45 and 142 citations less compared to papers without any US-affiliated authors ${ }^{27}$.

This difference can be interpreted as indirect evidence for discrimination, which would indicate that a paper from a US-based author is accepted for publication when a higher-quality paper from an author with an affiliation outside the US is available. Of course, this only holds if highquality papers from authors without social ties to the editorial board were submitted and rejected, but given AER's rejection rate, we think that this is highly likely ${ }^{28}$.

This, however, does not imply that editors consciously discriminate against authors from outside the US. Rather, it is possible that editors systematically mispredict the number of citations a paper will receive in the years following its publication (i.e., editors wrongly predict that papers authored by US-based economists receive more citations than they actually do). Nonetheless, if citations can be taken as a proxy for quality, this will slow down scientific progress, and editors will fail to maximize their journal's impact factor.

\subsection{How do the Quality Proxies of AER Papers Affect Citations?}

Regarding the proxies for experimental quality (P1 to $\mathrm{P} 4)$, only the number of participants per treatment $(\mathrm{P} 2)$ affects citations. For each model, the total number of participants $(\mathrm{P} 1)$, the number of treatments (P3), and the strength of monetary incentives (P4) have no effect on the number of citations in the 5 or 10 years after publication. This does not imply that editors do not care about the experiments' quality proxies. Rather, it could be that there are minimum standards that have to be fulfilled in order to get published, but going beyond those standards does not increase experimental quality any further. In other words, the perceived quality of an

\footnotetext{
${ }^{27}$ As a robustness check, we test how our results from subsections 6.1 to 6.3 change if we use another proxy for social ties (see Table 18 and Table 19 in the appendix). Instead of $S T_{i}$ we introduce an indicator variable that takes a value of 1 if all experiments included in a paper have been carried out exclusively in the US. For models 2, 3, 5 and 6 in Table 18 (AER) and for models 1, 2, 3 and 4 in Table 19 (EE) we see that experiments conducted in North America receive significantly fewer citations in the 5 and 10 years after publication. The results for the quality characteristics (P1 to P7) are qualitatively similar.

${ }^{28}$ In 2018, for example, only 5.85\% of all submissions were accepted at the AER (Duflo 2019). Medoff (2003, 427) discusses several reasons why it is problematic to infer a possible editorial favoritism from the acceptance rates of a journal.
} 
experiment that has a sufficient number of treatments and sufficiently strong incentives might not increase by adding additional treatments or paying higher incentives.

In model 6 in Table 11, the number of participants per treatment $(\mathrm{P} 2)$ is statistically significant but negative - contrary to what we expected. Why should a paper's quality decrease when the number of participants per treatment increases? Finding a smaller effect requires an experiment with a larger number of participants per treatment. Thus, if there is an inverse relation between quality and effect size, possibly because smaller effects are perceived as less interesting, this could explain the negative effect.

Next, we look at the paper's quality proxies (P5 to P7). The number of pages (P5) has no effect on citations. Taking the number of citations in the 5 years after publication as a proxy for quality, the number of references (P6) has a robust effect. Approximately 1.5 to 2 additional references yield one additional citation. Only in model 1, the author's reputation (P7) has a significant but small effect. For 50 citations an author has accumulated in the 5 years prior publication, the expected number of citations increases by $1^{29}$. However, if we take citations in the 10 years after publication as dependent variable, the author's reputation has no effect.

It seems that if the paper's quality proxies have any effects on citations, there are positive effects for citations during the 5 years after publication, but no effects for citations during the 10 years after publication. Possibly, the number of references (P6) and the author's reputation (P7) attract some attention to the paper, and this increased attention leads to more citations, but this effect vanishes as the paper grows older.

\subsection{How do the Quality Proxies of EE and JEEA Papers Affect Citations?}

In Table 12 and Table 13, we report the main results for papers published in EE and the JEEA respectively.

\footnotetext{
${ }^{29}$ Note that our proxy for reputation (the number of citations an author has received in the 5 years before the paper's publication) is left-skewed (see Figure 3 and Figure 4 in the appendix). For AER-papers from North America (Europe), the median is 72 (88) and the mean is 138 (244). This reflects Merton's Matthew effect. Those who already have large number of citations receive more citations.
} 


\begin{tabular}{|c|c|c|c|c|c|c|}
\hline & $\begin{array}{l}\text { (1) } \\
\text { c5 }\end{array}$ & $\begin{array}{l}(2) \\
c 5\end{array}$ & $\begin{array}{l}(3) \\
c 5\end{array}$ & $\begin{array}{l}\text { (4) } \\
\text { c10 }\end{array}$ & $\begin{array}{l}5) \\
\text { c10 }\end{array}$ & $\begin{array}{l}\text { (6) } \\
\text { c10 }\end{array}$ \\
\hline Constant & $\begin{array}{l}8.18^{* * * *} \\
(2.61)\end{array}$ & $\begin{array}{l}6.42^{*} \\
(3.32)\end{array}$ & $\begin{array}{l}5.53 \\
(3.69)\end{array}$ & $\begin{array}{l}31.57^{* * *} \\
(12.85)\end{array}$ & $\begin{array}{c}12.86 \\
(16.91)\end{array}$ & $\begin{array}{c}-2.77 \\
(17.35)\end{array}$ \\
\hline ST & $\begin{array}{l}-2.44 \\
(1.58)\end{array}$ & $\begin{array}{l}-1.88 \\
(1.72)\end{array}$ & $\begin{array}{l}-1.86 \\
(1.71)\end{array}$ & $\begin{array}{l}-10.80 \\
(7.32)\end{array}$ & $\begin{array}{l}-3.43 \\
(9.44)\end{array}$ & $\begin{array}{l}-10.89 \\
(9.11)\end{array}$ \\
\hline \multicolumn{7}{|l|}{$\begin{array}{l}\text { Experiment } \\
\text { Quality }\end{array}$} \\
\hline $\begin{array}{l}\text { P1 } \\
\text { (total nr. of part.) }\end{array}$ & & $\begin{array}{c}0.00 \\
(0.01)\end{array}$ & & & $\begin{array}{l}0.08^{*} \\
(0.05)\end{array}$ & \\
\hline $\begin{array}{l}\mathrm{P} 2 \\
\text { (part. per treatm.) }\end{array}$ & & & $\begin{array}{c}0.00 \\
(0.02)\end{array}$ & & & $\begin{array}{c}0.06 \\
(0.15)\end{array}$ \\
\hline $\begin{array}{l}\text { P3 } \\
\text { (treatments) }\end{array}$ & & & $\begin{array}{c}0.57 \\
(0.37)\end{array}$ & & & $\begin{array}{l}7.30^{* * * *} \\
(2.23)\end{array}$ \\
\hline $\begin{array}{l}\text { P4 } \\
\text { (incentives) }\end{array}$ & & $\begin{array}{c}4.20 \\
(4.45)\end{array}$ & $\begin{array}{c}2.73 \\
(4.53)\end{array}$ & & $\begin{array}{l}18.00 \\
(24.82)\end{array}$ & $\begin{array}{c}23.01 \\
(23.13)\end{array}$ \\
\hline \multicolumn{7}{|l|}{ Paper Quality } \\
\hline $\begin{array}{l}\text { P5 } \\
\text { (pages) }\end{array}$ & $\begin{array}{c}-0.44^{* * * *} \\
(0.13)\end{array}$ & $\begin{array}{c}-0.43^{* * *} \\
(0.13)\end{array}$ & $\begin{array}{l}-0.44^{* * *} \\
(0.13)\end{array}$ & $\begin{array}{l}-1.24^{* *} \\
(0.59)\end{array}$ & $\begin{array}{l}-1.40^{*} \\
(0.69)\end{array}$ & $\begin{array}{l}-1.01 \\
(0.65)\end{array}$ \\
\hline $\begin{array}{l}\text { P6 } \\
\text { (references) }\end{array}$ & $\begin{array}{c}0.27^{* * * *} \\
(0.06)\end{array}$ & $\begin{array}{l}0.20^{* * * *} \\
(0.07)\end{array}$ & $\begin{array}{l}0.21^{* * *} \\
(0.07)\end{array}$ & $\begin{array}{l}0.57^{* *} \\
(0.28)\end{array}$ & $\begin{array}{l}0.63^{*} \\
(0.35)\end{array}$ & $\begin{array}{c}0.50 \\
(0.33)\end{array}$ \\
\hline $\begin{array}{l}\text { P7 } \\
\text { (reputation) }\end{array}$ & $\begin{array}{l}0.01^{* * * *} \\
(0.01)\end{array}$ & $\begin{array}{l}0.03^{* * * *} \\
(0.01)\end{array}$ & $\begin{array}{l}0.03^{* * *} \\
(0.01)\end{array}$ & $\begin{array}{c}0.03 \\
(0.03)\end{array}$ & $\begin{array}{c}0.08 \\
(0.07)\end{array}$ & $\begin{array}{c}0.04 \\
(0.06)\end{array}$ \\
\hline $\begin{array}{l}N \\
\text { Pseudo } \mathrm{R}^{2}\end{array}$ & $\begin{array}{l}201 \\
0.02\end{array}$ & $\begin{array}{l}138 \\
0.03\end{array}$ & $\begin{array}{l}138 \\
0.03\end{array}$ & $\begin{array}{c}84 \\
0.01\end{array}$ & $\begin{array}{c}50 \\
0.02\end{array}$ & $\begin{array}{c}50 \\
0.04\end{array}$ \\
\hline
\end{tabular}

Table 12: Tobit regressions of $\mathrm{c}(5)$ and $\mathrm{c}(10)$ on social ties and experiments' and papers' quality proxies. EE papers. Standard errors in parentheses: $* \mathrm{p}<0.10, * * \mathrm{p}<0.05, * * * \mathrm{p}<0.01$.

As can be seen from Table 12, for EE papers the relative share of US-based authors (ST) has no significant effect on citations. The number of treatments (P3) has a positive effect on citations in the 10 years after publication. For each additional treatment, the expected number of citations increases by 7.30. The total number of participants (P1) has no effect on citations in the 5 years and a small positive effect on citations in the 10 years after publication. The number of participants per treatment $(\mathrm{P} 2)$ and the strength of monetary incentives $(\mathrm{P} 4)$ are not significant.

The number of references (P6) has a small but positive effect on citations in the 5 and 10 years after publication. The author's reputation (P7) has a small positive effect, but only on citations in the 5 years after publication. Finally, papers with a higher number of pages (P5) tend to 
receive fewer citations. Possibly, the non-significant effects of P1 to P4 stem from the fact that the distribution of citations in the 5 years after publication is much narrower for EE, compared to the AER and the JEEA (see Table 9).

\begin{tabular}{lccc}
\hline & $\mathbf{( 1 )}$ & $\mathbf{( 2 )}$ & $\mathbf{( 3 )}$ \\
& $\mathbf{c 5}$ & $\mathbf{c 5}$ & $\mathbf{c 5}$ \\
\hline Constant & -5.49 & 19.06 & -1.06 \\
& $(23.50)$ & $(26.52)$ & $(44.81)$ \\
ST & & & \\
& 18.29 & 18.75 & 37.27 \\
& $(25.82)$ & $(16.30)$ & $(29.68)$
\end{tabular}

\begin{tabular}{|c|c|c|c|}
\hline $\begin{array}{l}\text { Experiment } \\
\text { Quality }\end{array}$ & & & \\
\hline $\begin{array}{l}\text { P1 } \\
\text { (total nr. of part.) }\end{array}$ & & $\begin{array}{l}0.17^{* * * *} \\
(0.03)\end{array}$ & \\
\hline $\begin{array}{l}\mathrm{P} 2 \\
\text { (part. per treatm.) }\end{array}$ & & & $\begin{array}{l}0.55^{* *} \\
(0.21)\end{array}$ \\
\hline $\begin{array}{l}\text { P3 } \\
\text { (treatments) }\end{array}$ & & & $\begin{array}{c}4.64 \\
(3.53)\end{array}$ \\
\hline $\begin{array}{l}\text { P4 } \\
\text { (incentives) }\end{array}$ & & $\begin{array}{l}-68.10 \\
(52.46)\end{array}$ & $\begin{array}{l}-113.03 \\
(77.11)\end{array}$ \\
\hline Paper Quality & & & \\
\hline $\begin{array}{l}\text { P5 } \\
\text { (pages) }\end{array}$ & $\begin{array}{l}-1.40 \\
(1.01)\end{array}$ & $\begin{array}{l}-2.43^{* * *} \\
(0.60)\end{array}$ & $\begin{array}{l}-2.46^{* * *} \\
(0.98)\end{array}$ \\
\hline $\begin{array}{l}\text { P6 } \\
\text { (references) }\end{array}$ & $\begin{array}{l}1.55^{* *} \\
(0.67)\end{array}$ & $\begin{array}{l}0.99^{*} \\
(0.51)\end{array}$ & $\begin{array}{l}1.45 \\
(0.79)\end{array}$ \\
\hline $\begin{array}{l}\text { P7 } \\
\text { (reputation) }\end{array}$ & $\begin{array}{c}0.03 \\
(0.02) \\
\end{array}$ & $\begin{array}{l}0.02^{*} \\
(0.01) \\
\end{array}$ & $\begin{array}{l}0.03^{*} \\
(0.02)\end{array}$ \\
\hline$N$ & 19 & 13 & 13 \\
\hline Pseudo $\mathrm{R}^{2}$ & 0.04 & 0.19 & 0.11 \\
\hline
\end{tabular}

Table 13: Tobit regressions of $\mathrm{c}(5)$ on social ties and experiments' and papers' quality proxies. JEEA papers. Standard errors in parentheses: $* \mathrm{p}<0.10,{ }^{* *} \mathrm{p}<0.05,{ }^{* * *} \mathrm{p}<0.01$.

Table 13 shows that for papers published in the JEEA, the relative share of US-affiliated authors (ST) also has no significant effect on citations in the 5 years after publication. Note that Table 13 only reports the results for models 1 to 3 because there are only three laboratory experiments for which we have data on the citations in the 10 years after publication. The total number of participants $(\mathrm{P} 1)$ and the number of participants per treatment $(\mathrm{P} 2)$ each have a positive effect. The number of treatments (P3) and the strength of monetary incentives (P4) are not significant. 
For the JEEA the results for a papers' quality (P5 to P7) are very similar to the results for EE. In models 1 and 2 the number of references (P6) has a positive effect on citations in the 5 after publication. For the JEEA this effect is more pronounced than for EE. For models 2 and 3 also the author's reputation (P7) has a small positive effect on citations and papers with a higher number of pages (P5) tend to receive fewer citations.

Regarding the author's reputation (P7) for EE and the JEEA our results are in line with the results of Medoff (2003) and Laband and Piette (1994a). However, our results differ regarding the number of pages (P5), since Medoff (2003) and Laband and Piette (1994a) find that longer papers increase the number of citations.

\subsection{Network Effects as an Alternative Explanation}

Differences in citation practices and network effects could be an alternative explanation for the significantly lower number of citations received by US-affiliated authors in the AER. The majority of experimental economists (about $58 \%$ ) are affiliated in Europe ${ }^{30}$. If they are more familiar with each other's work, this could lead to a high number of citations from European authors to other European authors. Put bluntly, most experimental economists are in Europe, and if they cite each other, this increases the number of citations received by European economist but not by non-European economists. This is in line with Frey and Pommerehne $(1988,107)$, who argue that economists may tend to cite economists from the same country more often for personal or professional reasons, or simply because they know them best. If true, citations are a biased measure of quality. Moreover, the results from Table 11 might not be driven by the composition of AER's editorial board, but simply by network effects resulting from differences in citation practices and differences in the populations of experimental economists with a US- or European-affiliation.

To test this alternative explanation, we look at where citations come from. We selected the most cited papers from our dataset ${ }^{31}$ that were authored solely by economists with a US- (16 papers) or European-affiliation (11 papers), and analyzed where their received citations come from. The results show that the US-affiliated authors received on average $38.72 \%$ of their citations

\footnotetext{
${ }^{30}$ To get an idea of the total number of experimental economists in different regions, we checked the affiliations of all authors of the current RePEc list of authors in experimental economics $(N=1831)$. With $57.84 \%$, more than half of all experimental economists on this list have a European affiliation, followed by economists with an affiliation in North America (30.20\%), Asia (5.90\%), Australia or New Zealand (3.82\%), South America (1.86\%) and Africa (0.38\%). See, https://ideas.repec.org/i/eexp.html (accessed October 5, 2019).

${ }^{31}$ The criteria were that these papers received at least $40(100)$ citations in the 5 (10) years after publication.
} 
from North America, 50.42\% of their citations from Europe, and 10.86\% of their citations from the rest of the world. The respective numbers for the European-affiliated authors are $63.17 \%$ from Europe, $27.53 \%$ from North America and 9.31\% from the rest of the world.

The numbers for the European-affiliated authors thus almost match the geographical distribution of experimental economists on the RePEc list. Compared to the European-affiliated authors, the US-affiliated authors received a considerably lower share of their citations from Europe. This suggests that differences in citation practices and network effects that increase the citations of European-affiliated authors could at least partly drive our results. However, if differences in citation practices and network effects were solely responsible for our findings regarding ex post quality, we would expect a negative effect of social ties across all journals. As shown in Table 12 and Table 13, this is not the case. Moreover, the assumption that social ties between experimental economists in Europe are as strong as those between experimental economists in the US does not seem plausible. While the majority of US-affiliated authors are likely to be native English speakers, all of whom work within one country, our dataset for the European region includes authors with affiliations in 20 different countries. Only a few of the European-affiliated authors share the same mother tongue, and it is also likely that the European-affiliated authors will most frequently attend conferences and seminars at national level. For our dataset we therefore believe that social ties between US-affiliated authors are more pronounced than between European-affiliated authors.

\subsection{Limitations}

There are a number of limitations to our approach. First, we only collected data on laboratory experiments published in three journals. It is not clear whether a different journal selection would yield similar patterns on geographical concentration and the experiments' quality proxies. Despite the focus on three journals, we think that our results are noteworthy considering the ex ante and ex post quality differences between experiments conducted in North America and Europe.

Second, for the collection of citation data we used Web of Science. Since Web of Science has not indexed all journals and literature sources, the citations of Web of Science deviate from the citations counts by other platforms, e.g. Google Scholar ${ }^{32}$. For our data set we therefore do not

\footnotetext{
${ }^{32}$ See Hamermesh (2018) for a detailed analysis of the relation between Web of Science and Google Scholar citations.
} 
claim to have recorded all citations received by a paper in the years after its publication, or to have recorded all citations received by a single author in the 5 years prior publication of the respective paper. However, we do not regard this incomplete recording of citations as problematic, as it can be expected to introduce a level effect but not any systematic misrepresentations between authors.

Third, when testing for editorial favoritism, our data set contains only a small number of laboratory experiments published in the AER. This implies that our results must be interpreted with caution. Our results are compatible with the existence of editorial favoritism, but they do not prove its existence (see section 6.4). And, of course, there is no reason to believe that our results, which are based exclusively on papers reporting results from laboratory experiments, carry over to other subfields of economics. In addition, in our test for editorial favoritism, we assume that editors have the primary goal of maximizing the impact factor of their journal and thus the number of citations that the published papers receive. However, we can neither be sure that this assumption is correct nor that other quality characteristics, such as relevance for policymaking or expected media coverage, do not play a stronger role in the selection of papers.

Finally, it should be noted that we only recorded authors' affiliations at the time of publication. We have therefore not captured any social ties that existed due to previous employment, research or study stays.

\section{Conclusion}

In this paper, we examined geographical concentration, compared objectively measurable quality proxies and tested for editorial favoritism in experimental economics.

We found that geographical concentration decreased. More precisely, the US's share in research output decreased from $65 \%$ to $47 \%$ while the shares of several European countries (Germany, the Netherlands, Switzerland and the UK) and Australia increased. This is in line with other studies (Ek and Henrekson 2019, Kocher and Sutter 2001) that do not focus on any particular field but report a decreasing US dominance across fields.

Looking more closely into the papers, we examine if four ex ante proxies for the quality of the experiments (total number of participants, participants per treatment, number of treatments and strength of monetary incentives) differ between journals. 
Comparing experiments conducted in North America and Europe, there are no differences regarding the number of treatments and the strength of monetary incentives. However, European experiments rely on a significantly larger total number of participants and a significantly larger number of participants per treatment. This holds for all journals, but the difference is most pronounced for the AER, where, on average, experiments conducted in North America have 54 participants per treatment while experiments conducted in Europe have 111 participants per treatment.

The differences in the total number of participants and participants per treatment could reflect different methodological standards. However, they could also indicate substantial barriers to entry for European economists, especially at the AER, where the North American dominance is more pronounced in the composition of the editorial board.

Analyzing the number of citations papers receive in the 5 and 10 years after publication, we find that experiments conducted in Europe receive more citations compared to experiments conducted in North America. The differences are statistically significant and large, except for papers published in the JEEA, possibly because of the small number of observations for this journal. In the 10 years after publication, North American AER papers receive, on average, 61 citations while European AER papers receive, on average, 124 citations. For EE, the corresponding numbers are 14 and 34.

Finally, we test for editorial favoritism. Editorial favoritism means that social ties (here: a vast majority of members of the editorial board and a positive share of authors having a US affiliation) have a negative effect on the quality of the published papers. We focus on the AER, where almost all members of the editorial board are affiliated with US universities.

Our data provide some indications of editorial favoritism for the AER: papers authored by economists with a social tie to the editorial board receive between 18 (45) and 20 (142) fewer citations in the 5 (10) years after publication, compared to papers authored by economists without a social tie to the editorial board. Due to the higher number of experimental economists in Europe, network effects may at least partly drive these results. Nevertheless, network effects do not seem to be the whole explanation, since a positive share of US-affiliated authors of a paper has no negative effect on the citation counts of EE and JEEA papers.

For AER papers, we find only small or no effects of the experiment's quality proxies on citations. This could be due to the small number of observations. The number of references has 
a positive effect on citations in the 5 years but no respectively a negative effect on citations in the 10 years subsequent publication. For EE papers we find that the number of pages has a negative effect and that the number of references has a positive effect on citations in the 5 and 10 years after publication. Further, for EE papers our results show that authors' reputation has a positive effect on the number of citations only in the first 5 years after publication.

As a concluding remark: we found that about one third of the papers reported incomplete information about their experimental procedures. This is of particular concern in view of the replication crisis in the social sciences. Only a well-documented experiment can be replicated. In addition, the statistical processing of individual results in meta-studies is hampered if, for example, it is not clear how many persons participated in an experiment. Future research would benefit from clearly defined standards that specify which characteristics of a laboratory experiment should be reported in a paper. 


\section{References}

Abbink, K., \& Brandts, J. (2009). Collusion in growing and shrinking markets: empirical evidence from experimental duopolies. Experiments and Competition Policy, 34-60.

Afzal, U., d'Adda, G., Fafchamps, M., Quinn, S., \& Said, F. (2017). Two sides of the same rupee? Comparing demand for microcredit and microsaving in a framed field experiment in rural Pakistan. The Economic Journal, 128(614), 2161-2190.

Bardsley, N., Cubitt, R., Loomes, G., Moffat, P., Starmer, C., \& Sugden, R. (2010). Experimental economics: Rethinking the rules. Princeton University Press.

Bellemare, C., Bissonnette, L., \& Kröger, S. (2014). Statistical power of within and betweensubjects designs in economic experiments. IZA Discussion Paper No. 8583.

Bellemare, C., Bissonnette, L., \& Kröger, S. (2016). Simulating power of economic experiments: the powerBBK package. Journal of the Economic Science Association, 2(2), 157-168.

Blank, R. M. (1991). The effects of double-blind versus single-blind reviewing: Experimental evidence from the American Economic Review. American Economic Review, 1041-1067.

Brogaard, J., Engelberg, J., \& Parsons, C. A. (2014). Networks and productivity: Causal evidence from editor rotations. Journal of Financial Economics, 111(1), 251-270.

Camerer, C. F., Dreber, A., Forsell, E., Ho, T. H., Huber, J., Johannesson, M., Kirchler, M., Almenberg, J., Altmejd, A., Chan, T., Heikensten, E., Holzmeister, F., Imai, T., Isaksson, S., Nave, G., Pfeiffer, T., Razen, M. \& Wu, H. (2016). Evaluating replicability of laboratory experiments in economics. Science, 351(6280), 1433-1436.

Camerer, C. F., \& Hogarth, R. M. (1999). The effects of financial incentives in experiments: A review and capital-labor-production framework. Journal of Risk and Uncertainty, 19(1-3), $7-42$.

Card, D. \& DellaVigna, S. (forthcoming). What do editors maximize? Evidence from four leading economics journals. Review of Economics and Statistics.

Carpenter, J. P., Harrison, G. W., \& List, J. A. (Eds.). (2005). Field experiments in economics. Elsevier JAI.

Colussi, T. (2018). Social ties in academia: A friend is a treasure. Review of Economics and Statistics, 100(1), 45-50.

Combes, P. P., \& Linnemer, L. (2003). Where are the economists who publish? Publication concentration and rankings in Europe based on cumulative publications. Journal of the European Economic Association, 1(6), 1250-1308.

Czibor, E., Jimenez-Gomez, D., \& List, J. A. (2019). The Dozen Things Experimental Economists Should Do (More of) (No. w25451). National Bureau of Economic Research.

Davis, D. D., \& Holt, C. A. (1993). Experimental economics. Princeton university press. 
Drazen, A., Dreber, A., Ozbay, E. Y., \& Snowberg, E. (2019). A Journal-Based Replication of "Being Chosen to Lead". SSRN working paper.

Duflo, E. (2018). Report of the Editor: American Economic Review. AEA Papers and Proceedings, 108, 636-51.

Ek, S., \& Henrekson, M. (2019). The Geography and Concentration of Authorship in the Top Five: Implications For European Economics. Scottish Journal of Political Economy, 66(2), 215-245.

Elliott, C., Greenaway, D., \& Sapsford, D. (1998). Who's publishing who? The national composition of contributors to some core US and European journals. European Economic Review, 42(1), 201-206.

Frey, B., \& Pommerehne, W. (1988). The American domination among eminent economists. Scientometrics, 14(1-2), 97-110.

Guala, F. (2005). The methodology of experimental economics. Cambridge University Press.

Glötzl, F., \& Aigner, E. (2017). Six dimensions of concentration in economics: Scientometric evidence from a large-scale data set. Vienna University of Economics and Business, Working Paper Nr. 15.

Hamermesh, D. S. (1994). Facts and myths about refereeing. Journal of Economic Perspectives, 8(1), 153-163.

Hamermesh, D. S. (2018), Citations in economics: Measurement, uses, and impacts. Journal of Economic Literature, 56(1), 115-56.

Harrison, G. W., \& List, J. A. (2004). Field experiments. Journal of Economic Literature, 42(4), 1009-1055.

Heckman, J. (2017), Publishing and Promotion in Economics: The Curse of the Top Five, panel discussion at AEA meeting 2017.

[webcast: https://www.aeaweb.org/conference/webcasts/2017, slides: https://hceconomics.uchicago.edu/sites/default/files/file_uploads/AEA-Curse-FiveHO-SMALL-STATIC_2017-01-06d_jbb.pdf, accessed Aug 12, 2019]

Hertwig, R., \& Ortmann, A. (2001). Experimental practices in economics: A methodological challenge for psychologists?. Behavioral and Brain Sciences, 24(3), 383-403.

Hodgson, G. M., \& Rothman, H. (1999). The editors and authors of economics journals: a case of institutional oligopoly?. The Economic Journal, 109(453), 165-186.

Holt, C. A., \& Laury, S. K. (2002). Risk aversion and incentive effects. American Economic Review, 92(5), 1644-1655.

Imas, A. (2016). The realization effect: Risk-taking after realized versus paper losses. American Economic Review, 106(8), 2086-2109.

Ioannidis, J. P., Stanley, T. D., \& Doucouliagos, H. (2017). The power of bias in economics research. The Economic Journal 127(605), 236-265. 
Kalaitzidakis, P., Mamuneas, T. P., \& Stengos, T. (1999). European economics: An analysis based on publications in the core journals. European Economic Review, 43(4-6), 1150-1168.

Kocher, M. G., \& Sutter, M. (2001). The institutional concentration of authors in top journals of economics during the last two decades. The Economic Journal, 111(472), 405-421.

Laband, D. N., \& Piette, M. J. (1994a). Favoritism versus search for good papers: Empirical evidence regarding the behavior of journal editors. Journal of Political Economy, 102(1), 194-203.

Laband, D. N., \& Piette, M. J. (1994b). The relative impacts of economics journals: 19701990. Journal of Economic Literature, 32(2), 640-666.

Levitt, S. D., List, J. A., \& Sadoff, S. E. (2011). Checkmate: Exploring backward induction among chess players. American Economic Review, 101(2), 975-90.

Medoff, M. H. (2003). Editorial favoritism in economics?. Southern Economic Journal, 425434.

Merton, R. K. (1968). The Matthew effect in science: The reward and communication systems of science are considered. Science, 159(3810), 56-63.

Moed, H. F. (2006). Citation analysis in research evaluation (Vol. 9). Springer Science \& Business Media.

Moffatt, P. G. (2015). Experimetrics: Econometrics for experimental economics. Macmillan International Higher Education.

Neary, J. P., Mirrlees, J. A., \& Tirole, J. (2003). Evaluating economics research in Europe: An introduction. Journal of the European Economic Association, 1(6), 1239-1249.

Ortmann, A. (2009). The way in which an experiment is conducted is unbelievably important: On the experimentation practices of economists and psychologists. CESifo working paper No. 2887.

Read, D. (2005). Monetary incentives, what are they good for? Journal of Economic Methodology, 12(2), 265-276.

Rydval, O. \& Ortmann A. (2004). How financial incentives and cognitive abilities affect task performance in laboratory settings: An illustration. Economics Letters, 85(3), 315-320.

Shepherd, G. B. (1995). Rejected: Leading economists ponder the publication process. T. Horton and Doughters.

Stewart, N., Ungemach, C., Harris, A. J., Bartels, D. M., Newell, B. R., Paolacci, G., \& Chandler, J. (2015). The average laboratory samples a population of 7,300 Amazon

Mechanical Turk workers. Judgment and Decision Making, 10(5), 479-491.

Svorenčík, A. \& Maas H. (Eds.) (2016). The Making of Experimental Economics - Witness Seminar on the Emergence of a Field. Heidelberg, Springer.

Zhang, L. \& Ortmann A. (2013). Exploring the meaning of significance in experimental economics. UNSW Australian School of Business Research Paper, (2013-32). 


\section{Appendix}

\begin{tabular}{|c|c|c|c|c|}
\hline & \multicolumn{4}{|c|}{ Shares } \\
\hline & \multicolumn{4}{|c|}{ Scores } \\
\hline & AER & EE & JEEA & All three \\
\hline \multirow[t]{2}{*}{ Argentinia } & 0.54 & 0.00 & 0.00 & 0.18 \\
\hline & 2.73 & 0.00 & 0.00 & 2.73 \\
\hline \multirow[t]{2}{*}{ Australia } & 2.42 & 3.80 & 2.32 & 3.20 \\
\hline & 12.37 & 33.62 & 3.32 & 49.31 \\
\hline \multirow[t]{2}{*}{ Austria } & 2.81 & 4.86 & 0.00 & 3.73 \\
\hline & 14.35 & 42.99 & 0.00 & 57.34 \\
\hline \multirow[t]{2}{*}{ Azerbaijan } & 0.00 & 0.15 & 0.00 & 0.08 \\
\hline & 0.00 & 1.29 & 0.00 & 1.29 \\
\hline \multirow[t]{2}{*}{ Belgium } & 0.00 & 0.07 & 0.00 & 0.04 \\
\hline & 0.00 & 0.60 & 0.00 & 0.60 \\
\hline \multirow[t]{2}{*}{ Canada } & 1.62 & 2.71 & 1.71 & 2.25 \\
\hline & 8.27 & 23.98 & 2.44 & 34.70 \\
\hline \multirow[t]{2}{*}{ China } & 2.64 & 1.07 & 0.00 & 1.49 \\
\hline & 13.48 & 9.42 & 0.00 & 22.90 \\
\hline \multirow[t]{2}{*}{ Colombia } & 0.00 & 0.29 & 0.00 & 0.17 \\
\hline & 0.00 & 2.54 & 0.00 & 2.54 \\
\hline \multirow[t]{2}{*}{ Czech Republic } & 0.32 & 0.12 & 0.00 & 0.18 \\
\hline & 1.66 & 1.07 & 0.00 & 2.73 \\
\hline \multirow[t]{2}{*}{ Denmark } & 0.19 & 0.65 & 0.00 & 0.44 \\
\hline & 0.97 & 5.76 & 0.00 & 6.72 \\
\hline \multirow[t]{2}{*}{ Finland } & 0.00 & 0.13 & 0.00 & 0.07 \\
\hline & 0.00 & 1.13 & 0.00 & 1.13 \\
\hline \multirow[t]{2}{*}{ France } & 0.69 & 3.03 & 3.28 & 2.28 \\
\hline & 3.53 & 26.80 & 4.69 & 35.03 \\
\hline \multirow[t]{2}{*}{ Germany } & 4.35 & 12.08 & 11.62 & 9.47 \\
\hline & 22.20 & 106.85 & 16.62 & 145.67 \\
\hline \multirow[t]{2}{*}{ Guatemala } & 0.00 & 0.16 & 0.00 & 0.09 \\
\hline & 0.00 & 1.42 & 0.00 & 1.42 \\
\hline \multirow[t]{2}{*}{ India } & 0.00 & 0.30 & 0.00 & 0.17 \\
\hline & 0.00 & 2.62 & 0.00 & 2.62 \\
\hline \multirow[t]{2}{*}{ Israel } & 1.59 & 0.84 & 0.00 & 1.01 \\
\hline & 8.12 & 7.46 & 0.00 & 15.58 \\
\hline \multirow[t]{2}{*}{ Italy } & 0.42 & 3.50 & 1.73 & 2.31 \\
\hline & 2.15 & 30.95 & 2.47 & 35.57 \\
\hline \multirow[t]{2}{*}{ Japan } & 0.29 & 1.21 & 0.00 & 0.79 \\
\hline & 1.49 & 10.74 & 0.00 & 12.23 \\
\hline \multirow[t]{2}{*}{ Latvia } & 0.00 & 0.13 & 0.00 & 0.07 \\
\hline & 0.00 & 1.11 & 0.00 & 1.11 \\
\hline \multirow[t]{2}{*}{ Luxembourg } & 0.00 & 0.10 & 0.00 & 0.06 \\
\hline & 0.00 & 0.92 & 0.00 & 0.92 \\
\hline \multirow[t]{2}{*}{ Mexico } & 0.00 & 0.19 & 0.00 & 0.11 \\
\hline & 0.00 & 1.69 & 0.00 & 1.69 \\
\hline
\end{tabular}




\begin{tabular}{|c|c|c|c|c|}
\hline Netherlands & 3.15 & 4.68 & 8.21 & 4.50 \\
\hline & 16.12 & 41.36 & 11.75 & 69.23 \\
\hline \multirow[t]{2}{*}{ New Zealand } & 0.16 & 1.19 & 0.00 & 0.74 \\
\hline & 0.80 & 10.54 & 0.00 & 11.34 \\
\hline \multirow[t]{2}{*}{ Norway } & 0.58 & 0.68 & 7.05 & 1.24 \\
\hline & 2.94 & 6.00 & 10.09 & 19.03 \\
\hline \multirow[t]{2}{*}{ Portugal } & 0.00 & 0.45 & 0.00 & 0.26 \\
\hline & 0.00 & 4.01 & 0.00 & 4.01 \\
\hline \multirow[t]{2}{*}{ Russia } & 0.00 & 0.14 & 0.00 & 0.08 \\
\hline & 0.00 & 1.28 & 0.00 & 1.28 \\
\hline \multirow[t]{2}{*}{ Singapore } & 0.54 & 0.80 & 0.00 & 0.64 \\
\hline & 2.73 & 7.06 & 0.00 & 9.79 \\
\hline \multirow[t]{2}{*}{ South Korea } & 0.09 & 0.18 & 2.96 & 0.41 \\
\hline & 0.46 & 1.59 & 4.23 & 6.28 \\
\hline \multirow[t]{2}{*}{ Spain } & 2.87 & 5.88 & 2.28 & 4.55 \\
\hline & 14.64 & 52.05 & 3.26 & 69.95 \\
\hline \multirow[t]{2}{*}{ Sweden } & 0.76 & 1.25 & 0.00 & 0.97 \\
\hline & 3.89 & 11.06 & 0.00 & 14.95 \\
\hline \multirow[t]{2}{*}{ Switzerland } & 5.36 & 2.24 & 17.86 & 4.73 \\
\hline & 27.39 & 19.85 & 25.55 & 72.79 \\
\hline \multirow[t]{2}{*}{ Taiwan } & 0.00 & 0.25 & 0.00 & 0.14 \\
\hline & 0.00 & 2.18 & 0.00 & 2.18 \\
\hline \multirow[t]{2}{*}{ Turkey } & 0.32 & 0.09 & 0.00 & 0.16 \\
\hline & 1.61 & 0.81 & 0.00 & 2.42 \\
\hline \multirow[t]{2}{*}{ UK } & 5.79 & 8.80 & 10.61 & 7.97 \\
\hline & 29.60 & 77.89 & 15.18 & 122.68 \\
\hline \multirow[t]{2}{*}{ US } & 62.23 & 37.84 & 29.10 & 45.22 \\
\hline & 319.39 & 334.79 & 41.64 & 695.82 \\
\hline \multirow[t]{2}{*}{ UAE } & 0.00 & 0.14 & 0.00 & 0.08 \\
\hline & 0.00 & 1.27 & 0.00 & 1.27 \\
\hline \multirow[t]{2}{*}{ Uruguay } & 0.00 & 0.00 & 1.28 & 0.12 \\
\hline & 0.00 & 0.00 & 1.83 & 1.83 \\
\hline \multirow[t]{2}{*}{ Total } & 100.00 & 100.00 & 100.00 & 100.00 \\
\hline & 510.90 & 884.70 & 143.07 & 1538.68 \\
\hline
\end{tabular}

Table 14: Countries' shares and scores, all countries, pooled data from 1998 to 2018 for the AER, from 1999 to 2018 for EE and from 2011 to 2018 for the JEEA. 


\begin{tabular}{|c|c|c|c|c|c|}
\hline & \multicolumn{5}{|c|}{ Shares } \\
\hline & \multicolumn{5}{|c|}{ Scores } \\
\hline & 1999-2003 & 2004-2008 & 2009-2013 & 2014-2018 & 1999-2018 \\
\hline \multirow[t]{2}{*}{ Argentinia } & 0.00 & 0.00 & 0.00 & 0.66 & 0.19 \\
\hline & 0.00 & 0.00 & 0.00 & 2.73 & 2.73 \\
\hline \multirow[t]{2}{*}{ Australia } & 0.67 & 1.41 & 3.44 & 5.09 & 3.28 \\
\hline & 0.71 & 3.94 & 20.12 & 21.23 & 46.00 \\
\hline \multirow[t]{2}{*}{ Austria } & 0.63 & 0.12 & 6.79 & 3.99 & 4.09 \\
\hline & 0.67 & 0.34 & 39.71 & 16.63 & 57.34 \\
\hline \multirow[t]{2}{*}{ Azerbaijan } & 0.00 & 0.00 & 0.00 & 0.31 & 0.09 \\
\hline & 0.00 & 0.00 & 0.00 & 1.29 & 1.29 \\
\hline \multirow[t]{2}{*}{ Belgium } & 0.00 & 0.00 & 0.00 & 0.14 & 0.04 \\
\hline & 0.00 & 0.00 & 0.00 & 0.60 & 0.60 \\
\hline \multirow[t]{2}{*}{ Canada } & 1.58 & 0.88 & 2.78 & 2.85 & 2.32 \\
\hline & 1.68 & 2.46 & 16.23 & 11.89 & 32.58 \\
\hline \multirow[t]{2}{*}{ China } & 1.22 & 1.06 & 0.38 & 3.94 & 1.63 \\
\hline & 1.29 & 2.95 & 2.23 & 16.42 & 22.90 \\
\hline \multirow[t]{2}{*}{ Colombia } & 0.00 & 0.00 & 0.11 & 0.46 & 0.18 \\
\hline & 0.00 & 0.00 & 0.64 & 1.90 & 2.54 \\
\hline \multirow[t]{2}{*}{ Czech Republic } & 0.00 & 0.59 & 0.00 & 0.26 & 0.19 \\
\hline & 0.00 & 1.66 & 0.00 & 1.07 & 2.73 \\
\hline \multirow[t]{2}{*}{ Denmark } & 0.00 & 0.15 & 0.28 & 1.13 & 0.48 \\
\hline & 0.00 & 0.41 & 1.61 & 4.71 & 6.72 \\
\hline \multirow[t]{2}{*}{ Finland } & 0.26 & 0.00 & 0.00 & 0.20 & 0.08 \\
\hline & 0.28 & 0.00 & 0.00 & 0.85 & 1.13 \\
\hline \multirow[t]{2}{*}{ France } & 3.01 & 0.20 & 2.61 & 2.72 & 2.16 \\
\hline & 3.18 & 0.55 & 15.27 & 11.33 & 30.33 \\
\hline \multirow[t]{2}{*}{ Germany } & 4.78 & 5.53 & 9.56 & 12.63 & 9.22 \\
\hline & 5.06 & 15.43 & 55.91 & 52.66 & 129.38 \\
\hline \multirow[t]{2}{*}{ Guatemala } & 0.00 & 0.00 & 0.00 & 0.34 & 0.10 \\
\hline & 0.00 & 0.00 & 0.00 & 1.42 & 1.42 \\
\hline \multirow[t]{2}{*}{ India } & 0.00 & 0.23 & 0.19 & 0.21 & 0.19 \\
\hline & 0.00 & 0.65 & 1.11 & 0.86 & 2.62 \\
\hline \multirow[t]{2}{*}{ Israel } & 1.07 & 0.78 & 1.79 & 0.44 & 1.18 \\
\hline & 1.13 & 2.18 & 10.44 & 1.82 & 16.58 \\
\hline \multirow[t]{2}{*}{ Italy } & 0.61 & 1.23 & 3.06 & 2.66 & 2.40 \\
\hline & 0.65 & 3.44 & 17.91 & 11.09 & 33.60 \\
\hline \multirow[t]{2}{*}{ Japan } & 0.61 & 1.10 & 0.57 & 1.24 & 0.87 \\
\hline & 0.65 & 3.07 & 3.36 & 5.16 & 12.23 \\
\hline \multirow[t]{2}{*}{ Latvia } & 0.00 & 0.00 & 0.19 & 0.00 & 0.08 \\
\hline & 0.00 & 0.00 & 1.11 & 0.00 & 1.11 \\
\hline \multirow[t]{2}{*}{ Luxembourg } & 0.00 & 0.00 & 0.16 & 0.00 & 0.07 \\
\hline & 0.00 & 0.00 & 0.92 & 0.00 & 0.92 \\
\hline Mexico & 0.00 & 0.00 & 0.15 & 0.20 & 0.12 \\
\hline & 0.00 & 0.00 & 0.85 & 0.83 & 1.69 \\
\hline Netherlands & 2.32 & 4.20 & 3.49 & 5.49 & 4.10 \\
\hline & 2.46 & 11.73 & 20.40 & 22.88 & 57.48 \\
\hline
\end{tabular}




\begin{tabular}{|l|c|c|c|c|c|}
\hline New Zealand & 1.67 & 0.16 & 1.15 & 0.58 & 0.81 \\
\hline & 1.77 & 0.45 & 6.72 & 2.40 & 11.34 \\
\hline Norway & 0.00 & 1.05 & 0.00 & 1.44 & 0.64 \\
\hline & 0.00 & 2.94 & 0.00 & 6.00 & 8.94 \\
\hline Portugal & 0.00 & 0.00 & 0.21 & 0.67 & 0.29 \\
\hline Russia & 0.00 & 0.00 & 1.23 & 2.78 & 4.01 \\
\hline & 0.00 & 0.00 & 0.22 & 0.00 & 0.09 \\
\hline Singapore & 0.00 & 0.00 & 1.28 & 0.00 & 1.28 \\
\hline & 0.00 & 0.00 & 0.37 & 1.83 & 0.70 \\
\hline South Korea & 0.00 & 0.00 & 2.16 & 7.63 & 9.79 \\
\hline & 0.00 & 0.00 & 0.27 & 0.00 & 0.15 \\
\hline Spain & 0.00 & 0.00 & 1.59 & 0.00 & 2.05 \\
\hline & 1.70 & 2.81 & 8.46 & 1.82 & 4.78 \\
\hline Sweden & 1.80 & 7.85 & 49.46 & 7.59 & 67.02 \\
\hline & 1.01 & 1.70 & 0.23 & 1.86 & 1.07 \\
\hline Switzerland & 1.07 & 4.74 & 1.37 & 7.76 & 14.95 \\
\hline & 9.19 & 1.30 & 4.49 & 1.83 & 3.37 \\
\hline Taiwan & 9.72 & 3.64 & 26.24 & 7.64 & 47.24 \\
\hline & 0.00 & 0.48 & 0.00 & 0.20 & 0.16 \\
\hline Turkey & 0.00 & 1.34 & 0.00 & 0.83 & 2.18 \\
\hline & 1.52 & 0.00 & 0.14 & 0.00 & 0.17 \\
\hline UK & 1.61 & 0.00 & 0.81 & 0.00 & 2.42 \\
\hline & 3.07 & 6.53 & 9.23 & 7.69 & 7.77 \\
\hline US & 3.25 & 18.24 & 53.93 & 32.08 & 109.00 \\
\hline & 65.07 & 68.47 & 39.68 & 36.83 & 46.85 \\
\hline UAE & 68.87 & 191.12 & 231.94 & 153.56 & 657.18 \\
\hline & 0.00 & 0.00 & 0.00 & 0.30 & 0.09 \\
\hline Total & 0.00 & 0.00 & 0.00 & 1.27 & 1.27 \\
\hline & $\mathbf{1 0 0 . 0 0}$ & $\mathbf{1 0 0 . 0 0}$ & $\mathbf{1 0 0 . 0 0}$ & $\mathbf{1 0 0 . 0 0}$ & $\mathbf{1 0 0 . 0 0}$ \\
\hline & $\mathbf{1 0 5 . 8 5}$ & $\mathbf{2 7 9 . 1 4}$ & $\mathbf{5 8 4 . 5 4}$ & $\mathbf{4 1 6 . 9 2}$ & $\mathbf{1 4 0 2 . 6 1}$ \\
\hline
\end{tabular}

Table 15: Development of geographical concentration of AER and EE authors for all countries, data pooled over different periods. For each country, the first row reports the country's share and the second row reports the country's score. 


\begin{tabular}{|c|c|c|c|c|c|c|}
\hline Country & I: Score & $\begin{array}{l}\text { II: Pop. (in } \\
\text { 1000) }\end{array}$ & $\begin{array}{c}\text { III: } \\
\frac{I}{I I} * 10^{6}\end{array}$ & IV: Score & $\begin{array}{c}\text { V: Pop. (in } \\
1000)\end{array}$ & $\begin{array}{c}\text { VI: } \\
\frac{I V}{V} * 10^{6}\end{array}$ \\
\hline Period & 1999-2003 & 1999 & & 2004-2008 & 2004 & \\
\hline Argentinia & 0.00 & $36,648.1$ & 0.00 & 0.00 & $38,728.7$ & 0.00 \\
\hline Australia & 0.71 & $18,926.0$ & 0.04 & 3.94 & $20,127.4$ & 0.20 \\
\hline Austria & 0.67 & $7,992.3$ & 0.08 & 0.34 & $8,172.0$ & 0.04 \\
\hline Azerbaijan & 0.00 & $7,982.8$ & 0.00 & 0.00 & $8,306.5$ & 0.00 \\
\hline Belgium & 0.00 & $10,226.4$ & 0.00 & 0.00 & $10,421.1$ & 0.00 \\
\hline Canada & 1.68 & $30,499.2$ & 0.05 & 2.46 & $31,995.0$ & 0.08 \\
\hline China & 1.29 & $1,252,735.0$ & 0.00 & 2.95 & $1,296,075.0$ & 0.00 \\
\hline Colombia & 0.00 & $39,819.3$ & 0.00 & 0.00 & $42,724.2$ & 0.00 \\
\hline Czech Rep. & 0.00 & $10,283.9$ & 0.00 & 1.66 & $10,197.1$ & 0.16 \\
\hline Denmark & 0.00 & $5,321.8$ & 0.00 & 0.41 & $5,404.5$ & 0.08 \\
\hline Finland & 0.28 & $5,165.5$ & 0.05 & 0.00 & $5,228.2$ & 0.00 \\
\hline France & 3.18 & $60,496.7$ & 0.05 & 0.55 & $62,704.9$ & 0.01 \\
\hline Germany & 5.06 & $82,100.2$ & 0.06 & 15.43 & $82,516.3$ & 0.19 \\
\hline Guatemala & 0.00 & $11,387.2$ & 0.00 & 0.00 & $12,796.9$ & 0.00 \\
\hline India & 0.00 & $1,034,539.2$ & 0.00 & 0.65 & $1,126,135.8$ & 0.00 \\
\hline Israel & 1.13 & $6,125.0$ & 0.19 & 2.18 & $6,809.0$ & 0.32 \\
\hline Italy & 0.65 & $56,916.3$ & 0.01 & 3.44 & $57,685.3$ & 0.06 \\
\hline Japan & 0.65 & $126,631.0$ & 0.01 & 3.07 & $127,761.0$ & 0.02 \\
\hline Latvia & 0.00 & $2,390.5$ & 0.00 & 0.00 & $2,263.1$ & 0.00 \\
\hline Luxembourg & 0.00 & 430.5 & 0.00 & 0.00 & 458.1 & 0.00 \\
\hline Mexico & 0.00 & $100,300.6$ & 0.00 & 0.00 & $106,995.6$ & 0.00 \\
\hline Netherlands & 2.46 & $15,812.1$ & 0.16 & 11.73 & $16,281.8$ & 0.72 \\
\hline New Zealand & 1.77 & $3,835.1$ & 0.46 & 0.45 & $4,087.5$ & 0.11 \\
\hline Norway & 0.00 & $4,461.9$ & 0.00 & 2.94 & $4,591.9$ & 0.64 \\
\hline Portugal & 0.00 & $10,217.8$ & 0.00 & 0.00 & $10,483.9$ & 0.00 \\
\hline Russia & 0.00 & $147,214.4$ & 0.00 & 0.00 & $144,067.1$ & 0.00 \\
\hline Singapore & 0.00 & $3,958.7$ & 0.00 & 0.00 & $4,166.7$ & 0.00 \\
\hline South Korea & 0.00 & $46,616.7$ & 0.00 & 0.00 & $48,082.5$ & 0.00 \\
\hline Spain & 1.80 & $40,386.9$ & 0.04 & 7.85 & $42,921.9$ & 0.18 \\
\hline Sweden & 1.07 & $8,857.9$ & 0.12 & 4.74 & $8,993.5$ & 0.53 \\
\hline Switzerland & 9.72 & $7,144.9$ & 1.36 & 3.64 & $7,389.6$ & 0.49 \\
\hline Taiwan & 0.00 & $21,712.0$ & 0.00 & 1.34 & $22,462.0$ & 0.06 \\
\hline Turkey & 1.61 & $62,287.3$ & 0.03 & 0.00 & $67,007.9$ & 0.00 \\
\hline UK & 3.25 & $58,682.5$ & 0.06 & 18.24 & $59,987.9$ & 0.30 \\
\hline US & 68.87 & $279,040.0$ & 0.25 & 191.12 & $292,805.3$ & 0.65 \\
\hline UAE & 0.00 & $2,988.2$ & 0.00 & 0.00 & $4,087.9$ & 0.00 \\
\hline Total & 105.85 & & & 279.14 & & \\
\hline
\end{tabular}

Table 16: Scores for the geographical concentration of AER and EE authors per one million inhabitants. Data pooled for periods 1999-2003 and 2004-2008. 


\begin{tabular}{|c|c|c|c|c|c|c|}
\hline Country & I: Score & $\begin{array}{c}\text { II: Pop. (in } \\
\text { 1000) }\end{array}$ & $\begin{array}{c}\text { III: } \\
\frac{I}{I I} * 10^{6}\end{array}$ & IV: Score & $\begin{array}{l}\text { V: Pop. (in } \\
\text { 1000) }\end{array}$ & $\begin{array}{c}\text { VI: } \\
\frac{I V}{V} * 10^{6}\end{array}$ \\
\hline Period & 2009-2013 & 2009 & & 2014-2018 & 2014 & \\
\hline Argentinia & 0.00 & $40,799.4$ & 0.00 & 2.73 & $42,981.5$ & 0.06 \\
\hline Australia & 20.12 & $21,691.7$ & 0.93 & 21.23 & $23,475.7$ & 0.90 \\
\hline Austria & 39.71 & $8,343.3$ & 4.76 & 16.63 & $8,546.4$ & 1.95 \\
\hline Azerbaijan & 0.00 & $8,947.2$ & 0.00 & 1.29 & $9,535.1$ & 0.14 \\
\hline Belgium & 0.00 & $10,796.5$ & 0.00 & 0.60 & $11,209.1$ & 0.05 \\
\hline Canada & 16.23 & $33,628.6$ & 0.48 & 11.89 & $35,535.3$ & 0.33 \\
\hline China & 2.23 & $1,331,260.0$ & 0.00 & 16.42 & $1,364,270.0$ & 0.01 \\
\hline Colombia & 0.64 & $45,416.2$ & 0.01 & 1.90 & $47,791.9$ & 0.04 \\
\hline Czech Rep. & 0.00 & $10,443.9$ & 0.00 & 1.07 & $10,525.3$ & 0.10 \\
\hline Denmark & 1.61 & $5,523.1$ & 0.29 & 4.71 & $5,643.5$ & 0.83 \\
\hline Finland & 0.00 & $5,338.9$ & 0.00 & 0.85 & $5,461.5$ & 0.16 \\
\hline France & 15.27 & $64,707.0$ & 0.24 & 11.33 & $66,316.1$ & 0.17 \\
\hline Germany & 55.91 & $81,902.3$ & 0.68 & 52.66 & $80,982.5$ & 0.65 \\
\hline Guatemala & 0.00 & $14,316.12$ & 0.00 & 1.42 & $15,923.6$ & 0.09 \\
\hline India & 1.11 & $1,214,270.1$ & 0.00 & 0.86 & $1,293,859.3$ & 0.00 \\
\hline Israel & 10.44 & $7,485.6$ & 1.39 & 1.82 & $8,215.7$ & 0.22 \\
\hline Italy & 17.91 & $59,095.4$ & 0.30 & 11.09 & $60,789.1$ & 0.18 \\
\hline Japan & 3.36 & $128,047.0$ & 0.03 & 5.16 & $127,276.0$ & 0.04 \\
\hline Latvia & 1.11 & $2,141.7$ & 0.52 & 0.00 & $1,993.8$ & 0.00 \\
\hline Luxembourg & 0.92 & 497.8 & 1.85 & 0.00 & 556.3 & 0.00 \\
\hline Mexico & 0.85 & $115,505.2$ & 0.01 & 0.83 & $124,221.6$ & 0.01 \\
\hline Netherlands & 20.40 & $16,530.4$ & 1.23 & 22.88 & $16,865.0$ & 1.36 \\
\hline New Zealand & 6.72 & $4,302.6$ & 1.56 & 2.40 & $4,509.7$ & 0.53 \\
\hline Norway & 0.00 & $4,828.7$ & 0.00 & 6.00 & $5,137.2$ & 1.17 \\
\hline Portugal & 1.23 & $10,568.2$ & 0.12 & 2.78 & $10,401.1$ & 0.27 \\
\hline Russia & 1.28 & $142,785.3$ & 0.01 & 0.00 & $143,819.7$ & 0.00 \\
\hline Singapore & 2.16 & $4,987.6$ & 0.43 & 7.63 & $5,469.7$ & 1.40 \\
\hline South Korea & 1.59 & $49,307.8$ & 0.03 & 0.00 & $50,746.7$ & 0.00 \\
\hline Spain & 49.46 & $46,362.9$ & 1.07 & 7.59 & $46,480.9$ & 0.16 \\
\hline Sweden & 1.37 & $9,298.5$ & 0.15 & 7.76 & $9,696.1$ & 0.80 \\
\hline Switzerland & 26.24 & $7,743.8$ & 3.39 & 7.64 & $8,188.7$ & 0.93 \\
\hline Taiwan & 0.00 & $23,017.0$ & 0.00 & 0.83 & $23,414.0$ & 0.04 \\
\hline Turkey & 0.81 & $71,339.2$ & 0.01 & 0.00 & $77,030.7$ & 0.00 \\
\hline UK & 53.93 & $62,276.3$ & 0.87 & 32.08 & $64,613.2$ & 0.50 \\
\hline US & 231.94 & $306,771.5$ & 0.76 & 153.56 & $318,386.4$ & 0.48 \\
\hline UAE & 0.00 & $7,666.4$ & 0.00 & 1.27 & $9,070.9$ & 0.14 \\
\hline Total & 584.54 & & & 416.92 & & \\
\hline
\end{tabular}

Table 17: Scores for the geographical concentration of AER and EE authors per one million inhabitants. Data pooled for periods 2009-2013 and 2014-2018. 

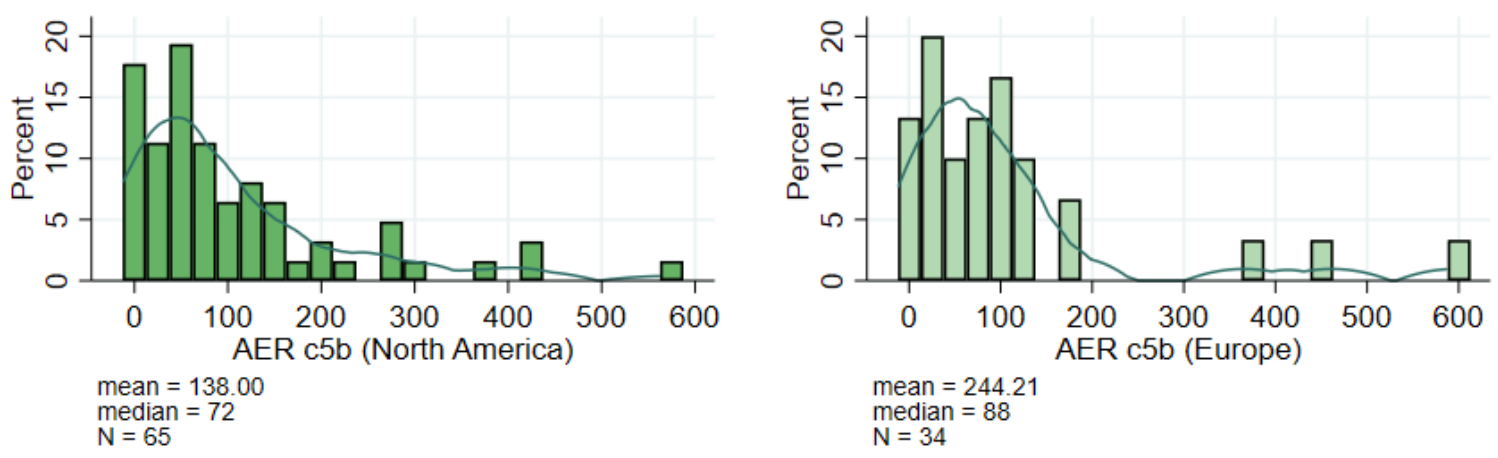

Figure 3: Distribution of citations received 5 years prior publication, for AER authors and experiments conducted in North America or Europe.
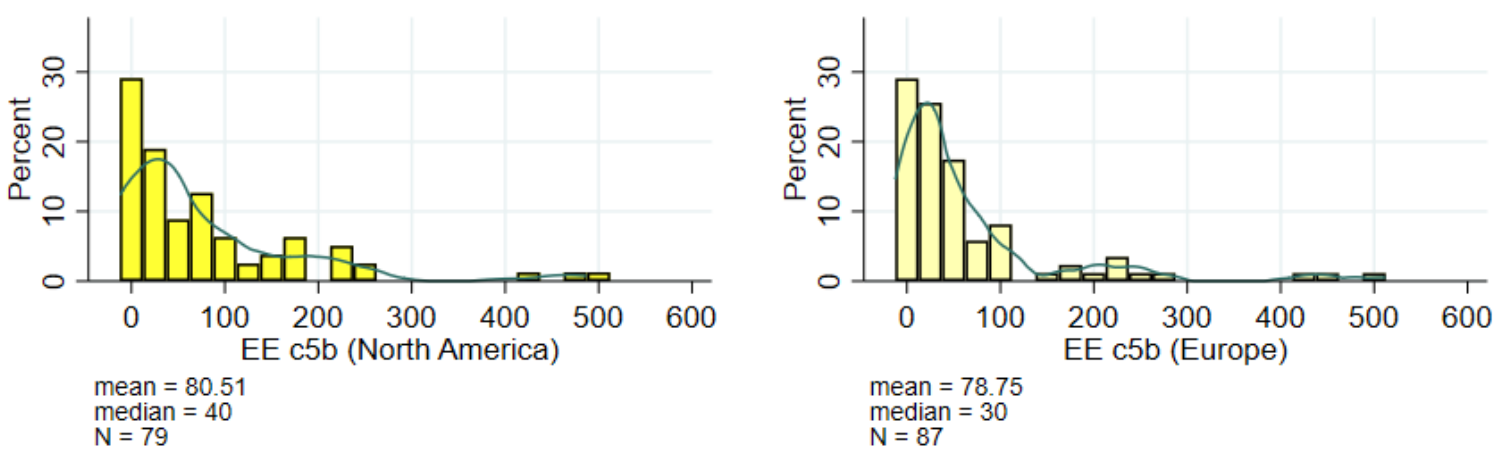

Figure 4: Distribution of citations received 5 years prior publication, for EE authors and experiments conducted in North America or Europe. 


\begin{tabular}{|c|c|c|c|c|c|c|}
\hline & $\begin{array}{l}\text { (1) } \\
\text { c5 }\end{array}$ & $\begin{array}{l}\text { (2) } \\
\text { c5 }\end{array}$ & $\begin{array}{l}\text { (3) } \\
\text { c5 }\end{array}$ & $\begin{array}{l}\text { (4) } \\
\text { c10 }\end{array}$ & $\begin{array}{l}\text { (5) } \\
\text { c10 }\end{array}$ & $\begin{array}{l}\text { (6) } \\
\text { c10 }\end{array}$ \\
\hline Constant & $\begin{array}{l}15.77^{* * *} \\
(7.94)\end{array}$ & $\begin{array}{c}22.50 \\
(17.60)\end{array}$ & $\begin{array}{c}25.09 \\
(19.79)\end{array}$ & $\begin{array}{l}115.74^{* * * *} \\
(32.85)\end{array}$ & $\begin{array}{l}156.46^{* * *} \\
(62.47)\end{array}$ & $\begin{array}{l}167.31^{* *} \\
(71.46)\end{array}$ \\
\hline North America & $\begin{array}{l}-5.06 \\
(4.39)\end{array}$ & $\begin{array}{c}-15.52^{* *} \\
(7.54)\end{array}$ & $\begin{array}{c}-17.02^{* *} \\
(8.07)\end{array}$ & $\begin{array}{l}-24.17 \\
(18.69)\end{array}$ & $\begin{array}{c}-59.56^{* *} \\
(27.33)\end{array}$ & $\begin{array}{l}-76.03^{* *} \\
(28.99)\end{array}$ \\
\hline \multicolumn{7}{|l|}{$\begin{array}{l}\text { Experiment } \\
\text { Quality }\end{array}$} \\
\hline $\begin{array}{l}\text { P1 } \\
\text { (total nr. of part.) }\end{array}$ & & $\begin{array}{l}-0.01 \\
(0.02)\end{array}$ & & & $\begin{array}{c}0.02 \\
(0.08)\end{array}$ & \\
\hline $\begin{array}{l}\mathrm{P} 2 \\
\text { (part. per treatm.) }\end{array}$ & & & $\begin{array}{l}-0.03 \\
(0.03)\end{array}$ & & & $\begin{array}{l}-0.14 \\
(0.11)\end{array}$ \\
\hline $\begin{array}{l}\text { P3 } \\
\text { (treatments) }\end{array}$ & & & $\begin{array}{l}-0.64 \\
(1.53)\end{array}$ & & & $\begin{array}{l}-5.59 \\
(9.34)\end{array}$ \\
\hline $\begin{array}{l}\mathrm{P} 4 \\
\text { (incentives) }\end{array}$ & & $\begin{array}{c}-1.21 \\
(15.10)\end{array}$ & $\begin{array}{c}-1.42 \\
(15.60)\end{array}$ & & $\begin{array}{c}10.56 \\
(45.03)\end{array}$ & $\begin{array}{c}7.85 \\
(47.42)\end{array}$ \\
\hline \multicolumn{7}{|l|}{ Paper Quality } \\
\hline $\begin{array}{l}\text { P5 } \\
\text { (pages) }\end{array}$ & $\begin{array}{l}-0.39 \\
(0.28)\end{array}$ & $\begin{array}{l}-0.25 \\
(0.49)\end{array}$ & $\begin{array}{l}-0.16 \\
(0.51)\end{array}$ & $\begin{array}{l}-2.00 \\
(1.31)\end{array}$ & $\begin{array}{l}-0.06 \\
(2.45)\end{array}$ & $\begin{array}{c}1.54 \\
(3.11)\end{array}$ \\
\hline $\begin{array}{l}\text { P6 } \\
\text { (references) }\end{array}$ & $\begin{array}{c}0.65^{* * * *} \\
(0.17)\end{array}$ & $\begin{array}{l}0.54^{*} \\
(0.27)\end{array}$ & $\begin{array}{l}0.52^{*} \\
(0.28)\end{array}$ & $\begin{array}{c}0.67 \\
(0.91)\end{array}$ & $\begin{array}{l}-2.00 \\
(1.38)\end{array}$ & $\begin{array}{l}-1.94 \\
(1.78)\end{array}$ \\
\hline $\begin{array}{l}\mathrm{P} 7 \\
\text { (reputation) }\end{array}$ & $\begin{array}{l}0.02^{* *} \\
(0.01)\end{array}$ & $\begin{array}{c}0.02 \\
(0.01)\end{array}$ & $\begin{array}{c}0.02 \\
(0.01)\end{array}$ & $\begin{array}{c}0.03 \\
(0.09)\end{array}$ & $\begin{array}{l}-0.03 \\
(0.24)\end{array}$ & $\begin{array}{c}0.04 \\
(0.30)\end{array}$ \\
\hline Papers\&Proceed. & $\begin{array}{l}-12.46 \\
(8.22) \\
\end{array}$ & $\begin{array}{l}-9.28 \\
(17.66)\end{array}$ & $\begin{array}{l}-5.90 \\
(19.76)\end{array}$ & $\begin{array}{c}-69.30^{* *} \\
(29.80)\end{array}$ & $\begin{array}{l}-37.83 \\
(61.74)\end{array}$ & $\begin{array}{l}-15.80 \\
(68.05)\end{array}$ \\
\hline$N$ & 118 & 61 & 59 & 70 & 26 & 25 \\
\hline Pseudo $\mathrm{R}^{2}$ & 0.03 & 0.02 & 0.02 & 0.01 & 0.02 & 0.03 \\
\hline
\end{tabular}




\begin{tabular}{|c|c|c|c|c|c|c|}
\hline & $\begin{array}{l}(1) \\
\text { c5 }\end{array}$ & $\begin{array}{l}(2) \\
\text { c5 }\end{array}$ & $\begin{array}{l}(3) \\
\text { c5 }\end{array}$ & $\begin{array}{l}(4) \\
\text { c10 }\end{array}$ & $\begin{array}{l}(5) \\
\text { c10 }\end{array}$ & $\begin{array}{l}(6) \\
\text { c10 }\end{array}$ \\
\hline Constant & $\begin{array}{l}8.30^{* * * *} \\
(2.60)\end{array}$ & $\begin{array}{l}7.20^{* *} \\
(3.32)\end{array}$ & $\begin{array}{l}6.34^{*} \\
(3.70)\end{array}$ & $\begin{array}{l}30.81^{\text {** }} \\
(12.45)\end{array}$ & $\begin{array}{c}14.74 \\
(16.59)\end{array}$ & $\begin{array}{c}-1.75 \\
(17.28)\end{array}$ \\
\hline North America & $\begin{array}{l}-2.71^{*} \\
(1.50)\end{array}$ & $\begin{array}{l}-2.91^{*} \\
(1.61)\end{array}$ & $\begin{array}{l}-2.73^{*} \\
(1.60)\end{array}$ & $\begin{array}{r}-11.25^{*} \\
(6.29)\end{array}$ & $\begin{array}{l}-10.23 \\
(7.88)\end{array}$ & $\begin{array}{r}-10.78 \\
(7.34)\end{array}$ \\
\hline \multicolumn{7}{|l|}{$\begin{array}{l}\text { Experiment } \\
\text { Quality }\end{array}$} \\
\hline $\begin{array}{l}\text { P1 } \\
\text { (total nr. of part.) }\end{array}$ & & $\begin{array}{c}0.00 \\
(0.01)\end{array}$ & & & $\begin{array}{c}0.07 \\
(0.04)\end{array}$ & \\
\hline $\begin{array}{l}\mathrm{P} 2 \\
\text { (part. per treatm.) }\end{array}$ & & & $\begin{array}{c}0.00 \\
(0.02)\end{array}$ & & & $\begin{array}{c}0.07 \\
(0.15)\end{array}$ \\
\hline $\begin{array}{l}\text { P3 } \\
\text { (treatments) }\end{array}$ & & & $\begin{array}{c}0.51 \\
(0.37)\end{array}$ & & & $\begin{array}{l}6.69^{* * *} \\
(2.15)\end{array}$ \\
\hline $\begin{array}{l}\mathrm{P} 4 \\
\text { (incentives) }\end{array}$ & & $\begin{array}{c}4.35 \\
(4.42)\end{array}$ & $\begin{array}{c}3.04 \\
(4.50)\end{array}$ & & $\begin{array}{l}22.95 \\
(24.64)\end{array}$ & $\begin{array}{c}25.08 \\
(23.11)\end{array}$ \\
\hline \multicolumn{7}{|l|}{ Paper Quality } \\
\hline $\begin{array}{l}\text { P5 } \\
\text { (pages) }\end{array}$ & $\begin{array}{c}-0.44^{* * * *} \\
(0.13)\end{array}$ & $\begin{array}{l}-0.44^{* * *} \\
(0.13)\end{array}$ & $\begin{array}{c}-0.45^{* * *} \\
(0.13)\end{array}$ & $\begin{array}{l}-1.22^{* *} \\
(0.59)\end{array}$ & $\begin{array}{l}-1.33^{*} \\
(0.67)\end{array}$ & $\begin{array}{l}-1.09^{*} \\
(0.63)\end{array}$ \\
\hline $\begin{array}{l}\text { P6 } \\
\text { (references) }\end{array}$ & $\begin{array}{c}0.27^{* * *} \\
(0.06)\end{array}$ & $\begin{array}{l}0.19^{* * *} \\
(0.07)\end{array}$ & $\begin{array}{l}0.20^{* * *} \\
(0.07)\end{array}$ & $\begin{array}{l}0.56^{* *} \\
(0.28)\end{array}$ & $\begin{array}{c}0.55 \\
(0.34)\end{array}$ & $\begin{array}{c}0.50 \\
(0.32)\end{array}$ \\
\hline $\begin{array}{l}\text { P7 } \\
\text { (reputation) }\end{array}$ & $\begin{array}{l}0.01^{* *} \\
(0.01)\end{array}$ & $\begin{array}{l}0.03^{* * *} \\
(0.01)\end{array}$ & $\begin{array}{l}0.03^{* * *} \\
(0.01)\end{array}$ & $\begin{array}{c}0.03 \\
(0.03)\end{array}$ & $\begin{array}{c}0.08 \\
(0.06)\end{array}$ & $\begin{array}{c}0.04 \\
(0.06)\end{array}$ \\
\hline $\begin{array}{l}N \\
\text { Pseudo } \mathrm{R}^{2}\end{array}$ & $\begin{array}{l}201 \\
0.02\end{array}$ & $\begin{array}{c}138 \\
0.03\end{array}$ & $\begin{array}{l}138 \\
0.03\end{array}$ & $\begin{array}{c}84 \\
0.01\end{array}$ & $\begin{array}{c}50 \\
0.02\end{array}$ & $\begin{array}{c}50 \\
0.04\end{array}$ \\
\hline
\end{tabular}

Table 19: Tobit regressions of $\mathrm{c}(5)$ and $\mathrm{c}(10)$ on place of experimentation, experiments' and papers' quality characteristics. Only EE papers. Standard errors in parentheses: $* p<0.10, * * p<0.05, * * * p<0.01$ 


\section{FULL LIST OF PAPERS IN OUR DATA SET}

\section{American Economic Review}

1. Friedman, D. (1998), Monty Hall's three doors: Construction and deconstruction of a choice anomaly. American Economic Review, 88(4), 933-946.

2. Ho, T. H., Camerer, C., \& Weigelt, K. (1998). Iterated dominance and iterated best response in experimental" p-beauty contests". American Economic Review, 88(4), 947-969.

3. Durham, Y., Hirshleifer, J., \& Smith, V. L. (1998). Do the rich get richer and the poor poorer? Experimental tests of a model of power. American Economic Review, 88(4), 970-983.

4. Rich, C. S., \& Friedman, D. (1998). The matching market institution: A laboratory investigation. American Economic Review, 88(5), 1311-1322.

5. Blume, A., DeJong, D. V., Kim, Y. G., \& Sprinkle, G. B. (1998). Experimental evidence on the evolution of meaning of messages in sender-receiver games. American Economic Review, 88(5), 1323-1340.

6. Corns, A., \& Schotter, A. (1999). Can affirmative action be cost effective? An experimental examination of price-preference auctions. American Economic Review, 89(1), 291-305.

7. Camerer, C., \& Lovallo, D. (1999). Overconfidence and excess entry: An experimental approach. American Economic Review, 89(1), 306-318.

8. Bohnet, I., \& Frey, B. S. (1999). Social distance and other-regarding behavior in dictator games: Comment. American Economic Review, 89(1), 335-339.

9. Schubert, R., Brown, M., Gysler, M., \& Brachinger, H. W. (1999). Financial decision-making: are women really more risk-averse?. American Economic Review, 89(2), 381-385.

10. Croson, R., \& Buchan, N. (1999). Gender and culture: International experimental evidence from trust games. American Economic Review, 89(2), 386-391.

11. Cummings, R. G., \& Taylor, L. O. (1999). Unbiased value estimates for environmental goods: a cheap talk design for the contingent valuation method. American Economic Review, 89(3), 649-665.

12. Capra, C. M., Goeree, J. K., Gomez, R., \& Holt, C. A. (1999). Anomalous behavior in a traveler's dilemma?. American Economic Review, 89(3), 678-690.

13. Duffy, J., \& Ochs, J. (1999). Emergence of money as a medium of exchange: An experimental study. American Economic Review, 89(4), 847-877.

14. Falkinger, J., Fehr, E., Gächter, S., \& Winter-Ember, R. (2000). A simple mechanism for the efficient provision of public goods: Experimental evidence. American Economic Review, 90(1), 247-264.

15. Gabaix, X., \& Laibson, D. I. (2000). A boundedly rational decision algorithm. American Economic Review, 90(2), 433-438.

16. Fehr, E., \& Gachter, S. (2000). Cooperation and punishment in public goods experiments. American Economic Review, 90(4), 980-994.

17. James, D., \& Isaac, R. M. (2000). Asset markets: How they are affected by tournament incentives for individuals. American Economic Review, 90(4), 9951004.

18. Konow, J. (2000). Fair shares: Accountability and cognitive dissonance in allocation decisions. American economic review, 90(4), 1072-1091.

19. Fehr, E., \& Tyran, J. R. (2001). Does money illusion matter?. American Economic Review, 91(5), 1239-1262. 
20. Deck, C. A. (2001). A test of game-theoretic and behavioral models of play in exchange and insurance environments. American Economic Review, 91(5), 15461555.

21. Goeree, K., \& Offerman, T. (2002). Efficiency in auctions with private and common values: An experimental study. American Economic Review, 92(3), 625643.

22. Houser, D., \& Kurzban, R. (2002). Revisiting kindness and confusion in public goods experiments. American Economic Review, 92(4), 1062-1069.

23. Cherry, T. L., Frykblom, P., \& Shogren, J. F. (2002). Hardnose the dictator. American Economic Review, 92(4), 1218-1221.

24. Holt, C. A., \& Laury, S. K. (2002). Risk aversion and incentive effects. American economic review, 92(5), 1644-1655.

25. Chen, Y., \& Snmez, T. (2002). Improving efficiency of on-campus housing: An experimental study. American Economic Review, 92(5), 1669-1686.

26. Masclet, D., Noussair, C., Tucker, S., \& Villeval, M. C. (2003). Monetary and nonmonetary punishment in the voluntary contributions mechanism. American Economic Review, 93(1), 366-380.

27. Cooper, D. J., \& Kagel, J. H. (2003). Lessons learned: generalizing learning across games. American Economic Review, 93(2), 202-207.

28. Andreoni, J., Castillo, M., \& Petrie, R. (2003). What do bargainers' preferences look like? Experiments with a convex ultimatum game. American Economic Review, 93(3), 672-685.

29. Andreoni, J., Harbaugh, W., \& Vesterlund, L. (2003). The carrot or the stick: Rewards, punishments, and cooperation. American Economic Review, 93(3), 893902.

30. Phillips, O. R., Menkhaus, D. J., \& Coatney, K. T. (2003). Collusive practices in repeated English auctions: Experimental evidence on bidding rings. American Economic Review, 93(3), 965-979.

31. Bohnet, I., \& Huck, S. (2004). Repetition and reputation: Implications for trust and trustworthiness when institutions change. American economic review, 94(2), 362366.

32. Capra, M. C. (2004). Mood-driven behavior in strategic interactions. American Economic Review, 94(2), 367-372.

33. Anderson, L. R., Mellor, J. M., \& Milyo, J. (2004). Social capital and contributions in a public-goods experiment. American Economic Review, 94(2), 373-376.

34. Çelen, B., \& Kariv, S. (2004). Distinguishing informational cascades from herd behavior in the laboratory. American Economic Review, 94(3), 484-498.

35. List, J. A., Berrens, R. P., Bohara, A. K., \& Kerkvliet, J. (2004). Examining the role of social isolation on stated preferences. American Economic Review, 94(3), 741752.

36. Engelmann, D., \& Strobel, M. (2004). Inequality aversion, efficiency, and maximin preferences in simple distribution experiments. American economic review, 94(4), 857-869.

37. Chen, Y., \& Gazzale, R. (2004). When does learning in games generate convergence to Nash equilibria? The role of supermodularity in an experimental setting. American Economic Review, 94(5), 1505-1535.

38. Gneezy, U. (2005). Deception: The role of consequences. American Economic Review, 95(1), 384-394.

39. Cooper, D. J., \& Kagel, J. H. (2005). Are two heads better than one? Team versus individual play in signaling games. American Economic Review, 95(3), 477-509. 
40. Duffy, J., \& Fisher, E. O. N. (2005). Sunspots in the Laboratory. American Economic Review, 95(3), 510-529.

41. Plott, C. R., \& Zeiler, K. (2005). The willingness to pay-willingness to accept gap, the" endowment effect," subject misconceptions, and experimental procedures for eliciting valuations. American Economic Review, 95(3), 530-545.

42. Holt, C. A., \& Laury, S. K. (2005). Risk aversion and incentive effects: New data without order effects. American Economic Review, 95(3), 902-912.

43. Charness, G., \& Levin, D. (2005). When optimal choices feel wrong: A laboratory study of Bayesian updating, complexity, and affect. American Economic Review, 95(4), 1300-1309.

44. Cipriani, M., \& Guarino, A. (2005). Herd behavior in a laboratory financial market. American Economic Review, 95(5), 1427-1443.

45. Bó, P. D. (2005). Cooperation under the shadow of the future: experimental evidence from infinitely repeated games. American economic review, 95(5), 15911604.

46. Dufwenberg, M., Lindqvist, T., \& Moore, E. (2005). Bubbles and experience: An experiment. American Economic Review, 95(5), 1731-1737.

47. Weber, R. A. (2006). Managing growth to achieve efficient coordination in large groups. American Economic Review, 96(1), 114-126.

48. Mobius, M. M., \& Rosenblat, T. S. (2006). Why beauty matters. American Economic Review, 96(1), 222-235.

49. Goette, L., Huffman, D., \& Meier, S. (2006). The impact of group membership on cooperation and norm enforcement: Evidence using random assignment to real social groups. American Economic Review, 96(2), 212-216.

50. Brandts, J., \& Cooper, D. J. (2006). A change would do you good.... An experimental study on how to overcome coordination failure in organizations. American Economic Review, 96(3), 669-693.

51. Bereby-Meyer, Y., \& Roth, A. E. (2006). The speed of learning in noisy games: Partial reinforcement and the sustainability of cooperation. American Economic Review, 96(4), 1029-1042.

52. Gabaix, X., Laibson, D., Moloche, G., \& Weinberg, S. (2006). Costly information acquisition: Experimental analysis of a boundedly rational model. American Economic Review, 96(4), 1043-1068.

53. Falk, A., \& Kosfeld, M. (2006). The hidden costs of control. American Economic Review, 96(5), 1611-1630.

54. Butler, D. J., \& Loomes, G. C. (2007). Imprecision as an account of the preference reversal phenomenon. American Economic Review, 97(1), 277-297.

55. Eliaz, K., \& Schotter, A. (2007). Experimental testing of intrinsic preferences for noninstrumental information. American Economic Review, 97(2), 166-169.

56. Cappelen, A. W., Hole, A. D., Sørensen, E. Ø., \& Tungodden, B. (2007). The pluralism of fairness ideals: An experimental approach. American Economic Review, 97(3), 818-827.

57. Casari, M., Ham, J. C., \& Kagel, J. H. (2007). Selection bias, demographic effects, and ability effects in common value auction experiments. American Economic Review, 97(4), 1278-1304.

58. Filiz-Ozbay, E., \& Ozbay, E. Y. (2007). Auctions with anticipated regret: Theory and experiment. American Economic Review, 97(4), 1407-1418.

59. Healy, P. J. (2007). Group reputations, stereotypes, and cooperation in a repeated labor market. American Economic Review, 97(5), 1751-1773.

60. Fisman, R., Kariv, S., \& Markovits, D. (2007). Individual preferences for giving. American Economic Review, 97(5), 1858-1876. 
61. Choi, S., Fisman, R., Gale, D., \& Kariv, S. (2007). Consistency and heterogeneity of individual behavior under uncertainty. American Economic Review, 97(5), 19211938.

62. Charness, G., Rigotti, L., \& Rustichini, A. (2007). Individual behavior and group membership. American Economic Review, 97(4), 1340-1352.

63. Haruvy, E., Lahav, Y., \& Noussair, C. N. (2007). Traders' expectations in asset markets: experimental evidence. American Economic Review, 97(5), 1901-1920.

64. Post, T., Van den Assem, M. J., Baltussen, G., \& Thaler, R. H. (2008). Deal or no deal? decision making under risk in a large-payoff game show. American Economic Review, 98(1), 38-71.

65. Armel, K. C., \& Rangel, A. (2008). The impact of computation time and experience on decision values. American Economic Review, 98(2), 163-68.

66. Ali, S. N., Goeree, J. K., Kartik, N., \& Palfrey, T. R. (2008). Information aggregation in standing and ad hoc committees. American Economic Review, 98(2), 181-86.

67. Battaglini, M., Morton, R. B., \& Palfrey, T. R. (2008). Information aggregation and strategic abstention in large laboratory elections. American Economic Review, 98(2), 194-200.

68. Fryer Jr, R. G., Levitt, S. D., \& List, J. A. (2008). Exploring the impact of financial incentives on stereotype threat: Evidence from a pilot study. American Economic Review, 98(2), 370-75.

69. Hussam, R. N., Porter, D., \& Smith, V. L. (2008). Thar she blows: Can bubbles be rekindled with experienced subjects?. American Economic Review, 98(3), 924-37.

70. Selten, R., \& Chmura, T. (2008). Stationary concepts for experimental 2x2-games. American Economic Review, 98(3), 938-66.

71. Crawford, V. P., Gneezy, U., \& Rottenstreich, Y. (2008). The power of focal points is limited: Even minute payoff asymmetry may yield large coordination failures. American Economic Review, 98(4), 1443-58.

72. Hargreaves Heap, S. P., \& Zizzo, D. J. (2009). The value of groups. American Economic Review, 99(1), 295-323.

73. Chen, Y., \& Li, S. X. (2009). Group identity and social preferences. American Economic Review, 99(1), 431-57.

74. Hossain, T., \& Morgan, J. (2009). The quest for QWERTY. American Economic Review, 99(2), 435-40.

75. Camera, G., \& Casari, M. (2009). Cooperation among strangers under the shadow of the future. American Economic Review, 99(3), 979-1005.

76. Blume, A., Duffy, J., \& Franco, A. M. (2009). Decentralized organizational learning: an experimental investigation. American Economic Review, 99(4), 11781205.

77. Kosfeld, M., Okada, A., \& Riedl, A. (2009). Institution formation in public goods games. American Economic Review, 99(4), 1335-55.

78. Ivanov, A., Levin, D., \& Peck, J. (2009). Hindsight, foresight, and insight: an experimental study of a small-market investment game with common and private values. American Economic Review, 99(4), 1484-1507.

79. Rabin, M., \& Weizsäcker, G. (2009). Narrow bracketing and dominated choices. American Economic Review, 99(4), 1508-43.

80. Landeo, C. M., \& Spier, K. E. (2009). Naked exclusion: an experimental study of contracts with externalities. American Economic Review, 99(5), 1850-77.

81. Ho, T. H., \& Su, X. (2009). Peer-induced fairness in games. American Economic Review, 99(5), 2022-49. 
82. Sutter, M. (2009). Individual behavior and group membership: Comment. American Economic Review, 99(5), 2247-57.

83. Abbink, K., Brandts, J., Herrmann, B., \& Orzen, H. (2010). Intergroup conflict and intra-group punishment in an experimental contest game. American Economic Review, 100(1), 420-47.

84. Carpenter, J., Matthews, P. H., \& Schirm, J. (2010). Tournaments and office politics: Evidence from a real effort experiment. American Economic Review, 100(1), 504-17.

85. Fischbacher, U., \& Gachter, S. (2010). Social preferences, beliefs, and the dynamics of free riding in public goods experiments. American economic review, 100(1), 541-56.

86. Anderson, S. T., Friedman, D., \& Oprea, R. (2010). Preemption games: Theory and experiment. American Economic Review, 100(4), 1778-1803.

87. Hamman, J. R., Loewenstein, G., \& Weber, R. A. (2010). Self-interest through delegation: An additional rationale for the principal-agent relationship. American Economic Review, 100(4), 1826-46.

88. Calsamiglia, C., Haeringer, G., \& Klijn, F. (2010). Constrained school choice: An experimental study. American Economic Review, 100(4), 1860-74.

89. Feri, F., Irlenbusch, B., \& Sutter, M. (2010). Efficiency gains from team-based coordination-large-scale experimental evidence. American Economic Review, 100(4), 1892-1912.

90. Benjamin, D. J., Choi, J. J., \& Strickland, A. J. (2010). Social identity and preferences. American Economic Review, 100(4), 1913-28.

91. Grosskopf, B., \& Sarin, R. (2010). Is reputation good or bad? An experiment. American Economic Review, 100(5), 2187-2204.

92. Dal Bó, P., Foster, A., \& Putterman, L. (2010). Institutions and behavior: Experimental evidence on the effects of democracy. American Economic Review, 100(5), 2205-29.

93. Cabrales, A., Miniaci, R., Piovesan, M., \& Ponti, G. (2010). Social preferences and strategic uncertainty: an experiment on markets and contracts. American Economic Review, 100(5), 2261-78.

94. Ellman, M., \& Pezanis-Christou, P. (2010). Organizational structure, communication, and group ethics. American Economic Review, 100(5), 2478-91.

95. Dal Bó, P., \& Fréchette, G. R. (2011). The evolution of cooperation in infinitely repeated games: Experimental evidence. American Economic Review, 101(1), 41129.

96. Abeler, J., Falk, A., Goette, L., \& Huffman, D. (2011). Reference points and effort provision. American Economic Review, 101(2), 470-92.

97. Fehr, E., Hart, O., \& Zehnder, C. (2011). Contracts as reference pointsexperimental evidence. American Economic Review, 101(2), 493-525.

98. Dulleck, U., Kerschbamer, R., \& Sutter, M. (2011). The economics of credence goods: An experiment on the role of liability, verifiability, reputation, and competition. American Economic Review, 101(2), 526-55.

99. Huck, S., Seltzer, A. J., \& Wallace, B. (2011). Deferred compensation in multiperiod labor contracts: an experimental test of Lazear's model. American Economic Review, 101(2), 819-43.

100. Kogan, S., Kwasnica, A. M., \& Weber, R. A. (2011). Coordination in the presence of asset markets. American Economic Review, 101(2), 927-47.

101. Brown, M., Flinn, C. J., \& Schotter, A. (2011). Real-time search in the laboratory and the market. American Economic Review, 101(2), 948-74. 
102. Isoni, A., Loomes, G., \& Sugden, R. (2011). The Willingness to Pay-Willingness to Accept Gap, the" Endowment Effect," Subject Misconceptions, and Experimental Procedures for Eliciting Valuations: Comment. American Economic Review, 101(2), 991-1011.

103. Charness, G., \& Dufwenberg, M. (2011). Participation. American Economic Review, 101(4), 1211-37.

104. Caplin, A., Dean, M., \& Martin, D. (2011). Search and satisficing. American Economic Review, 101(7), 2899-2922.

105. Ifcher, J., \& Zarghamee, H. (2011). Happiness and time preference: The effect of positive affect in a random-assignment experiment. American Economic Review, 101(7), 3109-29.

106. Friedman, D., \& Oprea, R. (2012). A continuous dilemma. American Economic Review, 102(1), 337-63.

107. Gill, D., \& Prowse, V. (2012). A structural analysis of disappointment aversion in a real effort competition. American Economic Review, 102(1), 469-503.

108. Fudenberg, D., Rand, D. G., \& Dreber, A. (2012). Slow to anger and fast to forgive: Cooperation in an uncertain world. American Economic Review, 102(2), 720-49.

109. Bartling, B., Fehr, E., \& Schmidt, K. M. (2012). Screening, competition, and job design: Economic origins of good jobs. American Economic Review, 102(2), 83464.

110. Kirchler, M., Huber, J., \& Stöckl, T. (2012). Thar she bursts: Reducing confusion reduces bubbles. American Economic Review, 102(2), 865-83.

111. Charness, G., Cobo-Reyes, R., Jiménez, N., Lacomba, J. A., \& Lagos, F. (2012). The hidden advantage of delegation: Pareto improvements in a gift exchange game. American Economic Review, 102(5), 2358-79.

112. Ambrus, A., \& Greiner, B. (2012). Imperfect public monitoring with costly punishment: An experimental study. American Economic Review, 102(7), 3317-32.

113. Andreoni, J., \& Sprenger, C. (2012). Estimating time preferences from convex budgets. American Economic Review, 102(7), 3333-56.

114. Andreoni, J., \& Sprenger, C. (2012). Risk preferences are not time preferences. American Economic Review, 102(7), 3357-76.

115. Arad, A., \& Rubinstein, A. (2012). The 11-20 money request game: A level-k reasoning study. American Economic Review, 102(7), 3561-73.

116. Brock, J. M., Lange, A., \& Ozbay, E. Y. (2013). Dictating the risk: Experimental evidence on giving in risky environments. American Economic Review, 103(1), 415-37.

117. Gibson, R., Tanner, C., \& Wagner, A. F. (2013). Preferences for truthfulness: Heterogeneity among and within individuals. American Economic Review, 103(1), 532-48.

118. Beshears, J., Choi, J. J., Fuster, A., Laibson, D., \& Madrian, B. C. (2013). What goes up must come down? Experimental evidence on intuitive forecasting. American Economic Review, 103(3), 570-74.

119. Fehr, E., Herz, H., \& Wilkening, T. (2013). The lure of authority: Motivation and incentive effects of power. American Economic Review, 103(4), 1325-59.

120. Petersen, L., \& Winn, A. (2014). Does money illusion matter? Comment. American Economic Review, 104(3), 1047-62.

121. Duffy, J., \& Puzzello, D. (2014). Gift exchange versus monetary exchange: Theory and evidence. American economic review, 104(6), 1735-76.

122. Isoni, A., Poulsen, A., Sugden, R., \& Tsutsui, K. (2014). Efficiency, equality, and labeling: An experimental investigation of focal points in explicit bargaining. American Economic Review, 104(10), 3256-87. 
123. De Clippel, G., Eliaz, K., \& Knight, B. (2014). On the selection of arbitrators. American Economic Review, 104(11), 3434-58.

124. Jackson, M. O., \& Yariv, L. (2014). Present bias and collective dynamic choice in the lab. American Economic Review, 104(12), 4184-4204.

125. Eckel, C. C., \& Füllbrunn, S. C. (2015). Thar she blows? Gender, competition, and bubbles in experimental asset markets. American Economic Review, 105(2), 90620.

126. Magnani, J. (2015). Testing for the disposition effect on optimal stopping decisions. American Economic Review, 105(5), 371-75.

127. Cheung, S. L. (2015). Risk preferences are not time preferences: on the elicitation of time preference under conditions of risk: comment. American Economic Review, 105(7), 2242-60.

128. Miao, B., \& Zhong, S. (2015). Risk preferences are not time preferences: Separating risk and time preference: Comment. American Economic Review, 105(7), 2272-86.

129. Di Tella, R., Perez-Truglia, R., Babino, A., \& Sigman, M. (2015). Conveniently upset: Avoiding altruism by distorting beliefs about others' altruism. American Economic Review, 105(11), 3416-42.

130. Heyes, A., \& List, J. A. (2016). Supply and demand for discrimination: strategic revelation of own characteristics in a trust game. American Economic Review, 106(5), 319-23.

131. Attema, A. E., Bleichrodt, H., Gao, Y., Huang, Z., \& Wakker, P. P. (2016). Measuring discounting without measuring utility. American Economic Review, 106(6), 1476-94.

132. Malmendier, U., \& Schmidt, K. M. (2017). You owe me. American Economic Review, 107(2), 493-526.

133. Babcock, L., Recalde, M. P., \& Vesterlund, L. (2017). Gender differences in the allocation of low-promotability tasks: The role of backlash. American Economic Review, 107(5), 131-35.

134. Ottoni-Wilhelm, M., Vesterlund, L., \& Xie, H. (2017). Why do people give? Testing pure and impure altruism. American Economic Review, 107(11), 3617-33.

135. Gneezy, U., Kajackaite, A., \& Sobel, J. (2018). Lying Aversion and the Size of the Lie. American Economic Review, 108(2), 419-53.

\section{$\underline{\text { Experimental Economics }}$}

136. Hey, J. D., \& Di Cagno, D. (1998). Sequential markets: An experimental investigation of Clower's dual-decision hypothesis. Experimental Economics, 1(1), 63-85.

137. Bornstein, G., \& Yaniv, I. (1998). Individual and group behavior in the ultimatum game: are groups more "rational" players? Experimental Economics, 1(1), 101108.

138. Cubitt, R. P., Starmer, C., \& Sugden, R. (1998). On the validity of the random lottery incentive system. Experimental Economics, 1(2), 115-131.

139. Wilson, B. J. (1998). What collusion? Unilateral market power as a catalyst for countercyclical markups. Experimental Economics, 1(2), 133-145.

140. Isaac, R. M., \& Walker, J. M. (1998). Nash as an organizing principle in the voluntary provision of public goods: Experimental evidence. Experimental economics, 1(3), 191-206. 
141. Bolton, G. E., Brandts, J., \& Ockenfels, A. (1998). Measuring motivations for the reciprocal responses observed in a simple dilemma game. Experimental Economics, 1(3), 207-219.

142. Rapoport, A., Daniel, T. E., \& Seale, D. A. (1998). Reinforcement-based adaptive learning in asymmetric two-person bargaining with incomplete information. Experimental Economics, 1(3), 221-253.

143. Chan, K. S., Mestelman, S., Moir, R., \& Muller, R. A. (1999). Heterogeneity and the voluntary provision of public goods. Experimental Economics, 2(1), 5-30.

144. Herne, K. (1999). The effects of decoy gambles on individual choice. Experimental Economics, 2(1), 31-40.

145. Berninghaus, S. K., Ehrhart, K. M., \& Keser, C. (1999). Continuous-time strategy selection in linear population games. Experimental Economics, 2(1), 41-57.

146. Sherstyuk, K. (1999). Collusion without conspiracy: An experimental study of onesided auctions. Experimental Economics, 2(1), 59-75.

147. Cason, T. N., \& Friedman, D. (1999). Learning in a laboratory market with random supply and demand. Experimental Economics, 2(1), 77-98.

148. Coller, M., \& Williams, M. B. (1999). Eliciting individual discount rates. Experimental Economics, 2(2), 107-127.

149. Van Huyck, J., Rankin, F., \& Battalio, R. (1999). What Does it Take to Eliminate the use of a Strategy Strictly Dominated by a Mixture?. Experimental economics, 2(2), 129-150.

150. Cox, J. C., \& Oaxaca, R. L. (2000). Good news and bad news: Search from unknown wage offer distributions. Experimental Economics, 2(3), 197-225.

151. Brandts, J., \& Charness, G. (2000). Hot vs. cold: Sequential responses and preference stability in experimental games. Experimental Economics, 2(3), 227238.

152. Croson, R. T., \& Marks, M. B. (2000). Step returns in threshold public goods: A meta-and experimental analysis. Experimental Economics, 2(3), 239-259.

153. Hoffman, E., McCabe, K., \& Smith, V. (2000). The impact of exchange context on the activation of equity in ultimatum games. Experimental Economics, 3(1), 5-9.

154. List, J. A., \& Cherry, T. L. (2000). Learning to accept in ultimatum games: Evidence from an experimental design that generates low offers. Experimental Economics, 3(1), 11-29.

155. Isaac, R. M., \& James, D. (2000). Robustness of the incentive compatible combinatorial auction. Experimental Economics, 3(1), 31-53.

156. Cookson, R. (2000). Framing effects in public goods experiments. Experimental Economics, 3(1), 55-79.

157. Ortmann, A., Fitzgerald, J., \& Boeing, C. (2000). Trust, reciprocity, and social history: A re-examination. Experimental Economics, 3(1), 81-100.

158. Eckel, C. C., \& Grossman, P. J. (2000). Volunteers and pseudo-volunteers: The effect of recruitment method in dictator experiments. Experimental Economics, $3(2), 107-120$.

159. Allsopp, L., \& Hey, J. D. (2000). Two experiments to test a model of herd behaviour. Experimental Economics, 3(2), 121-136.

160. Anderhub, V., Güth, W., Müller, W., \& Strobel, M. (2000). An experimental analysis of intertemporal allocation behavior. Experimental Economics, 3(2), 137152.

161. Seale, D. A., \& Rapoport, A. (2000). Elicitation of strategy profiles in large group coordination games. Experimental Economics, 3(2), 153-179.

162. McKelvey, R. D., \& Page, T. (2000). An experimental study of the effect of private information in the Coase theorem. Experimental Economics, 3(3), 187-213. 
163. Bardsley, N. (2000). Control without deception: Individual behaviour in free-riding experiments revisited. Experimental Economics, 3(3), 215-240.

164. Engelmann, D., \& Strobel, M. (2000). The false consensus effect disappears if representative information and monetary incentives are given. Experimental Economics, 3(3), 241-260.

165. Harstad, R. M. (2000). Dominant strategy adoption and bidders' experience with pricing rules. Experimental economics, 3(3), 261-280.

166. Hey, J. D. (2001). Does repetition improve consistency?. Experimental Economics, $4(1), 5-54$.

167. Krahnen, J. P., \& Weber, M. (2001). Marketmaking in the laboratory: Does competition matter?. Experimental Economics, 4(1), 55-85.

168. Noussair, C., Robin, S., \& Ruffieux, B. (2001). Price bubbles in laboratory asset markets with constant fundamental values. Experimental Economics, 4(1), 87-105.

169. Dickinson, D. L. (2001). The carrot vs. the stick in work team motivation. Experimental Economics, 4(1), 107-124.

170. Willinger, M., \& Ziegelmeyer, A. (2001). Strength of the social dilemma in a public goods experiment: an exploration of the error hypothesis. Experimental Economics, 4(2), 131-144.

171. McDaniel, T. M., \& Rutström, E. E. (2001). Decision making costs and problem solving performance. Experimental Economics, 4(2), 145-161.

172. Cox, J. C., Dinkin, S., \& Swarthout, J. T. (2001). Endogenous entry and exit in common value auctions. Experimental Economics, 4(2), 163-181.

173. Buckley, N., Chan, K. S., Chowhan, J., Mestelman, S., \& Shehata, M. (2001). Value orientations, income and displacement effects, and voluntary contributions. Experimental Economics, 4(2), 183-195.

174. Kagel, J. H., \& Wolfe, K. W. (2001). Tests of fairness models based on equity considerations in a three-person ultimatum game. Experimental Economics, 4(3), 203-219.

175. Weber, R. A. (2001). Behavior and learning in the "dirty faces" game. Experimental Economics, 4(3), 229-242.

176. Phillips, O. R., Menkhaus, D. J., \& Krogmeier, J. L. (2001). Laboratory behavior in spot and forward auction markets. Experimental Economics, 4(3), 243-256.

177. Knetsch, J. L., Tang, F. F., \& Thaler, R. H. (2001). The endowment effect and repeated market trials: Is the Vickrey auction demand revealing?. Experimental economics, 4(3), 257-269.

178. Anderhub, V., Gächter, S., \& Königstein, M. (2002). Efficient contracting and fair play in a simple principal-agent experiment. Experimental Economics, 5(1), 5-27.

179. Bornstein, G., \& Gneezy, U. (2002). Price competition between teams. Experimental Economics, 5(1), 29-38.

180. Cooper, D. J., \& Stockman, C. K. (2002). Learning to punish: experimental evidence from a sequential step-level public goods game. Experimental Economics, 5(1), 39-51.

181. Cason, T. N., Saijo, T., \& Yamato, T. (2002). Voluntary participation and spite in public good provision experiments: an international comparison. Experimental Economics, 5(2), 133-153.

182. Archibald, G., \& Wilcox, N. T. (2002). A New Variant of the Winner's Curse in a Coasian Contracting Game. Experimental Economics, 5(2), 155-172.

183. Brewer, P. J., Huang, M., Nelson, B., \& Plott, C. R. (2002). On the behavioral foundations of the law of supply and demand: Human convergence and robot randomness. Experimental economics, 5(3), 179-208. 
184. Swope, K. J. (2002). An experimental investigation of excludable public goods. Experimental Economics, 5(3), 209-222.

185. Clark, J. (2002). House money effects in public good experiments. Experimental Economics, 5(3), 223-231.

186. Roelofs, M. R. (2002). Common value auctions with default: an experimental approach. Experimental Economics, 5(3), 233-252.

187. Zwick, R., \& Rapoport, A. (2002). Tacit coordination in a decentralized market entry game with fixed capacity. Experimental Economics, 5(3), 253-272.

188. Muller, R. A., \& Sadanand, A. (2003). Order of play, forward induction, and presentation effects in two-person games. Experimental Economics, 6(1), 5-25.

189. Anderhub, V., Güth, W., Kamecke, U., \& Normann, H. T. (2003). Capacity choices and price competition in experimental markets. Experimental Economics, 6(1), 2752.

190. Devetag, G. (2003). Coordination and information in critical mass games: an experimental study. Experimental economics, 6(1), 53-73.

191. Brosig, J., Weimann, J., \& Yang, C. L. (2003). The hot versus cold effect in a simple bargaining experiment. Experimental Economics, 6(1), 75-90.

192. Bru, L., Cabrera, S., Capra, C. M., \& Gomez, R. (2003). A common pool resource game with sequential decisions and experimental evidence. Experimental Economics, 6(1), 91-114.

193. Dorsey, R., \& Razzolini, L. (2003). Explaining overbidding in first price auctions using controlled lotteries. Experimental Economics, 6(2), 123-140.

194. Grosskopf, B. (2003). Reinforcement and directional learning in the ultimatum game with responder competition. Experimental Economics, 6(2), 141-158.

195. Sgroi, D. (2003). The right choice at the right time: A herding experiment in endogenous time. Experimental Economics, 6(2), 159-180.

196. Cooper, D. J., Feltovich, N., Roth, A. E., \& Zwick, R. (2003). Relative versus absolute speed of adjustment in strategic environments: responder behavior in ultimatum games. Experimental Economics, 6(2), 181-207.

197. Davis, D. D., Reilly, R. J., \& Wilson, B. J. (2003). Cost structures and Nash play in repeated Cournot games. Experimental Economics, 6(2), 209-226.

198. Palacios-Huerta, I. (2003). Learning to open Monty Hall's doors. Experimental Economics, 6(3), 235-251.

199. Meidinger, C., Rullière, J. L., \& Villeval, M. C. (2003). Does team-based compensation give rise to problems when agents vary in their ability?. Experimental Economics, 6(3), 253-272.

200. Nirel, R., \& Gorfine, M. (2003). Nonparametric Analysis of Longitudinal Binary Data: An Application to the Intergroup Prisoner's Dilemma Game. Experimental Economics, 6(3), 327-341.

201. Weber, R. A., Camerer, C. F., \& Knez, M. (2004). Timing and virtual observability in ultimatum bargaining and "weak link" coordination games. Experimental Economics, 7(1), 25-48.

202. Schmitt, P. M. (2004). On perceptions of fairness: The role of valuations, outside options, and information in ultimatum bargaining games. Experimental Economics, 7(1), 49-73.

203. Stevens, D. E., \& Williams, A. W. (2004). Inefficiency in earnings forecasts: Experimental evidence of reactions to positive vs. negative information. Experimental Economics, 7(1), 75-92.

204. Parkhurst, G. M., Shogren, J. F., \& Bastian, C. (2004). Repetition, communication, and coordination failure. Experimental Economics, 7(2), 141-152. 
205. Levati, M. V., \& Neugebauer, T. (2004). An application of the English clock market mechanism to public goods games. Experimental Economics, 7(2), 153-169.

206. Charness, G., Frechette, G. R., \& Kagel, J. H. (2004). How robust is laboratory gift exchange?. Experimental Economics, 7(2), 189-205.

207. Dale, D. J. (2004). Charitable lottery structure and fund raising: Theory and evidence. Experimental Economics, 7(3), 217-234.

208. Walker, J. M., \& Halloran, M. A. (2004). Rewards and sanctions and the provision of public goods in one-shot settings. Experimental Economics, 7(3), 235-247.

209. Rassenti, S. J., \& Wilson, B. J. (2004). How applicable is the dominant firm model of price leadership?. Experimental Economics, 7(3), 271-288.

210. Selten, R., Abbink, K., \& Cox, R. (2005). Learning direction theory and the winner's curse. Experimental Economics, 8(1), 5-20.

211. Kachelmeier, S. J., \& Towry, K. L. (2005). The limitations of experimental design: A case study involving monetary incentive effects in laboratory markets. Experimental Economics, 8(1), 21-33.

212. Burlando, R. M., \& Guala, F. (2005). Heterogeneous agents in public goods experiments. Experimental Economics, 8(1), 35-54.

213. Slonim, R. L. (2005). Competing against experienced and inexperienced players. Experimental Economics, 8(1), 55-75.

214. Davis, D. D., Millner, E. L., \& Reilly, R. J. (2005). Subsidy schemes and charitable contributions: A closer look. Experimental Economics, 8(2), 85-106.

215. Seale, D. A., Parco, J. E., Stein, W. E., \& Rapoport, A. (2005). Joining a queue or staying out: Effects of information structure and service time on arrival and staying out decisions. Experimental Economics, 8(2), 117-144.

216. Dickinson, D. L. (2005). Bargaining outcomes with double-offer arbitration. Experimental Economics, 8(2), 145-166.

217. kan Holm, H., \& Engseld, P. (2005). Choosing bargaining partners-An experimental study on the impact of information about income, status and gender. Experimental Economics, 8(3), 183-216.

218. Hey, J. D., \& Lee, J. (2005). Do subjects separate (or are they sophisticated)?. Experimental Economics, 8(3), 233-265.

219. Lindqvist, T., \& Stennek, J. (2005). The insiders' dilemma: an experiment on merger formation. Experimental Economics, 8(3), 267-284.

220. Ackert, L. F., Charupat, N., Church, B. K., \& Deaves, R. (2006). An experimental examination of the house money effect in a multi-period setting. Experimental Economics, 9(1), 5-16.

221. Fischer, S., Güth, W., Müller, W., \& Stiehler, A. (2006). From ultimatum to Nash bargaining: Theory and experimental evidence. Experimental Economics, 9(1), 1733.

222. Bosman, R., Hennig-Schmidt, H., \& Van Winden, F. (2006). Exploring group decision making in a power-to-take experiment. Experimental Economics, 9(1), 3551.

223. Eckel, C. C., \& Wilson, R. K. (2006). Internet cautions: Experimental games with internet partners. Experimental Economics, 9(1), 53-66.

224. Abbink, K., \& Hennig-Schmidt, H. (2006). Neutral versus loaded instructions in a bribery experiment. Experimental Economics, 9(2), 103-121.

225. Schotter, A., \& Sopher, B. (2006). Trust and trustworthiness in games: An experimental study of intergenerational advice. Experimental Economics, 9(2), 123145.

226. Murphy, R. O., Rapoport, A., \& Parco, J. E. (2006). The breakdown of cooperation in iterative real-time trust dilemmas. Experimental Economics, 9(2), 147-166. 
227. Ashraf, N., Bohnet, I., \& Piankov, N. (2006). Decomposing trust and trustworthiness. Experimental Economics, 9(3), 193-208.

228. Cox, J. C., \& Hayne, S. C. (2006). Barking up the right tree: Are small groups rational agents?. Experimental Economics, 9(3), 209-222.

229. Anderson, L. R., Mellor, J. M., \& Milyo, J. (2006). Induced heterogeneity in trust experiments. Experimental Economics, 9(3), 223-235.

230. Berninghaus, S. K., Ehrhart, K. M., \& Ott, M. (2006). A network experiment in continuous time: The influence of link costs. Experimental Economics, 9(3), 237251.

231. Cinyabuguma, M., Page, T., \& Putterman, L. (2006). Can second-order punishment deter perverse punishment?. Experimental Economics, 9(3), 265-279.

232. Loewenstein, G., Moore, D. A., \& Weber, R. A. (2006). Misperceiving the value of information in predicting the performance of others. Experimental Economics, 9(3), 281-295.

233. McKinney, C. N., \& Van Huyck, J. B. (2006). Does seeing more deeply into a game increase one's chances of winning?. Experimental economics, 9(3), 297-303.

234. Cadsby, C. B., Maynes, E., \& Trivedi, V. U. (2006). Tax compliance and obedience to authority at home and in the lab: A new experimental approach. Experimental economics, 9(4), 343-359.

235. Bodoff, D., Levecq, H., \& Zhang, H. (2006). EDGAR on the internet: The welfare effects of wider information distribution in an experimental market for risky assets. Experimental Economics, 9(4), 361-381.

236. Andersen, S., Harrison, G. W., Lau, M. I., \& Rutström, E. E. (2006). Elicitation using multiple price list formats. Experimental Economics, 9(4), 383-405.

237. Brandts, J., \& Cooper, D. J. (2006). Observability and overcoming coordination failure in organizations: An experimental study. Experimental Economics, 9(4), 407-423.

238. Yang, C. L., Yue, C. S. J., \& Yu, I. T. (2007). The rise of cooperation in correlated matching prisoners dilemma: An experiment. Experimental Economics, 10(1), 3-20.

239. Bullock, D. S., \& Rutström, E. E. (2007). Policy making and rent-dissipation: An experimental test. Experimental Economics, 10(1), 21-36.

240. Turocy, T. L., Watson, E., \& Battalio, R. C. (2007). Framing the first-price auction. Experimental Economics, 10(1), 37-51.

241. Albert, M., Güth, W., Kirchler, E., \& Maciejovsky, B. (2007). Are we nice (r) to nice (r) people? - an experimental analysis. Experimental Economics, 10(1), 53-69.

242. Friedman, D., Pommerenke, K., Lukose, R., Milam, G., \& Huberman, B. A. (2007). Searching for the sunk cost fallacy. Experimental Economics, 10(1), 79-104.

243. James, D. (2007). Stability of risk preference parameter estimates within the Becker-DeGroot-Marschak procedure. Experimental Economics, 10(2), 123-141.

244. Healy, P. J., Ledyard, J. O., Noussair, C., Thronson, H., Ulrich, P., \& Varsi, G. (2007). Contracting inside an organization: An experimental study. Experimental Economics, 10(2), 143-167.

245. Van Huyck, J. B., Battalio, R. C., \& Rankin, F. W. (2007). Evidence on learning in coordination games. Experimental Economics, 10(3), 205-220.

246. Cabrales, A., Nagel, R., \& Armenter, R. (2007). Equilibrium selection through incomplete information in coordination games: an experimental study. Experimental Economics, 10(3), 221-234.

247. Hess, R. O., Holt, C. A., \& Smith, A. M. (2007). Coordination of strategic responses to security threats: Laboratory evidence. Experimental Economics, 10(3), 235-250. 
248. Cason, T. N., \& Mui, V. L. (2007). Communication and coordination in the laboratory collective resistance game. Experimental Economics, 10(3), 251-267.

249. Brandts, J., Cooper, D. J., \& Fatas, E. (2007). Leadership and overcoming coordination failure with asymmetric costs. Experimental Economics, 10(3), 269284.

250. Hamman, J., Rick, S., \& Weber, R. A. (2007). Solving coordination failure with "all-or-none" group-level incentives. Experimental Economics, 10(3), 285-303.

251. Carare, O., Haruvy, E., \& Prasad, A. (2007). Hierarchical thinking and learning in rank order contests. Experimental Economics, 10(3), 305-316.

252. Eckel, C. C., \& Wilson, R. K. (2007). Social learning in coordination games: does status matter?. Experimental Economics, 10(3), 317-329.

253. Vandegrift, D., Yavas, A., \& Brown, P. M. (2007). Incentive effects and overcrowding in tournaments: An experimental analysis. Experimental Economics, 10(4), 345-368.

254. Poulsen, A. U., \& Tan, J. H. (2007). Information acquisition in the ultimatum game: An experimental study. Experimental Economics, 10(4), 391-409.

255. Kroll, S., Cherry, T. L., \& Shogren, J. F. (2007). The impact of endowment heterogeneity and origin on contributions in best-shot public good games. Experimental Economics, 10(4), 411-428.

256. Harrison, G. W. (2007). House money effects in public good experiments: Comment. Experimental Economics, 10(4), 429-437.

257. Deck, C., Farmer, A., \& Zeng, D. Z. (2007). Amended final-offer arbitration over an uncertain value: A comparison with CA and FOA. Experimental Economics, 10(4), 439-454.

258. Cox, J. C., Sadiraj, K., \& Sadiraj, V. (2008). Implications of trust, fear, and reciprocity for modeling economic behavior. Experimental Economics, 11(1), 1-24.

259. Vyrastekova, J., \& Van Soest, D. (2008). On the (in) effectiveness of rewards in sustaining cooperation. Experimental Economics, 11(1), 53-65.

260. Goswami, G., Grace, M. F., \& Rebello, M. J. (2008). Experimental evidence on coverage choices and contract prices in the market for corporate insurance. Experimental Economics, 11(1), 67-95.

261. Sbriglia, P. (2008). Revealing the depth of reasoning in p-beauty contest games. Experimental Economics, 11(2), 107-121.

262. Bardsley, N. (2008). Dictator game giving: altruism or artefact?. Experimental Economics, 11(2), 122-133.

263. Iyengar, R., \& Schotter, A. (2008). Learning under supervision: an experimental study. Experimental Economics, 11(2), 154-173.

264. Karni, E., Salmon, T., \& Sopher, B. (2008). Individual sense of fairness: an experimental study. Experimental Economics, 11(2), 174-189.

265. Neugebauer, T., \& Perote, J. (2008). Bidding 'as if'risk neutral in experimental first price auctions without information feedback. Experimental Economics, 11(2), 190202.

266. Dasgupta, S., Randazzo, K. A., Sheehan, R. S., \& Williams, K. C. (2008). Coordinated voting in sequential and simultaneous elections: some experimental evidence. Experimental Economics, 11(4), 315-335.

267. Yamamori, T., Kato, K., Kawagoe, T., \& Matsui, A. (2008). Voice matters in a dictator game. Experimental Economics, 11(4), 336-343.

268. Katok, E., \& Kwasnica, A. M. (2008). Time is money: The effect of clock speed on seller's revenue in Dutch auctions. Experimental Economics, 11(4), 344-357.

269. Nikiforakis, N., \& Normann, H. T. (2008). A comparative statics analysis of punishment in public-good experiments. Experimental Economics, 11(4), 358-369. 
270. Kurzban, R., Rigdon, M. L., \& Wilson, B. J. (2008). Incremental approaches to establishing trust. Experimental Economics, 11(4), 370-389.

271. Orzen, H. (2008). Counterintuitive number effects in experimental oligopolies. Experimental Economics, 11(4), 390-401.

272. Grimm, V., Kovarik, J., \& Ponti, G. (2008). Fixed price plus rationing: an experiment. Experimental Economics, 11(4), 402-422.

273. Deck, C. (2009). An experimental analysis of cooperation and productivity in the trust game. Experimental economics, 12(1), 1-11.

274. Bone, J., Hey, J. D., \& Suckling, J. (2009). Do people plan?. Experimental Economics, 12(1), 12-25.

275. Luhan, W. J., Kocher, M. G., \& Sutter, M. (2009). Group polarization in the team dictator game reconsidered. Experimental Economics, 12(1), 26-41.

276. Sherstyuk, K. (2009). A comparison of first price multi-object auctions. Experimental Economics, 12(1), 42-64.

277. Davis, D., Korenok, O., \& Reilly, R. (2009). Re-matching, information and sequencing effects in posted offer markets. Experimental Economics, 12(1), 65-86.

278. Herrmann, B., \& Thöni, C. (2009). Measuring conditional cooperation: a replication study in Russia. Experimental Economics, 12(1), 87-92.

279. Aguiar, F., Brañas-Garza, P., Cobo-Reyes, R., Jimenez, N., \& Miller, L. M. (2009). Are women expected to be more generous?. Experimental Economics, 12(1), 93-98.

280. Harrison, G. W., \& Rutström, E. E. (2009). Expected utility theory and prospect theory: One wedding and a decent funeral. Experimental economics, 12(2), 133158.

281. Chou, E., McConnell, M., Nagel, R., \& Plott, C. R. (2009). The control of game form recognition in experiments: Understanding dominant strategy failures in a simple two person "guessing" game. Experimental Economics, 12(2), 159-179.

282. Hurkens, S., \& Kartik, N. (2009). Would I lie to you? On social preferences and lying aversion. Experimental Economics, 12(2), 180-192.

283. Sausgruber, R. (2009). A note on peer effects between teams. Experimental Economics, 12(2), 193-201.

284. Zhang, P. (2009). Uniform price auctions and fixed price offerings in IPOs: an experimental comparison. Experimental Economics, 12(2), 202-219.

285. Sánchez-Pagés, S., \& Vorsatz, M. (2009). Enjoy the silence: an experiment on truth-telling. Experimental Economics, 12(2), 220-241.

286. Stahl, D. O., \& Haruvy, E. (2009). Testing theories of behavior for extensive-form two-player two-stage games. Experimental economics, 12(2), 242-251.

287. Goerg, S. J., \& Selten, R. (2009). Experimental investigation of stationary concepts in cyclic duopoly games. Experimental Economics, 12(3), 253-271.

288. Carpenter, J., \& Matthews, P. H. (2009). What norms trigger punishment?. Experimental Economics, 12(3), 272-288.

289. Mago, S. D., \& Dechenaux, E. (2009). Price leadership and firm size asymmetry: an experimental analysis. Experimental Economics, 12(3), 289-317.

290. Sutter, M., Bosman, R., Kocher, M. G., \& van Winden, F. (2009). Gender pairing and bargaining - Beware the same sex!. Experimental Economics, 12(3), 318-331.

291. Blavatskyy, P. R., \& Köhler, W. R. (2009). Range effects and lottery pricing. Experimental Economics, 12(3), 332-349.

292. Becker, O., Leitner, J., \& Leopold-Wildburger, U. (2009). Expectation formation and regime switches. Experimental Economics, 12(3), 350-364.

293. Bruner, D. M. (2009). Changing the probability versus changing the reward. Experimental Economics, 12(4), 367-385. 
294. Healy, A. (2009). How effectively do people learn from a variety of different opinions?. Experimental Economics, 12(4), 386-416.

295. Boone, J., Chen, R., Goeree, J. K., \& Polydoro, A. (2009). Risky procurement with an insider bidder. Experimental Economics, 12(4), 417-436.

296. Becker, A., \& Miller, L. M. (2009). Promoting justice by treating people unequally: an experimental study. Experimental Economics, 12(4), 437-449.

297. Hyndman, K., Terracol, A., \& Vaksmann, J. (2009). Learning and sophistication in coordination games. Experimental Economics, 12(4), 450-472.

298. Rydval, O., Ortmann, A., Prokosheva, S., \& Hertwig, R. (2009). How certain is the uncertainty effect?. Experimental Economics, 12(4), 473-487.

299. Barr, A., \& Serra, D. (2009). The effects of externalities and framing on bribery in a petty corruption experiment. Experimental Economics, 12(4), 488-503.

300. Tufano, F. (2010). Are 'true'preferences revealed in repeated markets? An experimental demonstration of context-dependent valuations. Experimental Economics, 13(1), 1-13.

301. Isaac, R. M., Pevnitskaya, S., \& Salmon, T. C. (2010). Do preferences for charitable giving help auctioneers?. Experimental economics, 13(1), 14-44.

302. Davis, D., Korenok, O., \& Reilly, R. (2010). Cooperation without coordination: Signaling, types and tacit collusion in laboratory oligopolies. Experimental economics, 13(1), 45-65.

303. Cox, J. C., Servátka, M., \& Vadovič, R. (2010). Saliency of outside options in the lost wallet game. Experimental Economics, 13(1), 66-74.

304. Ziegelmeyer, A., Koessler, F., Bracht, J., \& Winter, E. (2010). Fragility of information cascades: an experimental study using elicited beliefs. Experimental Economics, 13(2), 121-145.

305. Engle-Warnick, J., \& Turdaliev, N. (2010). An experimental test of Taylor-type rules with inexperienced central bankers. Experimental Economics, 13(2), 146-166.

306. Kagel, J. H., Sung, H., \& Winter, E. (2010). Veto power in committees: an experimental study. Experimental Economics, 13(2), 167-188.

307. Davis, L. R., Joyce, B. P., \& Roelofs, M. R. (2010). My money or yours: house money payment effects. Experimental Economics, 13(2), 189-205.

308. Poulsen, A. U., \& Roos, M. W. (2010). Do people make strategic commitments? Experimental evidence on strategic information avoidance. Experimental Economics, 13(2), 206-225.

309. Coricelli, G., Joffily, M., Montmarquette, C., \& Villeval, M. C. (2010). Cheating, emotions, and rationality: an experiment on tax evasion. Experimental Economics, 13(2), 226-247.

310. Engelmann, D., \& Normann, H. T. (2010). Maximum effort in the minimum-effort game. Experimental Economics, 13(3), 249-259.

311. Bornhorst, F., Ichino, A., Kirchkamp, O., Schlag, K. H., \& Winter, E. (2010). Similarities and differences when building trust: the role of cultures. Experimental Economics, 13(3), 260-283.

312. Cadsby, C. B., Servátka, M., \& Song, F. (2010). Gender and generosity: does degree of anonymity or group gender composition matter?. Experimental economics, 13(3), 299-308.

313. Bellemare, C., Bissonnette, L., \& Kröger, S. (2010). Bounding preference parameters under different assumptions about beliefs: a partial identification approach. Experimental economics, 13(3), 334-345.

314. Chaudhuri, A., \& Paichayontvijit, T. (2010). Recommended play and performance bonuses in the minimum effort coordination game. Experimental Economics, 13(3), 346-363. 
315. Gächter, S., \& Renner, E. (2010). The effects of (incentivized) belief elicitation in public goods experiments. Experimental Economics, 13(3), 364-377.

316. Veiga, H., \& Vorsatz, M. (2010). Information aggregation in experimental asset markets in the presence of a manipulator. Experimental Economics, 13(4), 379-398.

317. Fatas, E., Meléndez-Jiménez, M. A., \& Solaz, H. (2010). An experimental analysis of team production in networks. Experimental Economics, 13(4), 399-411.

318. Blanco, M., Engelmann, D., Koch, A. K., \& Normann, H. T. (2010). Belief elicitation in experiments: is there a hedging problem?. Experimental Economics, 13(4), 412-438.

319. Darai, D., Sacco, D., \& Schmutzler, A. (2010). Competition and innovation: An experimental investigation. Experimental Economics, 13(4), 439-460.

320. Takeuchi, K., Lin, J. C., Chen, Y., \& Finholt, T. A. (2010). Scheduling with package auctions. Experimental economics, 13(4), 476-499.

321. Krawczyk, M., \& Le Lec, F. (2010). 'Give me a chance!'An experiment in social decision under risk. Experimental Economics, 13(4), 500-511.

322. Houser, D., \& Xiao, E. (2011). Classification of natural language messages using a coordination game. Experimental Economics, 14(1), 1-14.

323. Requate, T., \& Waichman, I. (2011). “A profit table or a profit calculator?" A note on the design of Cournot oligopoly experiments. Experimental Economics, 14(1), $36-46$.

324. Kimbrough, E. O. (2011). Learning to respect property by refashioning theft into trade. Experimental economics, 14(1), 84-109.

325. Comerton-Forde, C., \& Putniņš, T. J. (2011). Pricing accuracy, liquidity and trader behavior with closing price manipulation. Experimental economics, 14(1), 110-131.

326. Cabrales, A., Charness, G., \& Villeval, M. C. (2011). Hidden information, bargaining power, and efficiency: an experiment. Experimental Economics, 14(2), 133-159.

327. Iriberri, N., \& Rey-Biel, P. (2011). The role of role uncertainty in modified dictator games. Experimental Economics, 14(2), 160-180.

328. Mittone, L., \& Ploner, M. (2011). Peer pressure, social spillovers, and reciprocity: an experimental analysis. Experimental Economics, 14(2), 203-222.

329. Huber, J., Angerer, M., \& Kirchler, M. (2011). Experimental asset markets with endogenous choice of costly asymmetric information. Experimental Economics, 14(2), 223-240.

330. Cubitt, R. P., Drouvelis, M., \& Gächter, S. (2011). Framing and free riding: emotional responses and punishment in social dilemma games. Experimental Economics, 14(2), 254-272.

331. Gazzale, R. S., \& Khopkar, T. (2011). Remain silent and ye shall suffer: seller exploitation of reticent buyers in an experimental reputation system. Experimental Economics, 14(2), 273-285.

332. Uler, N. (2011). Public goods provision, inequality and taxes. Experimental Economics, 14(3), 287-306.

333. Ackert, L. F., Gillette, A. B., Martinez-Vazquez, J., \& Rider, M. (2011). Are benevolent dictators altruistic in groups? A within-subject design. Experimental Economics, 14(3), 307-321.

334. Otto, P. E., \& Bolle, F. (2011). Matching markets with price bargaining. Experimental Economics, 14(3), 322-348.

335. Ballinger, T. P., Hudson, E., Karkoviata, L., \& Wilcox, N. T. (2011). Saving behavior and cognitive abilities. Experimental Economics, 14(3), 349-374. 
336. Anderson, L. R., DiTraglia, F. J., \& Gerlach, J. R. (2011). Measuring altruism in a public goods experiment: a comparison of US and Czech subjects. Experimental Economics, 14(3), 426-437.

337. Osés-Eraso, N., \& Viladrich-Grau, M. (2011). The sustainability of the commons: giving and receiving. Experimental Economics, 14(4), 458-481.

338. Visser, M. S., \& Roelofs, M. R. (2011). Heterogeneous preferences for altruism: gender and personality, social status, giving and taking. Experimental Economics, 14(4), 490-506.

339. Vieider, F. M. (2011). Separating real incentives and accountability. Experimental Economics, 14(4), 507-518.

340. Janssen, M. A., Anderies, J. M., \& Joshi, S. R. (2011). Coordination and cooperation in asymmetric commons dilemmas. Experimental Economics, 14(4), 547-566.

341. Di Mauro, C., \& Castro, M. F. (2011). Kindness, confusion, or... ambiguity?. Experimental Economics, 14(4), 611-633.

342. Proto, E., Sgroi, D., \& Oswald, A. J. (2012). Are happiness and productivity lower among young people with newly-divorced parents? An experimental and econometric approach. Experimental Economics, 15(1), 1-23.

343. Reuben, E., \& Suetens, S. (2012). Revisiting strategic versus non-strategic cooperation. Experimental Economics, 15(1), 24-43.

344. Deck, C., \& Nikiforakis, N. (2012). Perfect and imperfect real-time monitoring in a minimum-effort game. Experimental Economics, 15(1), 71-88.

345. Huber, J., \& Kirchler, M. (2012). The impact of instructions and procedure on reducing confusion and bubbles in experimental asset markets. Experimental Economics, 15(1), 89-105.

346. Goertz, J. M. (2012). Market composition and experience in common-value auctions. Experimental Economics, 15(1), 106-127.

347. Lévy-Garboua, L., Maafi, H., Masclet, D., \& Terracol, A. (2012). Risk aversion and framing effects. Experimental Economics, 15(1), 128-144.

348. Rosenboim, M., \& Shavit, T. (2012). Whose money is it anyway? Using prepaid incentives in experimental economics to create a natural environment. Experimental Economics, 15(1), 145-157.

349. Rodriguez-Lara, I., \& Moreno-Garrido, L. (2012). Self-interest and fairness: selfserving choices of justice principles. Experimental Economics, 15(1), 158-175.

350. Hyndman, K., Özbay, E. Y., Schotter, A., \& Ehrblatt, W. (2012). Belief formation: an experiment with outside observers. Experimental Economics, 15(1), 176-203.

351. Keck, S., \& Karelaia, N. (2012). Does competition foster trust? The role of tournament incentives. Experimental Economics, 15(1), 204-228.

352. Reinstein, D., \& Riener, G. (2012). Decomposing desert and tangibility effects in a charitable giving experiment. Experimental Economics, 15(1), 229-240.

353. Casari, M., \& Luini, L. (2012). Peer punishment in teams: expressive or instrumental choice?. Experimental Economics, 15(2), 241-259.

354. Norton, D. A., \& Isaac, R. M. (2012). Experts with a conflict of interest: a source of ambiguity?. Experimental economics, 15(2), 260-277.

355. Cabrales, A., Nagel, R., \& Mora, J. V. R. (2012). It is Hobbes, not Rousseau: an experiment on voting and redistribution. Experimental Economics, 15(2), 278-308.

356. Cramton, P., Filiz-Ozbay, E., Ozbay, E. Y., \& Sujarittanonta, P. (2012). Discrete clock auctions: an experimental study. Experimental Economics, 15(2), 309-322.

357. Ziegelmeyer, A., Schmelz, K., \& Ploner, M. (2012). Hidden costs of control: four repetitions and an extension. Experimental Economics, 15(2), 323-340. 
358. Cheung, S. L., \& Palan, S. (2012). Two heads are less bubbly than one: team decision-making in an experimental asset market. Experimental Economics, 15(3), 373-397.

359. Greiner, B., \& Güth, W. (2012). Social communication and discrimination: a video experiment. Experimental Economics, 15(3), 398-417.

360. Baltussen, G., Post, G. T., Van Den Assem, M. J., \& Wakker, P. P. (2012). Random incentive systems in a dynamic choice experiment. Experimental Economics, 15(3), 418-443.

361. Dickinson, D. L., \& McElroy, T. (2012). Circadian effects on strategic reasoning. Experimental Economics, 15(3), 444-459.

362. Dannenberg, A., Riechmann, T., Sturm, B., \& Vogt, C. (2012). Inequality aversion and the house money effect. Experimental Economics, 15(3), 460-484.

363. Gürerk, Ö., \& Selten, R. (2012). The effect of payoff tables on experimental oligopoly behavior. Experimental Economics, 15(3), 499-509.

364. Pearson, M., \& Schipper, B. C. (2012). The visible hand: finger ratio (2D: 4D) and competitive bidding. Experimental Economics, 15(3), 510-529.

365. Cobo-Reyes, R., \& Jiménez, N. (2012). The dark side of friendship: ‘envy’. Experimental Economics, 15(4), 547-570.

366. Aimone, J. A., \& Houser, D. (2012). What you don't know won't hurt you: a laboratory analysis of betrayal aversion. Experimental Economics, 15(4), 571-588.

367. Ong, Q., Riyanto, Y. E., \& Sheffrin, S. M. (2012). How does voice matter? Evidence from the ultimatum game. Experimental Economics, 15(4), 604-621.

368. Danz, D. N., Fehr, D., \& Kübler, D. (2012). Information and beliefs in a repeated normal-form game. Experimental Economics, 15(4), 622-640.

369. Buser, T., \& Peter, N. (2012). Multitasking. Experimental Economics, 15(4), 641655.

370. Scheffel, T., Ziegler, G., \& Bichler, M. (2012). On the impact of package selection in combinatorial auctions: an experimental study in the context of spectrum auction design. Experimental Economics, 15(4), 667-692.

371. Levati, M. V., Qiu, J., \& Mahagaonkar, P. (2012). Testing the Modigliani-Miller theorem directly in the lab. Experimental Economics, 15(4), 693-716.

372. Klijn, F., Pais, J., \& Vorsatz, M. (2013). Preference intensities and risk aversion in school choice: A laboratory experiment. Experimental Economics, 16(1), 1-22.

373. Feri, F., Gantner, A., Höchtl, W., \& Sausgruber, R. (2013). The pivotal mechanism revisited: some evidence on group manipulation. Experimental Economics, 16(1), 23-51.

374. Goeree, J. K., Offerman, T., \& Sloof, R. (2013). Demand reduction and preemptive bidding in multi-unit license auctions. Experimental Economics, 16(1), 52-87.

375. Hortala-Vallve, R., Llorente-Saguer, A., \& Nagel, R. (2013). The role of information in different bargaining protocols. Experimental Economics, 16(1), 88113.

376. Sherstyuk, K., Tarui, N., \& Saijo, T. (2013). Payment schemes in infinite-horizon experimental games. Experimental Economics, 16(1), 125-153.

377. Jakiela, P. (2013). Equity vs. efficiency vs. self-interest: on the use of dictator games to measure distributional preferences. Experimental Economics, 16(2), 208221.

378. López-Pérez, R., \& Spiegelman, E. (2013). Why do people tell the truth? Experimental evidence for pure lie aversion. Experimental Economics, 16(3), 233247.

379. Li, K. K. (2013). Asymmetric memory recall of positive and negative events in social interactions. Experimental Economics, 16(3), 248-262. 
380. Filippin, A., \& Guala, F. (2013). Costless discrimination and unequal achievements in an experimental tournament. Experimental economics, 16(3), 285-305.

381. Oexl, R., \& Grossman, Z. J. (2013). Shifting the blame to a powerless intermediary. Experimental Economics, 16(3), 306-312.

382. Shurchkov, O. (2013). Coordination and learning in dynamic global games: experimental evidence. Experimental Economics, 16(3), 313-334.

383. Cleave, B. L., Nikiforakis, N., \& Slonim, R. (2013). Is there selection bias in laboratory experiments? The case of social and risk preferences. Experimental Economics, 16(3), 372-382.

384. Smith, A. (2013). Estimating the causal effect of beliefs on contributions in repeated public good games. Experimental Economics, 16(3), 414-425.

385. Cabrera, S., Fatás, E., Lacomba, J. A., \& Neugebauer, T. (2013). Splitting leagues: promotion and demotion in contribution-based regrouping experiments. Experimental Economics, 16(3), 426-441.

386. Cooper, D. J., \& Lightle, J. P. (2013). The gift of advice: Communication in a bilateral gift exchange game. Experimental Economics, 16(4), 443-477.

387. Bayer, R. C., Renner, E., \& Sausgruber, R. (2013). Confusion and learning in the voluntary contributions game. Experimental Economics, 16(4), 478-496.

388. Cherry, T. L., Cotten, S. J., \& Kroll, S. (2013). Heterogeneity, coordination and the provision of best-shot public goods. Experimental Economics, 16(4), 497-510.

389. Bichler, M., Shabalin, P., \& Wolf, J. (2013). Do core-selecting combinatorial clock auctions always lead to high efficiency? An experimental analysis of spectrum auction designs. Experimental Economics, 16(4), 511-545.

390. Anbarci, N., \& Feltovich, N. (2013). How sensitive are bargaining outcomes to changes in disagreement payoffs?. Experimental Economics, 16(4), 560-596.

391. Deck, C., Servátka, M., \& Tucker, S. (2013). An examination of the effect of messages on cooperation under double-blind and single-blind payoff procedures. Experimental Economics, 16(4), 597-607.

392. Nikiforakis, N., \& Mitchell, H. (2014). Mixing the carrots with the sticks: Third party punishment and reward. Experimental Economics, 17(1), 1-23.

393. Cárdenas, J. C., De Roux, N., Jaramillo, C. R., \& Martinez, L. R. (2014). Is it my money or not? An experiment on risk aversion and the house-money effect. Experimental Economics, 17(1), 47-60.

394. Cornand, C., \& Heinemann, F. (2014). Measuring agents' reaction to private and public information in games with strategic complementarities. Experimental Economics, 17(1), 61-77.

395. Drugov, M., Hamman, J., \& Serra, D. (2014). Intermediaries in corruption: an experiment. Experimental Economics, 17(1), 78-99.

396. Aycinena, D., Baltaduonis, R., \& Rentschler, L. (2014). Valuation structure in firstprice and least-revenue auctions: an experimental investigation. Experimental Economics, 17(1), 100-128.

397. Cheung, S. L. (2014). New insights into conditional cooperation and punishment from a strategy method experiment. Experimental Economics, 17(1), 129-153.

398. de Groot Ruiz, A., Offerman, T., \& Onderstal, S. (2014). For those about to talk we salute you: an experimental study of credible deviations and ACDC. Experimental Economics, 17(2), 173-199.

399. Filiz-Ozbay, E., \& Ozbay, E. Y. (2014). Effect of an audience in public goods provision. Experimental Economics, 17(2), 200-214.

400. Tsutsui, K., \& Zizzo, D. J. (2014). Group status, minorities and trust. Experimental Economics, 17(2), 215-244. 
401. Brookins, P., \& Ryvkin, D. (2014). An experimental study of bidding in contests of incomplete information. Experimental Economics, 17(2), 245-261.

402. Mak, V., \& Zwick, R. (2014). Experimenting and learning with localized direct communication. Experimental Economics, 17(2), 262-284.

403. Zhang, B., Li, C., De Silva, H., Bednarik, P., \& Sigmund, K. (2014). The evolution of sanctioning institutions: an experimental approach to the social contract. Experimental Economics, 17(2), 285-303.

404. Stöckl, T. (2014). Price efficiency and trading behavior in limit order markets with competing insiders. Experimental Economics, 17(2), 314-334.

405. Chuah, S. H., Hoffmann, R., \& Larner, J. (2014). Elicitation effects in a multi-stage bargaining experiment. Experimental Economics, 17(2), 335-345.

406. Koppel, H., \& Regner, T. (2014). Corporate Social Responsibility in the work place. Experimental Economics, 17(3), 347-370.

407. Ruud, P. A., Schunk, D., \& Winter, J. K. (2014). Uncertainty causes rounding: an experimental study. Experimental Economics, 17(3), 391-413.

408. Goeree, J. K., \& Zhang, J. (2014). Communication \& competition. Experimental Economics, 17(3), 421-438.

409. Jacobson, S., \& Petrie, R. (2014). Favor trading in public good provision. Experimental Economics, 17(3), 439-460.

410. Dechenaux, E., Mago, S. D., \& Razzolini, L. (2014). Traffic congestion: an experimental study of the Downs-Thomson paradox. Experimental economics, 17(3), 461-487.

411. Korenok, O., Millner, E. L., \& Razzolini, L. (2014). Taking, giving, and impure altruism in dictator games. Experimental Economics, 17(3), 488-500.

412. Chen, Y., Jeon, G. Y., \& Kim, Y. M. (2014). A day without a search engine: An experimental study of online and offline searches. Experimental Economics, 17(4), 512-536.

413. Butler, D., Isoni, A., Loomes, G., \& Tsutsui, K. (2014). Beyond choice: investigating the sensitivity and validity of measures of strength of preference. Experimental Economics, 17(4), 537-563.

414. Agranov, M., Bisin, A., \& Schotter, A. (2014). An experimental study of the impact of competition for other people's money: the portfolio manager market. Experimental Economics, 17(4), 564-585.

415. Reiß, J. P., \& Wolff, I. (2014). Incentive effects of funding contracts: an experiment. Experimental Economics, 17(4), 586-614.

416. Kvaløy, O., \& Luzuriaga, M. (2014). Playing the trust game with other people's money. Experimental Economics, 17(4), 615-630.

417. Botelho, A., Dinar, A., Pinto, L. M. C., \& Rapoport, A. (2014). Time and uncertainty in resource dilemmas: equilibrium solutions and experimental results. Experimental economics, 17(4), 649-672.

418. Samek, A. S., \& Sheremeta, R. M. (2014). Recognizing contributors: an experiment on public goods. Experimental Economics, 17(4), 673-690.

419. Buchanan, J. A., \& Wilson, B. J. (2014). An experiment on protecting intellectual property. Experimental Economics, 17(4), 691-716.

420. Cojoc, D., \& Stoian, A. (2014). Dishonesty and charitable behavior. Experimental Economics, 17(4), 717-732.

421. Nosenzo, D., Quercia, S., \& Sefton, M. (2015). Cooperation in small groups: The effect of group size. Experimental Economics, 18(1), 4-14.

422. Leibbrandt, A., Ramalingam, A., Sääksvuori, L., \& Walker, J. M. (2015). Incomplete punishment networks in public goods games: experimental evidence. Experimental Economics, 18(1), 15-37. 
423. Kamei, K., Putterman, L., \& Tyran, J. R. (2015). State or nature? Endogenous formal versus informal sanctions in the voluntary provision of public goods. Experimental Economics, 18(1), 38-65.

424. Cason, T. N., \& Gangadharan, L. (2015). Promoting cooperation in nonlinear social dilemmas through peer punishment. Experimental Economics, 18(1), 66-88.

425. Cherry, J., Salant, S., \& Uler, N. (2015). Experimental departures from self-interest when competing partnerships share output. Experimental Economics, 18(1), 89115.

426. de Oliveira, A. C., Croson, R. T., \& Eckel, C. (2015). One bad apple? Heterogeneity and information in public good provision. Experimental Economics, 18(1), 116-135.

427. Dickinson, D. L., Dutcher, E. G., \& Rodet, C. S. (2015). Observed punishment spillover effects: a laboratory investigation of behavior in a social dilemma. Experimental Economics, 18(1), 136-153.

428. Andreoni, J., \& Gee, L. K. (2015). Gunning for efficiency with third party enforcement in threshold public goods. Experimental Economics, 18(1), 154-171.

429. Brown, A. L., \& Cohen, G. (2015). Does anonymity affect the willingness to accept and willingness to pay gap? A generalization of Plott and Zeiler. Experimental Economics, 18(2), 173-184.

430. Roux, C., \& Thöni, C. (2015). Do control questions influence behavior in experiments?. Experimental Economics, 18(2), 185-194.

431. Cox, J. C., Sadiraj, V., \& Schmidt, U. (2015). Paradoxes and mechanisms for choice under risk. Experimental Economics, 18(2), 215-250.

432. Corgnet, B., Hernán-González, R., \& Schniter, E. (2015). Why real leisure really matters: Incentive effects on real effort in the laboratory. Experimental Economics, 18(2), 284-301.

433. Stöckl, T., Huber, J., \& Kirchler, M. (2015). Multi-period experimental asset markets with distinct fundamental value regimes. Experimental Economics, 18(2), 314-334.

434. Gretschko, V., \& Rajko, A. (2015). Excess information acquisition in auctions. Experimental Economics, 18(3), 335-355.

435. Kartal, M. (2015). Laboratory elections with endogenous turnout: proportional representation versus majoritarian rule. Experimental Economics, 18(3), 366-384.

436. Wibral, M. (2015). Identity changes and the efficiency of reputation systems. Experimental Economics, 18(3), 408-431.

437. Khadjavi, M., \& Lange, A. (2015). Doing good or doing harm: experimental evidence on giving and taking in public good games. Experimental Economics, 18(3), 432-441.

438. Noussair, C. N., \& Stoop, J. (2015). Time as a medium of reward in three social preference experiments. Experimental Economics, 18(3), 442-456.

439. Harris, D., Herrmann, B., Kontoleon, A., \& Newton, J. (2015). Is it a norm to favour your own group?. Experimental Economics, 18(3), 491-521.

440. Robbett, A. (2015). Voting with hands and feet: the requirements for optimal group formation. Experimental Economics, 18(3), 522-541.

441. Bonein, A., \& Denant-Boèmont, L. (2015). Self-control, commitment and peer pressure: a laboratory experiment. Experimental Economics, 18(4), 543-568.

442. Neri, C. (2015). Eliciting beliefs in continuous-choice games: a double auction experiment. Experimental Economics, 18(4), 569-608.

443. Giamattei, M., \& Lambsdorff, J. G. (2015). Balancing the current account: experimental evidence on underconsumption. Experimental Economics, 18(4), 670696. 
444. Tergiman, C. (2015). Institution design and public good provision: an experimental study of the vote of confidence procedure. Experimental Economics, 18(4), 697717.

445. Fielding, D., \& Knowles, S. (2015). Can you spare some change for charity? Experimental evidence on verbal cues and loose change effects in a Dictator Game. Experimental Economics, 18(4), 718-730.

446. Offerman, T., \& Palley, A. B. (2016). Lossed in translation: an off-the-shelf method to recover probabilistic beliefs from loss-averse agents. Experimental economics, 19(1), 1-30.

447. Kalayc1, K., \& Serra-Garcia, M. (2016). Complexity and biases. Experimental Economics, 19(1), 31-50.

448. Kloosterman, A. (2016). Directed search with heterogeneous firms: an experimental study. Experimental Economics, 19(1), 51-66.

449. Davis, D., Ivanov, A., \& Korenok, O. (2016). Individual characteristics and behavior in repeated games: an experimental study. Experimental Economics, 19(1), 67-99.

450. Di Bartolomeo, G., \& Papa, S. (2016). Trust and reciprocity: extensions and robustness of triadic design. Experimental Economics, 19(1), 100-115.

451. Lien, J. W., Zheng, J., \& Zhong, X. (2016). Preference submission timing in school choice matching: testing fairness and efficiency in the laboratory. Experimental Economics, 19(1), 116-150.

452. Mengel, F., Tsakas, E., \& Vostroknutov, A. (2016). Past experience of uncertainty affects risk aversion. Experimental Economics, 19(1), 151-176.

453. Devetag, G., Di Guida, S., \& Polonio, L. (2016). An eye-tracking study of featurebased choice in one-shot games. Experimental Economics, 19(1), 177-201.

454. Kamijo, Y., Ozono, H., \& Shimizu, K. (2016). Overcoming coordination failure using a mechanism based on gradualism and endogeneity. Experimental Economics, 19(1), 202-217.

455. Thoma, C. (2016). Under-versus overconfidence: an experiment on how others perceive a biased self-assessment. Experimental Economics, 19(1), 218-239.

456. Banerjee, R. (2016). On the interpretation of bribery in a laboratory corruption game: moral frames and social norms. Experimental Economics, 19(1), 240-267.

457. Erat, S., \& Gneezy, U. (2016). Incentives for creativity. Experimental Economics, 19(2), 269-280.

458. Meissner, T. (2016). Intertemporal consumption and debt aversion: an experimental study. Experimental Economics, 19(2), 281-298.

459. Kalayc1, K. (2016). Confusopoly: competition and obfuscation in markets. Experimental Economics, 19(2), 299-316.

460. Duffy, J., \& Lafky, J. (2016). Birth, death and public good provision. Experimental Economics, 19(2), 317-341.

461. Feldhaus, C., \& Stauf, J. (2016). More than words: the effects of cheap talk in a volunteer's dilemma. Experimental Economics, 19(2), 342-359.

462. Tyszler, M., \& Schram, A. (2016). Information and strategic voting. Experimental economics, 19(2), 360-381.

463. Ismayilov, H., \& Potters, J. (2016). Why do promises affect trustworthiness, or do they?. Experimental Economics, 19(2), 382-393.

464. Huber, J., Kirchler, M., \& Stöckl, T. (2016). The influence of investment experience on market prices: laboratory evidence. Experimental Economics, 19(2), 394-411. 
465. Charness, G., Cobo-Reyes, R., Lacomba, J. A., Lagos, F., \& Pérez, J. M. (2016). Social comparisons in wage delegation: Experimental evidence. Experimental Economics, 19(2), 433-459.

466. Montinari, N., Nicolò, A., \& Oexl, R. (2016). The gift of being chosen. Experimental Economics, 19(2), 460-479.

467. Riyanto, Y. E., \& Zhang, J. (2016). Putting a price tag on others' perceptions of us. Experimental Economics, 19(2), 480-499.

468. Yamakawa, T., Okano, Y., \& Saijo, T. (2016). Detecting motives for cooperation in public goods experiments. Experimental Economics, 19(2), 500-512.

469. Bolton, G., \& Werner, P. (2016). The influence of potential on wages and effort. Experimental Economics, 19(3), 535-561.

470. Hauge, K. E., Brekke, K. A., Johansson, L. O., Johansson-Stenman, O., \& Svedsäter, H. (2016). Keeping others in our mind or in our heart? Distribution games under cognitive load. Experimental Economics, 19(3), 562-576.

471. Hey, J. D., \& Di Cagno, D. (2016). Does money impede convergence? Experimental Economics, 19(3), 595-612.

472. Crosetto, P., \& Filippin, A. (2016). A theoretical and experimental appraisal of four risk elicitation methods. Experimental Economics, 19(3), 613-641.

473. Ifcher, J., \& Zarghamee, H. (2016). Pricing competition: a new laboratory measure of gender differences in the willingness to compete. Experimental Economics, 19(3), 642-662.

474. Fehr, D., \& Huck, S. (2016). Who knows it is a game? On strategic awareness and cognitive ability. Experimental Economics, 19(4), 713-726.

475. Casari, M., Zhang, J., \& Jackson, C. (2016). Same process, different outcomes: group performance in an acquiring a company experiment. Experimental Economics, 19(4), 764-791.

476. Brandts, J., Rott, C., \& Solà, C. (2016). Not just like starting over-Leadership and revivification of cooperation in groups. Experimental economics, 19(4), 792-818.

477. Grimalda, G., Kar, A., \& Proto, E. (2016). Procedural fairness in lotteries assigning initial roles in a dynamic setting. Experimental Economics, 19(4), 819-841.

478. Frackenpohl, G., Hillenbrand, A., \& Kube, S. (2016). Leadership effectiveness and institutional frames. Experimental Economics, 19(4), 842-863.

479. Olivola, C. Y., \& Wang, S. W. (2016). Patience auctions: The impact of time vs. money bidding on elicited discount rates. Experimental Economics, 19(4), 864-885.

480. Aguiar-Conraria, L., Magalhães, P. C., \& Vanberg, C. A. (2016). Experimental evidence that quorum rules discourage turnout and promote election boycotts. Experimental Economics, 19(4), 886-909.

481. Cox, J. C., Servátka, M., \& Vadovič, R. (2017). Status quo effects in fairness games: reciprocal responses to acts of commission versus acts of omission. Experimental Economics, 20(1), 1-18.

482. Belot, M., \& Van de Ven, J. (2017). How private is private information? The ability to spot deception in an economic game. Experimental Economics, 20(1), 19-43.

483. Kocher, M. G., Martinsson, P., Myrseth, K. O. R., \& Wollbrant, C. E. (2017). Strong, bold, and kind: Self-control and cooperation in social dilemmas. Experimental Economics, 20(1), 44-69.

484. Corazzini, L., Galavotti, S., Sausgruber, R., \& Valbonesi, P. (2017). Allotment in first-price auctions: an experimental investigation. Experimental Economics, 20(1), 70-99.

485. Gioia, F. (2017). Peer effects on risk behaviour: the importance of group identity. Experimental Economics, 20(1), 100-129. 
486. Alevy, J. E., \& Price, M. K. (2017). Advice in the marketplace: a laboratory study. Experimental Economics, 20(1), 156-180.

487. Denant-Boemont, L., Diecidue, E., \& l'Haridon, O. (2017). Patience and time consistency in collective decisions. Experimental Economics, 20(1), 181-208.

488. Cahlíková, J., \& Cingl, L. (2017). Risk preferences under acute stress. Experimental Economics, 20(1), 209-236.

489. Bosworth, S. J. (2017). The importance of higher-order beliefs to successful coordination. Experimental Economics, 20(1), 237-258.

490. Bruner, D. M. (2017). Does decision error decrease with risk aversion?. Experimental Economics, 20(1), 259-273.

491. Fréchette, G. R., \& Yuksel, S. (2017). Infinitely repeated games in the laboratory: Four perspectives on discounting and random termination. Experimental Economics, 20(2), 279-308.

492. Pan, X., \& Houser, D. (2017). Social approval, competition and cooperation. Experimental Economics, 20(2), 309-332.

493. Cardella, E., \& Kitchens, C. (2017). The impact of award uncertainty on settlement negotiations. Experimental Economics, 20(2), 333-367.

494. Blume, A., Kriss, P. H., \& Weber, R. A. (2017). Pre-play communication with forgone costly messages: experimental evidence on forward induction.

Experimental Economics, 20(2), 368-395.

495. Chen, J., \& Houser, D. (2017). Promises and lies: can observers detect deception in written messages. Experimental economics, 20(2), 396-419.

496. Ryvkin, D., \& Semykina, A. (2017). An experimental study of democracy breakdown, income and inequality. Experimental Economics, 20(2), 420-447.

497. Baghestanian, S., Gortner, P., \& Massenot, B. (2017). Compensation schemes, liquidity provision, and asset prices: an experimental analysis. Experimental Economics, 20(2), 481-505.

498. Buser, T., Dreber, A., \& Mollerstrom, J. (2017). The impact of stress on tournament entry. Experimental economics, 20(2), 506-530.

499. Andersson, O., Miettinen, T., Hytönen, K., Johannesson, M., \& Stephan, U. (2017). Subliminal influence on generosity. Experimental Economics, 20(3), 531-555.

500. Sloof, R., \& von Siemens, F. A. (2017). Illusion of Control and the Pursuit of Authority. Experimental Economics, 20(3), 556-573.

501. Roelofs, M. R., Østbye, S. E., \& Heen, E. E. (2017). Asymmetric firms, technology sharing and R\&D investment. Experimental Economics, 20(3), 574-600.

502. Bosch-Rosa, C., Aperjis, C., Friedman, D., \& Huberman, B. A. (2017). Intolerable nuisances: some laboratory evidence on survivor curve shapes. Experimental Economics, 20(3), 601-621.

503. Eriksson, T., Mao, L., \& Villeval, M. C. (2017). Saving face and group identity. Experimental Economics, 20(3), 622-647.

504. Jian, L., Li, Z., \& Liu, T. X. (2017). Simultaneous versus sequential all-pay auctions: an experimental study. Experimental Economics, 20(3), 648-669.

505. Guillen, P., \& Hakimov, R. (2017). Not quite the best response: Truth-telling, strategy-proof matching, and the manipulation of others. Experimental Economics, 20(3), 670-686.

506. Fenig, G., \& Petersen, L. (2017). Distributing scarce jobs and output: experimental evidence on the dynamic effects of rationing. Experimental Economics, 20(3), 707735.

507. Georganas, S., Levin, D., \& McGee, P. (2017). Optimistic irrationality and overbidding in private value auctions. Experimental Economics, 20(4), 772-792. 
508. Blanco, E., Haller, T., \& Walker, J. M. (2017). Externalities in appropriation: responses to probabilistic losses. Experimental Economics, 20(4), 793-808.

509. Hernandez-Lagos, P., Minor, D., \& Sisak, D. (2017). Do people who care about others cooperate more? Experimental evidence from relative incentive pay. Experimental Economics, 20(4), 809-835.

510. Corcos, A., Pannequin, F., \& Montmarquette, C. (2017). Leaving the market or reducing the coverage? A model-based experimental analysis of the demand for insurance. Experimental Economics, 20(4), 836-859.

511. Kvaløy, O., Luzuriaga, M., \& Olsen, T. E. (2017). A trust game in loss domain. Experimental Economics, 20(4), 860-877.

512. Koppel, L., Andersson, D., Posadzy, K., Västfjäll, D., \& Tinghög, G. (2017). The effect of acute pain on risky and intertemporal choice. Experimental economics, 20(4), 878-893.

513. Gee, L. K., Migueis, M., \& Parsa, S. (2017). Redistributive choices and increasing income inequality: experimental evidence for income as a signal of deservingness. Experimental Economics, 20(4), 894-923.

514. Hong, F., \& Zhao, X. (2017). The emergence of language differences in artificial codes. Experimental Economics, 20(4), 924-945.

515. Cason, T. N., Sheremeta, R. M., \& Zhang, J. (2017). Asymmetric and endogenous within-group communication in competitive coordination games. Experimental Economics, 20(4), 946-972.

516. Ausubel, L. M., Burkett, J. E., \& Filiz-Ozbay, E. (2017). An experiment on auctions with endogenous budget constraints. Experimental Economics, 20(4), 9731006.

517. Engler, Y., Kerschbamer, R., \& Page, L. (2018). Why did he do that? Using counterfactuals to study the effect of intentions in extensive form games. Experimental Economics, 21(1), 1-26.

518. Evdokimov, P., \& Garfagnini, U. (2018). Third-party manipulation of conflict: an experiment. Experimental Economics, 21(1), 27-49.

519. Charness, G., Rustichini, A., \& Van de Ven, J. (2018). Self-confidence and strategic behavior. Experimental Economics, 21(1), 72-98.

520. Bosch-Rosa, C., Meissner, T., \& Bosch-Domènech, A. (2018). Cognitive bubbles. Experimental Economics, 21(1), 132-153.

521. Kleinlercher, D., \& Stöckl, T. (2018). On the provision of incentives in finance experiments. Experimental Economics, 21(1), 154-179.

522. Kesternich, M., Lange, A., \& Sturm, B. (2018). On the performance of rule-based contribution schemes under endowment heterogeneity. Experimental Economics, 21(1), 180-204.

523. Baillon, A., Schlesinger, H., \& van de Kuilen, G. (2018). Measuring higher order ambiguity preferences. Experimental Economics, 21(2), 233-256.

524. Szembrot, N. (2018). Experimental study of cursed equilibrium in a signaling game. Experimental Economics, 21(2), 257-291.

525. Rubin, J., Samek, A., \& Sheremeta, R. M. (2018). Loss aversion and the quantityquality tradeoff. Experimental Economics, 21(2), 292-315.

526. Bellemare, C., Sebald, A., \& Suetens, S. (2018). Heterogeneous guilt sensitivities and incentive effects. Experimental Economics, 21(2), 316-336.

527. Leibbrandt, A., \& Lynham, J. (2018). Does the paradox of plenty exist? Experimental evidence on the curse of resource abundance. Experimental Economics, 21(2), 337-354.

528. Heinrich, T., \& Mayrhofer, T. (2018). Higher-order risk preferences in social settings. Experimental economics, 21(2), 434-456. 
529. Cooper, D. J., \& Van Huyck, J. (2018). Coordination and transfer. Experimental Economics, 21(3), 487-512.

530. Van Huyck, J., \& Stahl, D. O. (2018). Conditional behavior and learning in similar stag hunt games. Experimental Economics, 21(3), 513-526.

531. Van Huyck, J., Viriyavipart, A., \& Brown, A. L. (2018). When less information is good enough: experiments with global stag hunt games. Experimental Economics, 21(3), 527-548.

532. Leng, A., Friesen, L., Kalayci, K., \& Man, P. (2018). A minimum effort coordination game experiment in continuous time. Experimental Economics, 21(3), 549-572.

533. Duffy, J., \& Fehr, D. (2018). Equilibrium selection in similar repeated games: Experimental evidence on the role of precedents. Experimental Economics, 21(3), 573-600.

534. Kurz, V., Orland, A., \& Posadzy, K. (2018). Fairness versus efficiency: how procedural fairness concerns affect coordination. Experimental Economics, 21(3), 601-626.

535. Jacquemet, N., Luchini, S., Shogren, J. F., \& Zylbersztejn, A. (2018). Coordination with communication under oath. Experimental Economics, 21(3), 627-649.

536. Filiz-Ozbay, E., Ham, J. C., Kagel, J. H., \& Ozbay, E. Y. (2018). The role of cognitive ability and personality traits for men and women in gift exchange outcomes. Experimental Economics, 21(3), 650-672.

537. Camera, G., \& Casari, M. (2018). Monitoring institutions in indefinitely repeated games. Experimental Economics, 21(3), 673-691.

538. Arifovic, J., \& Ledyard, J. (2018). Learning to alternate. Experimental Economics, 21(3), 692-721.

539. Zhou, W., \& Hey, J. (2018). Context matters. Experimental economics, 21(4), 723756.

540. Regner, T. (2018). Reciprocity under moral wiggle room: Is it a preference or a constraint?. Experimental Economics, 21(4), 779-792.

541. He, T. S., \& Hong, F. (2018). Risk breeds risk aversion. Experimental Economics, 21(4), 815-835.

542. Chen, J. I., \& Kamei, K. (2018). Disapproval aversion or inflated inequity acceptance? The impact of expressing emotions in ultimatum bargaining. Experimental economics, 21(4), 836-857.

543. Wu, J. (2018). Indirect higher order beliefs and cooperation. Experimental Economics, 21(4), 858-876.

544. Clingingsmith, D., \& Sheremeta, R. M. (2018). Status and the demand for visible goods: Experimental evidence on conspicuous consumption. Experimental Economics, 21(4), 877-904.

545. Aycinena, D., \& Rentschler, L. (2018). Auctions with endogenous participation and an uncertain number of bidders: experimental evidence. Experimental Economics, 21(4), 924-949.

\section{Journal of the European Economic Association}

546. Goeree, J. K., Plott, C. R., \& Wooders, J. (2004). Bidders' choice auctions: Raising revenues through the right to choose. Journal of the European Economic Association, 2(2-3), 504-515.

547. Gächter, S., \& Thöni, C. (2005). Social learning and voluntary cooperation among like-minded people. Journal of the European Economic Association, 3(2-3), 303314. 
548. Bohnet, I., Harmgart, H., \& Tyran, J. R. (2005). Learning trust. Journal of the European Economic Association, 3(2-3), 322-329.

549. Brandts, J., \& Cooper, D. J. (2007). It's what you say, not what you pay: An experimental study of manager-employee relationships in overcoming coordination failure. Journal of the European Economic Association, 5(6), 1223-1268.

550. Fehr, E., Zehnder, C., \& Hart, O. (2009). Contracts, reference points, and competition-behavioral effects of the fundamental transformation. Journal of the European Economic Association, 7(2-3), 561-572.

551. Cooper, D. J., \& Kagel, J. H. (2009). The role of context and team play in crossgame learning. Journal of the European Economic Association, 7(5), 1101-1139.

552. Goeree, J. K., Palmer, K., Holt, C. A., Shobe, W., \& Burtraw, D. (2010). An experimental study of auctions versus grandfathering to assign pollution permits. Journal of the European Economic Association, 8(2-3), 514-525.

553. Müller, W., \& Schotter, A. (2010). Workaholics and dropouts in organizations. Journal of the European Economic Association, 8(4), 717-743.

554. Abeler, J., Altmann, S., Kube, S., \& Wibral, M. (2010). Gift exchange and workers' fairness concerns: when equality is unfair. Journal of the European Economic Association, 8(6), 1299-1324.

555. Ericson, K. M. M. (2011). Forgetting we forget: Overconfidence and memory. Journal of the European Economic Association, 9(1), 43-60.

556. Grosse, S., Putterman, L., \& Rockenbach, B. (2011). Monitoring in teams: using laboratory experiments to study a theory of the firm. Journal of the European Economic Association, 9(4), 785-816.

557. Hyndman, K., Ozbay, E. Y., Schotter, A., \& Ehrblatt, W. Z. E. (2012). Convergence: an experimental study of teaching and learning in repeated games. Journal of the European Economic Association, 10(3), 573-604.

558. Shurchkov, O. (2012). Under pressure: gender differences in output quality and quantity under competition and time constraints. Journal of the European Economic Association, 10(5), 1189-1213.

559. Krupka, E. L., \& Weber, R. A. (2013). Identifying social norms using coordination games: Why does dictator game sharing vary?. Journal of the European Economic Association, 11(3), 495-524.

560. Fischbacher, U., \& Föllmi-Heusi, F. (2013). Lies in disguise-an experimental study on cheating. Journal of the European Economic Association, 11(3), 525-547.

561. Gächter, S., Nosenzo, D., \& Sefton, M. (2013). Peer effects in pro-social behavior: Social norms or social preferences?. Journal of the European Economic Association, 11(3), 548-573.

562. Cappelen, A. W., Moene, K. O., Sørensen, E. Ø., \& Tungodden, B. (2013). Needs versus entitlements - an international fairness experiment. Journal of the European Economic Association, 11(3), 574-598.

563. Bartling, B., Fehr, E., \& Schmidt, K. M. (2013). Use and abuse of authority: a behavioural foundation of the employment relation. Journal of the European Economic Association, 11(4), 711-742.

564. Serra-Garcia, M., Van Damme, E., \& Potters, J. (2013). Lying about what you know or about what you do?. Journal of the European Economic Association, 11(5), 1204-1229.

565. Choi, S., \& Lee, J. (2014). Communication, coordination, and networks. Journal of the European Economic Association, 12(1), 223-247.

566. Durante, R., Putterman, L., \& Van der Weele, J. (2014). Preferences for redistribution and perception of fairness: An experimental study. Journal of the European Economic Association, 12(4), 1059-1086. 
567. Baeriswyl, R., \& Cornand, C. (2014). Reducing overreaction to central banks' disclosures: theory and experiment. Journal of the European Economic Association, 12(4), 1087-1126.

568. Heffetz, O., \& List, J. A. (2014). Is the endowment effect an expectations effect?. Journal of the European Economic Association, 12(5), 1396-1422.

569. Fehr, E., Hart, O., \& Zehnder, C. (2015). How do informal agreements and revision shape contractual reference points?. Journal of the European Economic Association, 13(1), 1-28.

570. Bartling, B., \& Schmidt, K. M. (2015). Reference points, social norms, and fairness in contract renegotiations. Journal of the European Economic Association, 13(1), 98-129.

571. Benoît, J. P., Dubra, J., \& Moore, D. A. (2015). Does the better-than-average effect show that people are overconfident?: Two experiments. Journal of the European Economic Association, 13(2), 293-329.

572. Kimbrough, E. O., \& Vostroknutov, A. (2016). Norms make preferences social. Journal of the European Economic Association, 14(3), 608-638.

573. Brandts, J., Ellman, M., \& Charness, G. (2015). Let's talk: How communication affects contract design. Journal of the European Economic Association, 14(4), 943974.

574. Grossman, Z., \& Van der Weele, J. J. (2017). Self-image and willful ignorance in social decisions. Journal of the European Economic Association, 15(1), 173-217.

575. Cappelen, A. W., Halvorsen, T., Sørensen, E. Ø., \& Tungodden, B. (2017). Facesaving or fair-minded: What motivates moral behavior?. Journal of the European Economic Association, 15(3), 540-557.

576. Dertwinkel-Kalt, M., Köhler, K., Lange, M. R., \& Wenzel, T. (2017). Demand shifts due to salience effects: Experimental evidence. Journal of the European Economic Association, 15(3), 626-653.

577. Choi, S., Galeotti, A., \& Goyal, S. (2017). Trading in networks: theory and experiments. Journal of the European Economic Association, 15(4), 784-817.

578. Gneezy, U., Goette, L., Sprenger, C., \& Zimmermann, F. (2017). The limits of expectations-based reference dependence. Journal of the European Economic Association, 15(4), 861-876.

579. Barrett, S., \& Dannenberg, A. (2017). Tipping versus cooperating to supply a public good. Journal of the European Economic Association, 15(4), 910-941.

580. d'Adda, G., Darai, D., Pavanini, N., \& Weber, R. A. (2017). Do leaders affect ethical conduct?. Journal of the European Economic Association, 15(6), 1177 1213.

581. Aghion, P., Fehr, E., Holden, R., \& Wilkening, T. (2018). The Role of Bounded Rationality and Imperfect Information in Subgame Perfect Implementation-An Empirical Investigation. Journal of the European Economic Association, 16(1), 232-274.

582. Herz, H., \& Taubinsky, D. (2018). What makes a price fair? An experimental study of transaction experience and endogenous fairness views. Journal of the European Economic Association, 16(2), 316-352.

583. Agranov, M., Goeree, J. K., Romero, J., \& Yariv, L. (2018). What makes voters turn out: The effects of polls and beliefs. Journal of the European Economic Association, 16(3), 825-856. 